\title{
Trendrapport arbeidsmarkt technisch opgeleiden
}

Citation for published version (APA):

Matheeuwsen, A. G. M., Smits, W., \& Willems, E. J. T. A. (1994). Trendrapport arbeidsmarkt technisch opgeleiden. Researchcentrum voor Onderwijs en Arbeidsmarkt, Faculteit der Economische

Wetenschappen. ROA Reports No. 12 https://doi.org/10.26481/umarep.1994012

Document status and date:

Published: 01/01/1994

DOI:

10.26481/umarep.1994012

Document Version:

Publisher's PDF, also known as Version of record

\section{Please check the document version of this publication:}

- A submitted manuscript is the version of the article upon submission and before peer-review. There can be important differences between the submitted version and the official published version of record.

People interested in the research are advised to contact the author for the final version of the publication, or visit the DOI to the publisher's website.

- The final author version and the galley proof are versions of the publication after peer review.

- The final published version features the final layout of the paper including the volume, issue and page numbers.

Link to publication

\footnotetext{
General rights rights.

- You may freely distribute the URL identifying the publication in the public portal. please follow below link for the End User Agreement:

www.umlib.nl/taverne-license

Take down policy

If you believe that this document breaches copyright please contact us at:

repository@maastrichtuniversity.nl

providing details and we will investigate your claim.
}

Copyright and moral rights for the publications made accessible in the public portal are retained by the authors and/or other copyright owners and it is a condition of accessing publications that users recognise and abide by the legal requirements associated with these

- Users may download and print one copy of any publication from the public portal for the purpose of private study or research.

- You may not further distribute the material or use it for any profit-making activity or commercial gain

If the publication is distributed under the terms of Article $25 \mathrm{fa}$ of the Dutch Copyright Act, indicated by the "Taverne" license above, 


\section{Trendrapport arbeidsmarkt technisch opgeleiden}

ROA-R-1994/12

A.G.M. Matheeuwsen

W. Smits

E.J.T.A. Willems

Researchcentrum voor Onderwijs en Arbeidsmarkt

Faculteit der Economische Wetenschappen

Rijksuniversiteit Limburg

Maastricht, december 1994 


\section{CIP-GEGEVENS KONINKLIJKE BIBLIOTHEEK, DEN HAAG}

Matheeuwsen, A.G.M.

Trendrapport arbeidsmarkt technisch opgeleiden / A.G.M. Matheeuwsen, W. Smits, E.J.T.A. Willems. - Maastricht: Researchcentrum voor Onderwijs en Arbeidsmarkt, Faculteit der Economische Wetenschappen, Rijksuniversiteit Limburg. - (Rapport / Researchcentrum voor Onderwijs en Arbeidsmarkt, ISSN 0922-8098; ROA-R-1994/12)

Met lit. opg.

ISBN 90-5321-144-6

Trefw.: arbeidsmarkt ; technici / onderwijs en arbeidsmarkt ; Nederland. 


\section{Inhoudsopgave}

Bladzijde

\section{Voorwoord}

1 Inleiding

2 Actuele arbeidsmarktpositie van technisch opgeleiden 5

2.1 Inleiding 5

2.2 Beroepsbevolking 5

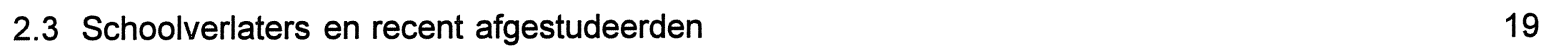

3 De toekomstige vraag naar technisch opgeleiden 37

3.1. Inleiding 37

3.2. Werkgelegenheidsontwikkeling per bedrijfssector $\quad 37$

3.3. Werkgelegenheidsontwikkeling voor de technische beroepen 38

3.4. Uitbreidingsvraag voor de technische opleidingen 41

3.5. Vervangingsvraag 44

3.6. Baanopeningen 46

4 De toekomstige instroom van technisch opgeleide schoolverlaters 49

4.1. Inleiding 49

4.2. Historische en toekomstige ontwikkeling in het aantal gediplomeerden 49

4.3. Verwachte instroom van schoolverlaters 53

5 De confrontatie van vraag en aanbod 57

5.1. Inleiding 57

5.2. Aanbodoverschotten en -tekorten op de arbeidsmarkt 57

5.3. Toekomstige arbeidsmarktsituatie $\quad 60$

5.4. Verwachte knelpunten in bedrijfssectoren $\quad 62$

6 Enkele alternatieve scenario's $\quad 65$

6.1. Inleiding 65

6.2. Het gunstige werkgelegenheidsscenario $\quad 65$

6.3. Het VUTMAO-scenario

6.4. Het stapelscenario 72

7 Conclusies en beleidsimplicaties $\quad 77$

$\begin{array}{ll}\text { Literatuur } & 85\end{array}$

$\begin{array}{ll}\text { Bijlage A Opleidingsindeling technisch onderwijs } & 87\end{array}$

Bijlage B Aanvullende tabellen bij hoofdstuk 2

Bijlage C Technische beroepsklassen 93 


\section{Voorwoord}

In dit rapport wordt een overzicht gegeven van de huidige en te verwachten ontwikkelingen op de arbeidsmarkt voor technisch opgeleiden. Het is vooral bedoeld om de arbeidsmarkt voor technici goed te kunnen 'monitoren'. Er kan derhalve met recht worden gesproken over een Trendrapport arbeidsmarkt technisch opgeleiden.

Het onderzoek sluit aan bij het door het Researchcentrum voor Onderwijs en Arbeidsmarkt (ROA) in opdracht van het Ministerie van Onderwijs, Cultuur en Wetenschappen, het Centraal Bestuur voor de Arbeidsvoorziening (CBA) en het Landelijk Dienstverlenend Centrum voor Studie- en Beroepskeuzevoorlichting (LDC) ontwikkelde informatiesysteem onderwijs-arbeidsmarkt. In dit rapport wordt de informatie echter op een gedetailleerder niveau gegenereerd en gepresenteerd. Bovendien zijn enkele scenario's voor de toekomstige arbeidsmarktpositie van technisch opgeleiden doorgerekend.

Daarnaast maakt dit onderzoek gebruik van de gegevens van de grootschalige schoolverlatersenquêtes Registratie Uitstroom en Bestemming van Schoolverlaters (RUBS) en HBO-monitor, die beide onder verantwoordelijkheid van het ROA worden uitgevoerd in opdracht van respectievelijk het LDC, het Ministerie van Onderwijs, Cultuur en Wetenschappen en het CBA (RUBS) en de HBO-Raad (HBOmonitor). In dit rapport wordt vrijwel niet ingegaan op de gehanteerde werkwijze voor het opstellen van de scenario's. Daarvoor wordt verwezen naar het werkdocument Opzet en methodiek arbeidsmarktprognoses technisch opgeleiden (Matheeuwsen, Smits, Willems en Hoevenberg, 1994).

Het onderzoek is uitgevoerd in opdracht van het Ministerie van Onderwijs, Cultuur en Wetenschappen en het Ministerie van Economische Zaken. De projectleiding van het onderzoek was in handen van drs. E.J.T.A. Willems. Verder is aan het onderzoek meegewerkt door drs. A.G.M. Matheeuwsen, drs. W. Smits en drs. J. Hoevenberg. De auteurs danken dr. L. Borghans en dr. A. de Grip die beiden een belangrijke adviesfunctie hebben vervuld en drs. R.J.P. Dekker die mede-verantwoordelijk is voor de verzameling van de gegevens. Tevens zijn zij dank verschuldigd aan drs. R.R.G. Abeln, dr. G.A. Korteweg en mvr. E.M.J.Th. Rohde, allen werkzaam bij het Ministerie van Onderwijs, Cultuur en Wetenschappen voor het doorrekenen van alternatieve scenario's met betrekking tot de uitstroom van schoolverlaters uit het voltijdonderwijs. Tot slot wordt een woord van dank gericht aan degenen die het onderzoek vanuit de opdrachtgevers hebben begeleid:
H.M. Claassen
Ministerie van Onderwijs, Cultuur en Wetenschappen (directie BVE/IE)
drs. I.M.T. Coppens
Ministerie van Onderwijs, Cultuur en Wetenschappen (directie WO)
dr.ir. F.Y. Dijkstra
Ministerie van Onderwijs, Cultuur en Wetenschappen (directie WO)
drs. C. Gorter
Ministerie van Economische Zaken (directie ATB)
drs. A. Postma
Ministerie van Onderwijs, Cultuur en Wetenschappen (directie HBO)
dr. H.H. van der Velde
Ministerie van Onderwijs, Cultuur en Wetenschappen (directie HBO) 


\section{Inleiding}

\section{Aanleiding en doelstelling}

Een tekort aan technisch geschoolde arbeidskrachten wordt door velen gezien als een bedreiging voor de technologische vernieuwing in de Nederlandse industrie. Dit zal tevens leiden tot een beperking van de economische groei in ons land, omdat een kennisintensieve technologische ontwikkeling vaak als de drijfveer voor de economie wordt gezien (zie bijvoorbeeld Ministerie van Economische Zaken, 1990). Naast deze kwantitatieve tekorten wordt ook de kwaliteit van verschillende technische opleidingen nogal eens als een probleem gezien. Het is dan ook niet vreemd dat de arbeidsmarkt voor technici al geruime tijd in de belangstelling staat.

Een adequaat preventief arbeidsmarktbeleid is van groot belang. Hiervoor is het noodzakelijk dat zowel de (toekomstige) ontwikkelingen aan de vraagzijde als aan de aanbodzijde van de arbeidsmarkt op een gedetailleerd niveau in kaart worden gebracht. Het is echter van belang om een volledig inzicht te krijgen in de arbeidsmarktpositie van technici, waarbij niet alleen wordt ingegaan op de te verwachten ontwikkeling, maar tevens enkele actuele gegevens over de arbeidsmarkt van technisch opgeleiden, alsmede enkele risico-indicatoren aan bod komen. Verder wordt door het in kaart brengen van de arbeidsmarktpositie van schoolverlaters en recent afgestudeerden een gevoelige monitor van de arbeidsmarktpositie van technisch opgeleiden verkregen.

Sinds 1986 heeft het Researchcentrum voor Onderwijs en Arbeidsmarkt een instrument ontwikkeld, dat primair tot doel heeft arbeidsmarktinformatie te verstrekken ten behoeve van de studie- en beroepskeuzevoorlichting: het informatiesysteem onderwijs-arbeidsmarkt. De gegevens van dit systeem worden daarnaast onder meer gebruikt ten behoeve van het arbeidsvoorzieningsbeleid, het onderwijsbeleid en het economische beleid in het algemeen. De belangrijkste uitkomsten worden tweejaarlijks gepubliceerd in het rapport De arbeidsmarkt naar opleiding en beroep (zie ROA, 1993).

De gegevens en de opzet van het ROA-informatiesysteem vormen een uitstekend uitgangspunt om vanuit de hierboven geformuleerde achtergrond de arbeidsmarkt voor technisch opgeleiden nader te belichten. Een belangrijke meerwaarde zou daarbij echter kunnen ontstaan wanneer de informatie op een verfijnder niveau van opleidingen zou kunnen worden gegenereerd. Uit een vorig jaar gehouden vooronderzoek is gebleken dat een dergelijke detaillering van de informatie mogelijk is (zie Willems, 1993). Daarbij is de aanbeveling gedaan om regelmatig een actueel beeld te geven van de arbeidsmarktsituatie voor technici en tevens de te verwachten ontwikkelingen daarin.

In dit eerste Trendrapport arbeidsmarkt technisch opgeleiden wordt de arbeidsmarkt voor de technische opleidingen in vele facetten belicht. In de eerste plaats is een groot aantal actuele gegevens en indicatoren, verbijzonderd naar maar liefst 24 opleidingen verdeeld over 4 niveaus, bijeengebracht. Daarnaast bestaat een belangrijk deel van het rapport uit een toekomstverkenning van de arbeidsmarkt voor technisch opgeleiden tot het jaar 2000. Daarbij wordt niet alleen een basisprognose gepresenteerd, maar tevens enkele alternatieve scenario's waarmee het effect van een veranderende algemene economische situatie of van bepaalde concrete beleidsmaatregelen in kaart kunnen worden gebracht.

Door deze opzet biedt het rapport voor tal van doelgroepen interessante informatie. Ten behoeve van de studie- en beroepskeuzevoorlichting zijn nu voor het eerst op een gedetailleerder niveau voor de technische opleidingen de perspectieven van schoolverlaters op de arbeidsmarkt in kaart gebracht. Daarmee wordt een beeld verkregen in hoeverre de perspectieven tussen de onderscheiden richtingen 
verschillen. De informatie kan echter ook vanuit het oogpunt van de vragers van arbeid worden belicht: voor werkgevers vormen zij belangrijke indicaties van de spanningen die zij op de verschillende segmenten van de arbeidsmarkt mogen verwachten. Op basis van de uitgevoerde scenario-studie wordt een beeld geschetst van de kans dat werkgevers in de nabije toekomst knelpunten gaan ondervinden bij de werving van nieuw personeel.

De gekozen aanpak van een scenario-studie biedt vooral ook voor beleidsmakers de mogelijkheid om de verwachte trends op de arbeidsmarkt voor technisch opgeleiden voor de komende jaren goed te overzien. Doordat in dit rapport tevens een relatie wordt gelegd met een groot aantal actuele gegevens en indicatoren met betrekking tot de arbeidsmarkt voor technisch opgeleiden - niet alleen voor de gehele beroepsbevolking, maar ook voor de recente intreders op deze markt - kunnen enkele beleidsimplicaties ten aanzien van de arbeidsmarkt van technisch opgeleiden onder het voetlicht worden gebracht.

De arbeidsmarktgegevens en -indicatoren voor technisch opgeleiden worden verkregen op basis van de Enquête Beroepsbevolking (EBB) van het Centraal Bureau voor de Statistiek (CBS). Deze gegevens geven een actueel beeld van de omvang en samenstelling van de arbeidsmarkt voor technisch opgeleiden. Daarbij zal voor de onderscheiden opleidingen onder meer worden ingegaan op het aantal werkenden, de man/vrouw-verhouding, de leeftijdsverdeling, de mate waarin arbeidskrachten in hun kwalificaties worden onderbenut, de conjunctuurgevoeligheid van de werkgelegenheid en de uitwijkmogelijkheden naar andere segmenten van de arbeidsmarkt.

Het is echter, zoals gezegd, ook van belang om inzicht te hebben in de arbeidsmarktpositie van schoolverlaters en recent afgestudeerden en de knelpunten die zij ondervinden bij de intrede op de arbeidsmarkt. Door het intredeproces van deze nieuwkomers op de arbeidsmarkt in kaart te brengen, wordt een gevoelige monitor verkregen van de actuele arbeidsmarktsituatie voor technisch opgeleiden. De gegevens hiervoor zijn gebaseerd op de meest recente grootschalige schoolverlatersenquêtes Registratie Uitstroom en Bestemming van Schoolverlaters (RUBS) en HBO-monitor. Daarmee wordt niet alleen een beeld gekregen van de directe kwantitatieve aansluiting tussen het technisch onderwijs en de arbeidsmarkt, in de vorm van de werkloosheid onder schoolverlaters en recent afgestudeerden, maar tevens van een aantal meer kwalitatieve aspecten, zoals de relatieve beloning, de mate van onderbenutting, enz. Ook zal worden ingegaan op de vraag in hoeverre het curriculum van de (beroeps)opleiding voldoende is toegesneden op de behoefte van de nieuwkomers op de arbeidsmarkt.

Naast dit inzicht in de actuele arbeidsmarktsituatie voor technisch opgeleiden, worden, zoals reeds is aangegeven, de verwachte toekomstige ontwikkelingen op de arbeidsmarkt voor technisch opgeleiden tot het jaar 2000 in beeld gebracht. Daarbij wordt, evenals in het informatiesysteem onderwijsarbeidsmarkt, uitgegaan van een 'stroomaanpak', waarbij een onderscheid wordt gemaakt tussen:

- de verwachte uitbreidingsvraag, die voortvloeit uit de ontwikkeling van de werkgelegenheid;

- de verwachte vervangingsvraag, vanwege onder meer (vervroegde) pensionering, (tijdelijke) terugtrekking van de arbeidsmarkt en de arbeidsmarktuitstroom naar de WAO;

- de verwachte instroom van nieuwkomers op de arbeidsmarkt;

- het aanbod van kortdurig werklozen aan het begin van de prognoseperiode. 
De verdere opzet van dit rapport is als volgt. In hoofdstuk 2 worden de actuele arbeidsmarktgegevens en -indicatoren met betrekking tot de technische opleidingen, alsmede de arbeidsmarktpositie van schoolverlaters en recent afgestudeerden van het technisch onderwijs in kaart gebracht. Hoofdstuk 3 geeft vervolgens een overzicht van de toekomstige vraagontwikkelingen op de arbeidsmarkt voor technisch opgeleiden voor de periode 1993-2000 volgens het basisscenario. Daarna zal in hoofdstuk 4 de verwachte arbeidsmarktinstroom van schoolverlaters voor de onderscheiden technische opleidingen worden belicht. Vervolgens zal in hoofdstuk 5 een confrontatie van vraag en aanbod worden gemaakt, zodat een beeld wordt verkregen van de toekomstige arbeidsmarktsituatie van technisch opgeleiden. In hoofdstuk 6 zullen enkele alternatieve scenario's worden gepresenteerd. Hoofdstuk 7 geeft een overzicht van de belangrijkste conclusies en geeft bovendien een beeld van de beleidsimplicaties van de onderzoeksresultaten. Tot slot wordt gewezen op de bijlage achterin dit rapport. Daarin is voor elk van de onderscheiden opleidingen een 'opleidingsfiche' samengesteld, waarbij de belangrijkste elementen van de huidige en de te verwachten arbeidsmarktpositie worden belicht. 


\section{Actuele arbeidsmarktpositie van technisch opgeleiden}

\subsection{Inleiding}

In dit hoofdstuk wordt de actuele arbeidsmarktpositie van technisch opgeleiden in een breed kader bezien. Niet alleen voor de gehele technische beroepsbevolking, maar eveneens voor de schoolverlaters en recent afgestudeerden met een technische opleidingsachtergrond wordt ingegaan op een aantal karakteristieke kenmerken van hun arbeidsmarktpositie. Daarmee wordt een beter beeld verkregen van 'de directe aansluiting tussen het technisch onderwijs en de arbeidsmarkt. Tevens wordt ingegaan op de meer structurele positie van technisch opgeleiden op de arbeidsmarkt, zoals die bijvoorbeeld naar voren komt in de conjunctuurgevoeligheid van de werkgelegenheid en het 'bereik' dat men op de arbeidsmarkt heeft. Door bovendien op een aantal aspecten de verschillen in arbeidsmarktpositie tussen de beroepsbevolking als geheel en de schoolverlaters in het bijzonder in kaart te brengen, wordt een eerste beeld van te verwachten trends verkregen. Daarnaast geeft dit een eerste inzicht in de mogelijke loopbaanpatronen voor technisch opgeleiden.

Paragraaf 2.2 zal een beeld geven van de actuele arbeidsmarktpositie van de technisch opgeleide beroepsbevolking naar opleidingsniveau en -richting. In deze paragraaf zal tevens de risicopositie van de technisch opgeleide beroepsbevolking worden belicht. In paragraaf 2.3 wordt vervolgens ingegaan op gegevens over schoolverlaters en recent afgestudeerden met een technische opleidingsachtergrond. Ten slotte worden in paragraaf 2.4 de actuele arbeidsmarktsituatie van de technisch opgeleide beroepsbevolking en de schoolverlaters en recent afgestudeerden met elkaar vergeleken.

\subsection{Beroepsbevolking}

\section{Aantal werkenden}

In Nederland waren in 1993 in totaal ruim 5,9 miljoen mensen voor tenminste 12 uur per week werkzaam. Dit is ongeveer 40.000 meer dan in 1992. Tabel 2.1 geeft het aantal werkenden met een technische opleidingsachtergrond, waarbij een verbijzondering is gemaakt naar opleidingsniveau en -richting ${ }^{1}$. Daarbij is uitgegaan van de gemiddelde werkgelegenheid voor de jaren 1992-1993. Tabel B.1 van bijlage $B$ geeft daarnaast de belangrijkste bedrijfssectoren voor de technisch opgeleiden, terwijl in tabel B.2 een overzicht wordt gegeven van de belangrijkste ROA-beroepsklassen waarin personen met een technische opleiding werkzaam zijn.

Van de totale werkzame bevolking hebben ruim 1,4 miljoen personen een technische opleiding gevolgd. Daarvan heeft bijna de helft een opleidingsachtergrond op MBO-niveau ${ }^{2}$. Vooral sinds het begin van de jaren ' 80 is er sprake geweest van een enorme toename van het aantal arbeidskrachten met een opleiding op MBO-niveau. Deze periode wordt daarom ook wel getypeerd als het decennium van de MBO-isering van de vakarbeid (zie De Grip en Dekker, 1993). Dit heeft er toe geleid dat er momenteel ruim 700.000 arbeidskrachten met een MBO-opleiding in de technische richting in Nederland werkzaam zijn. Daarbinnen zijn de richtingen bouwkunde en elektrotechniek duidelijk het belangrijkste. Respectievelijk ongeveer 154.000 en 146.000 arbeidskrachten hebben een dergelijke opleiding gevolgd. Ook de

1. In bijlage A wordt een overzicht gegeven van de codering van deze opleidingen volgens de Standaard Onderwijsindeling (SOI).

2. Ook het merendeel van het leerlingwezen wordt tot dit opleidingsniveau gerekend. 
richting werktuigbouwkunde is met circa 88.000 werkenden redelijk groot. De werkgelegenheid voor de richtingen motorvoertuigentechniek en metaalkunde ligt momenteel net iets boven de 60.000 personen. Het aantal werkenden dat een MBO-opleiding technisch laboratorium, weg- en waterbouwkunde, procestechniek of fijnmechanische techniek heeft gevolgd, is relatief klein.

Tabel 2.1

Aantal en percentage werkende technisch opgeleiden naar opleidingsniveau en -richting, gemiddelde 1992-1993

\begin{tabular}{|c|c|c|}
\hline Opleidingsniveau en -richting & Aantal werkenden & $\%$ \\
\hline \multicolumn{3}{|l|}{ Wetenschappelijk onderwijs } \\
\hline Wiskunde en natuurwetenschappen & 38.000 & 2,6 \\
\hline $\begin{array}{l}\text { Technisch } \\
\text { bouwkunde/civiele techniek } \\
\text { werktuigbouwkunde } \\
\text { elektrotechniek/informatica }\end{array}$ & $\begin{array}{r}57.000 \\
19.000 \\
9.000 \\
11.000\end{array}$ & $\begin{array}{l}3,9 \\
1,3 \\
0,6 \\
0,8\end{array}$ \\
\hline \multicolumn{3}{|l|}{ Hoger beroepsonderwijs } \\
\hline Technisch laboratorium & 27.000 & 1,9 \\
\hline $\begin{array}{l}\text { Technisch } \\
\text { bouwkunde/weg- en waterbouwkunde } \\
\text { werktuigbouwkunde } \\
\text { elektrotechniek/informatica }\end{array}$ & $\begin{array}{r}121.000 \\
33.000 \\
30.000 \\
39.000\end{array}$ & $\begin{array}{l}8,4 \\
2,3 \\
2,1 \\
2,7\end{array}$ \\
\hline \multicolumn{3}{|l|}{ Middelbaar beroepsonderwijs } \\
\hline Technisch laboratorium & 12.000 & 0,8 \\
\hline $\begin{array}{l}\text { Technisch } \\
\text { bouwkunde } \\
\text { weg-en waterbouwkunde } \\
\text { metaalkunde } \\
\text { fijnmechanische techniek } \\
\text { werktuigbouwkunde } \\
\text { motorvoertuigentechniek } \\
\text { elektrotechniek } \\
\text { procestechniek }\end{array}$ & $\begin{array}{r}696.000 \\
154.000 \\
21.000 \\
62.000 \\
14.000 \\
88.000 \\
63.000 \\
146.000 \\
18.000\end{array}$ & $\begin{array}{r}48,1 \\
10,6 \\
1,5 \\
4,3 \\
1,0 \\
6,1 \\
4,4 \\
10,1 \\
1,2\end{array}$ \\
\hline \multicolumn{3}{|l|}{ Voorbereidend beroepsonderwijs } \\
\hline $\begin{array}{l}\text { Technisch } \\
\text { bouwtechniek } \\
\text { installatietechniek } \\
\text { metaalkunde } \\
\text { motorvoertuigentechniek } \\
\text { elektrotechniek } \\
\text { grafische techniek } \\
\text { consumptieve techniek }\end{array}$ & $\begin{array}{r}496.000 \\
137.000 \\
11.000 \\
140.000 \\
46.000 \\
63.000 \\
9.000 \\
26.000\end{array}$ & $\begin{array}{r}34,3 \\
9,5 \\
0,8 \\
9,7 \\
3,2 \\
4,4 \\
0,6 \\
1,8\end{array}$ \\
\hline Totaal technische opleidingen & 1.447 .000 & 100 \\
\hline
\end{tabular}

\section{Bron: CBS/ROA}

Ongeveer 500.000 arbeidskrachten hebben een technische opleiding afgerond binnen het VBO. Ruim één derde van de technisch opgeleide beroepsbevolking heeft daarmee een opleidingsachtergrond op VBO-niveau. Dit betekent dat na het MBO, het VBO de grootste leverancier is van technisch opgeleiden op de arbeidsmarkt. Binnen het voorbereidend technisch onderwijs zijn de richtingen metaalkunde en bouwtechniek het belangrijkste. Het aantal werkenden met een opleiding in de metaalkunde is circa 140.000 , terwijl ongeveer 137.000 personen werkzaam zijn met bouwtechniek als opleidingsachtergrond. Daarnaast hebben ruim 60.000 arbeidskrachten een opleiding VBO elektrotechniek gevolgd. Ook de 
richting motorvoertuigentechniek is met bijna 50.000 werkenden vrij groot. Consumptieve techniek, installatietechniek en grafische techniek zijn de kleinere richtingen op VBO-niveau.

In totaal zijn er in Nederland momenteel bijna een kwart miljoen mensen werkzaam die een technische opleiding in het hoger onderwijs hebben genoten. Daarvan hebben er ongeveer 100.000 een wetenschappelijke opleiding gevolgd, terwijl er circa 150.000 zijn afgestudeerd aan een HBO-instelling. Van de wetenschappelijk opgeleide arbeidskrachten hebben er ongeveer 38.000 een studie in de wiskunde of natuurwetenschappen afgerond. Circa 60.000 werkenden hebben een academische opleiding in de technische richting gevolgd. De studie bouwkunde/civiele techniek is daarbinnen de belangrijkste opleidingsrichting. Het aantal werkenden met een studie werktuigbouwkunde of elektrotechniek/informatica is relatief klein. Binnen het hoger beroepsonderwijs in de technische richting is daarentegen de richting elektrotechniek/informatica met 39.000 werkenden de grootste. Bouwkunde/weg- en waterbouwkunde en werktuigbouwkunde zijn echter eveneens vrij grote richtingen met beide circa 30.000 werkenden.

\section{Geslacht}

Vervolgens is het interessant om na te gaan hoeveel mannen en hoeveel vrouwen tot de werkzame bevolking met een technische opleidingsachtergrond behoren. In tabel 2.2 wordt daarom de man/vrouwverhouding van werkende technisch opgeleiden, verbijzonderd naar opleidingsniveau en -richting gepresenteerd. In totaal zijn er circa 90.000 vrouwen werkzaam met een opleiding in de technische richting. Dit betekent dat slechts ongeveer $6 \%$ van alle werkzame technisch opgeleiden vrouw is. Daarvan hebben ongeveer 9.000 vrouwen een wetenschappelijke opleidingsachtergrond, circa 11.000 een opleiding op HBO-niveau, ruim 40.000 een MBO-opleiding en ten slotte bijna 25.000 een opleiding op VBO-niveau.

Conform het algehele beeld is het aandeel vrouwen bij het gros van de technische opleidingen erg klein. Daarbij spant het technisch onderwijs op HBO-niveau de kroon met slechts een werkgelegenheidsaandeel van vrouwen van $3 \%$. Een uitzondering op dit punt wordt gevormd door de opleiding technisch laboratorium op zowel HBO- als MBO-niveau. Beide opleidingen hebben ongeveer $30 \%$ vrouwelijke arbeidskrachten. Ook in de academische studierichtingen in de wiskunde en natuurwetenschappen zijn vrouwen met circa $16 \%$ relatief sterk vertegenwoordigd. In alle andere opleidingsrichtingen zijn minder dan 3.000 vrouwen werkzaam ${ }^{3}$.

\section{Leeftijd}

Nogal eens wordt beweerd dat het innovatiepotentieel van de beroepsbevolking voor een belangrijk deel afhangt van het aantal jongeren dat een technische opleiding heeft gevolgd. Zij zijn immers in hun opleiding in aanraking gekomen met de moderne technologische ontwikkelingen. Bij veel oudere arbeidskrachten is waarschijnlijk een belangrijk deel van de technische kennis inmiddels verouderd, zeker wanneer deze gedurende hun loopbaan niet regelmatig is opgefrist via additionele scholing.

Aan de andere kant geeft de leeftijdsopbouw ook een beeld van de populariteitsgolven van de verschillende opleidingen. Een relatief groot aantal jongeren duidt er op dat de desbetreffende opleiding de afgelopen periode erg populair is geweest. Wanneer de werkzame bevolking met een bepaalde

3. Deze grens geldt bij het CBS als minimum voor publikatie van tweejaarsgemiddelde gegevens op basis van de EBB. 
opleidingsachtergrond verhoudingsgewijs sterk vergrijst, wijst dit er op dat momenteel weinig jongeren voor een dergelijke opleiding kiezen. Dit betekent echter ook dat er de komende jaren sprake zal zijn van een relatief grote uitstroom van arbeidskrachten van de arbeidsmarkt. Daarmee geeft de leeftijdsopbouw van de werkenden een belangrijke indicatie van de te verwachten vervangingsvraag.

Tabel 2.2

Man/vrouw-verhouding van werkende technisch opgeleiden naar opleidingsniveau en -richting, gemiddelde 1992-1993

\begin{tabular}{|c|c|c|}
\hline Opleidingsniveau en -richting & $\begin{array}{c}\text { mannen } \\
\%\end{array}$ & $\begin{array}{c}\text { vrouwen } \\
\%\end{array}$ \\
\hline \multicolumn{3}{|l|}{ Wetenschappelijk onderwijs } \\
\hline Wiskunde en natuurwetenschappen & 84 & 16 \\
\hline $\begin{array}{l}\text { Technisch } \\
\text { bouwkunde/civiele techniek } \\
\text { werktuigbouwkunde } \\
\text { elektrotechniek/informatica }\end{array}$ & $\begin{array}{r}95 \\
95 \\
100 \\
100\end{array}$ & $\begin{array}{l}5 \\
- \\
- \\
-\end{array}$ \\
\hline \multicolumn{3}{|l|}{ Hoger beroepsonderwijs } \\
\hline Technisch laboratorium & 67 & 30 \\
\hline $\begin{array}{l}\text { Technisch } \\
\text { bouwkunde/weg- en waterbouwkunde } \\
\text { werktuigbouwkunde } \\
\text { elektrotechniek/informatica }\end{array}$ & $\begin{array}{r}97 \\
97 \\
100 \\
97\end{array}$ & $\begin{array}{l}3 \\
- \\
- \\
-\end{array}$ \\
\hline \multicolumn{3}{|l|}{ Middelbaar beroepsonderwijs } \\
\hline Technisch laboratorium & 67 & 33 \\
\hline $\begin{array}{l}\text { Technisch } \\
\text { bouwkunde } \\
\text { weg- en waterbouwkunde } \\
\text { metaalkunde } \\
\text { fijnmechanische techniek } \\
\text { werktuigbouwkunde } \\
\text { motorvoertuigentechniek } \\
\text { elektrotechniek } \\
\text { procestechniek }\end{array}$ & $\begin{array}{r}94 \\
99 \\
100 \\
100 \\
93 \\
99 \\
100 \\
99 \\
94\end{array}$ & $\begin{array}{l}6 \\
- \\
- \\
- \\
- \\
- \\
- \\
- \\
-\end{array}$ \\
\hline \multicolumn{3}{|l|}{ Voorbereidend beroepsonderwijs } \\
\hline $\begin{array}{l}\text { Technisch } \\
\text { bouwtechniek } \\
\text { installatietechniek } \\
\text { metaalkunde } \\
\text { motorvoertuigentechniek } \\
\text { elektrotechniek } \\
\text { grafische techniek } \\
\text { consumptieve techniek }\end{array}$ & $\begin{array}{r}95 \\
100 \\
100 \\
100 \\
98 \\
100 \\
89 \\
92\end{array}$ & $\begin{array}{l}5 \\
- \\
- \\
- \\
- \\
- \\
- \\
-\end{array}$ \\
\hline
\end{tabular}

Bron: CBS/ROA

Op WO-niveau is het aantal werkenden min of meer evenwichtig over de onderscheiden leeftijdsklassen verdeeld. Een uitzondering zijn de academisch opgeleide wis- en natuurkundigen waarvan slechts $13 \%$ van de werkenden jonger dan 30 jaar is en een groot deel $(40 \%)$ in de leeftijdsklasse 30 tot en met 39 jaar valt. Van de overige technisch opgeleiden op WO-niveau is ruim $20 \%$ jonger dan 30 jaar, ongeveer $30 \%$ tussen de 30 en 39 jaar en eveneens ongeveer $30 \%$ is tussen de 40 en 49 . Een opvallende uitzondering wordt daarbij gevormd door de opleiding bouwkunde/civiele techniek. Bij deze richting is maar liefst bijna $60 \%$ van de werkenden 40 jaar of ouder. 
Eén derde van de technisch opgeleiden op HBO-niveau heeft een leeftijd tussen de 30 en 39 jaar. Verder is ongeveer een kwart van de werkenden met een technische opleidingsachtergrond op HBOniveau jonger dan 30 jaar, terwijl een ongeveer even groot deel tot de 40'ers behoort. De verschillen tussen de technische opleidingsrichtingen op HBO-niveau zijn klein. Ook hier vormt opvallend genoeg de richting (weg- en water)bouwkunde een uitzondering. Het aandeel werkenden dat jonger is dan 30 jaar is voor deze richting met $12 \%$ relatief erg klein.

Tabel 2.3

Percentage werkende technisch opgeleiden per leeftijdsklasse naar opleidingsniveau en -richting, gemiddelde 1992-1993

\begin{tabular}{lcccc}
\hline Opleidingsniveau en -richting & $\begin{array}{c}\text { jonger dan } \\
30 \text { jaar } \\
\%\end{array}$ & $\begin{array}{c}30-39 \text { jaar } \\
\%\end{array}$ & $\begin{array}{c}40-49 \text { jaar } \\
\%\end{array}$ & $\begin{array}{c}50 \text { jaar } \\
\text { of ouder } \\
\%\end{array}$ \\
\hline
\end{tabular}

Wetenschappelijk onderwijs

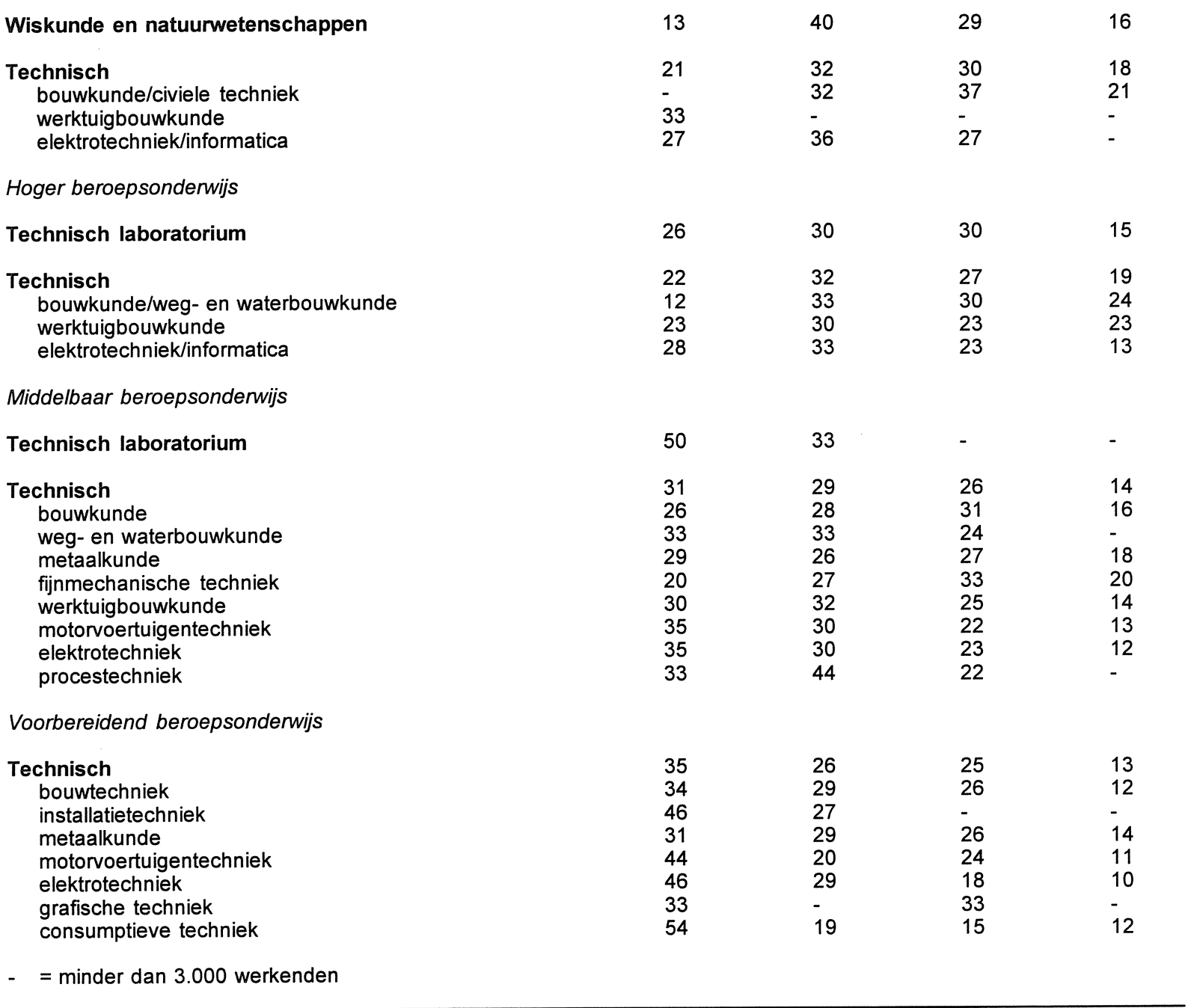

Bron: CBS/ROA

Het opleidingstype technisch laboratorium neemt bij de technische opleidingen op MBO-niveau een duidelijke uitzonderingspositie in. Maar liefst de helft van de werkenden met deze opleiding is jonger dan 30 jaar, terwijl één derde tussen de 30 en 39 jaar is. Mogelijk hangt dit samen met het feit dat in vergelijking met de andere technische opleidingen veel vrouwen, die vaak rond de geboorte van de 
kinderen terugtreden van het arbeidsproces, een dergelijke opleidingsachtergrond hebben. De verschillen in leeftijdsstructuur tussen de rest van de technische richtingen op MBO-niveau zijn, evenals op HBO-niveau, klein. Van de werkenden met een technische opleidingsachtergrond op MBO-niveau is gemiddeld ongeveer $30 \%$ jonger dan 30 jaar. Eveneens is ongeveer $30 \%$ van de arbeidskrachten tussen de 30 en 39 jaar, terwijl ruim een kwart tussen de 40 en 49 jaar oud is. Slechts ongeveer $14 \%$ van de werkenden met een middelbaar technische opleiding is 50 jaar of ouder. De MBO'ers fijnmechanische techniek zijn relatief wat ouder. Hiervan heeft circa één derde een leeftijd tussen de 40 en 49 jaar en is $20 \%$ ouder dan 50 jaar. Daarentegen zijn de werkenden met de opleidingsrichting procestechniek in het algemeen relatief jong. Bij deze opleiding is ruim drie kwart van de werkenden jonger dan 40 jaar.

Niet verwonderlijk is dat de werkenden met een VBO-opleiding in vergelijking met de andere opleidingsniveaus relatief jong zijn. De VBO'ers komen immers op jongere leeftijd op de arbeidsmarkt. Vooral de richtingen consumptieve techniek, elektrotechniek en installatietechniek hebben een jonge leeftijdsopbouw. Van de werkenden in deze richtingen is rond de $50 \%$ jonger dan 30 jaar. Bij de twee laatstgenoemde opleidingen is daarnaast nog eens bijna $30 \%$ tussen de 30 en 39 jaar. Hieruit kan worden afgeleid dat de bedrijfssectoren waarin veel technisch opgeleide VBO'ers werken in sterke mate afhankelijk zijn van schoolverlaters. Gezien de ontgroening van de beroepsbevolking brengt dit een groot risico met zich mee. Dit proces wordt daarbij bovendien nog eens versterkt door de toenemende doorstroom van leerlingen naar opleidingen op het niveau van MBO of leerlingwezen.

\section{Deeltijdarbeid}

Gegevens over het aantal werkenden in deeltijd hebben een tweeledige functie. Enerzijds vormen ze een indicatie van de mogelijkheden om in deeltijd te werken. Daar de mogelijkheid tot het werken in deeltijd in toenemende mate door de betrokkenen zelf als positief wordt beoordeeld, is dit een belangrijk gegeven. Anderzijds geven de gegevens echter ook een beeld van de mogelijke schaarsteverhoudingen op de arbeidsmarkt. Een groot percentage deeltijdwerkers kan er op wijzen dat er ruimte op de arbeidsmarkt is. De totale werkgelegenheid kan dan onder meer personen worden verdeeld, waardoor werkgevers meer mogelijkheden krijgen om flexibele arbeidscontracten af te sluiten. Dit betekent derhalve dat in dit geval een grote mate van deeltijdarbeid voor de werknemer als negatief moet worden beoordeeld.

Tabel 2.4 geeft het percentage werkende technisch opgeleiden dat een deeltijdbaan heeft van 32 uur of minder per week. Opvallend is dat voor de meeste technische opleidingen slechts een zeer gering deel in deeltijd werkzaam is. Op WO-niveau zijn de afgestudeerde wis- en natuurkundigen een uitzondering met relatief veel deeltijdarbeiders, namelijk $16 \%$. Op HBO-niveau geldt dit voor de opleidingsrichting technisch laboratorium, waarbij het percentage deeltijdwerkers $15 \%$ is. Ongetwijfeld hangt dit samen met het feit dat bij beide opleidingen ook relatief veel vrouwen werkzaam zijn. Een belangrijk deel van hen zal de functie in deeltijd vervullen. De overige technische studierichtingen op WO- en HBO-niveau kennen een zeer klein percentage deeltijdwerkers.

Ook bij de technische opleidingen op MBO-niveau is het percentage deeltijdwerkenden in het algemeen laag. Alleen bij de grote opleidingsrichtingen bouwkunde, motorvoertuigentechniek en elektrotechniek zijn er meer dan 3.000 werkenden die geen full-time aanstelling hebben. Op VBO-niveau ligt gemiddeld genomen het percentage deeltijdwerkers iets hoger dan bij de andere opleidingsniveaus. Een opmerkelijke uitschieter is de opleiding consumptieve techniek. Zo'n $15 \%$ van de arbeidskrachten met deze opleidingsachtergrond werkt minder dan 32 uur per week. Bij de opleidingen metaalkunde en elektro- 
techniek is het percentage deeltijdwerkers in vergelijking met de andere technische opleidingen op VBOniveau laag.

Het blijkt derhalve dat in het algemeen bij de opleidingen waar relatief veel vrouwen werkzaam zijn ook het percentage deeltijdwerkers het hoogst is. Het is op grond van deze cijfers niet duidelijk in welke mate bij de andere opleidingen al dan niet mogelijkheden tot het werken in deeltijd bestaan. Feit is wel dat momenteel, wellicht mede omdat er vooral mannen werkzaam zijn, weinig mensen met een dergelijke opleidingsachtergrond een functie in deeltijd invullen.

Tabel 2.4

Percentage deeltijdwerkers bij technisch opgeleiden naar opleidingsniveau en -richting, gemiddelde 1992-1993

Opleidingsniveau en -richting

Wetenschappelijk onderwijs

Wiskunde en natuurwetenschappen
Technisch
bouwkunde/civiele techniek
werktuigbouwkunde
elektrotechniek/informatica

Hoger beroepsonderwijs

Technisch laboratorium

Technisch

bouwkunde/weg- en waterbouwkunde

werktuigbouwkunde

elektrotechniek/informatica

Middelbaar beroepsonderwijs

Technisch laboratorium

Technisch

bouwkunde

weg- en waterbouwkunde

metaalkunde

fijnmechanische techniek

werktuigbouwkunde

motorvoertuigentechniek

elektrotechniek

procestechniek

Voorbereidend beroepsonderwijs

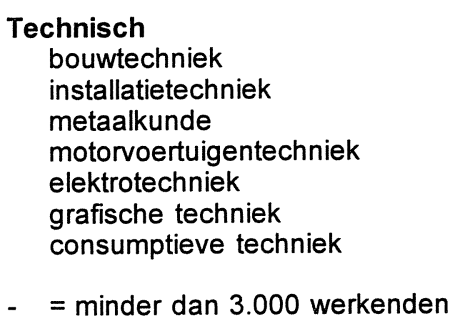

$=$ minder dan 3.000 werkenden

Bron: CBS/ROA

Werkloosheid

Een belangrijke indicator om de spanning op de arbeidsmarkt voor technisch opgeleiden weer te geven 
is vanzelfsprekend het werkloosheidspercentage. Al sinds enige jaren zijn er echter in Nederland geen betrouwbare sterk verbijzonderde werkloosheidsgegevens beschikbaar. Het is daarom helaas niet mogelijk om de werkloosheid onder de technisch opgeleide beroepsbevolking, verbijzonderd naar opleidingsrichting te presenteren. Wel zijn er sinds kort gegevens beschikbaar over de geregistreerde werkloosheid onder de technisch opgeleide beroepsbevolking naar opleidingsniveau en hoofdrichting. Deze zijn gepresenteerd in tabel 2.5. Daarbij wordt tevens per opleidingsniveau de werkloosheid onder technisch opgeleiden afgezet tegen de totale werkloosheid onder alle opleidingsrichtingen. Bovendien is in deze tabel een verbijzondering naar geslacht gemaakt.

Tabel 2.5

Werkloosheidspercentage naar opleidingsniveau hoofdrichting en geslacht, 1993

\begin{tabular}{|c|c|c|c|}
\hline Opleidingsniveau en hoofdrichting & $\underset{\%}{\operatorname{mannen}}$ & $\begin{array}{l}\text { vrouwen } \\
\%\end{array}$ & $\begin{array}{c}\text { totaal } \\
\%\end{array}$ \\
\hline Totaal Wo & 5,2 & 8,2 & 6,1 \\
\hline $\begin{array}{l}\text { WO Wiskunde en natuurwetenschappen } \\
\text { WO Technisch }\end{array}$ & - & - & - \\
\hline Totaal HBO & 3,3 & 7,6 & 5,1 \\
\hline $\begin{array}{l}\text { HBO Technisch laboratorium } \\
\text { HBO Technisch }\end{array}$ & - & - & $3, \overline{7}$ \\
\hline Totaal MBO & 3,4 & 8,2 & 5,2 \\
\hline $\begin{array}{l}\text { MBO Technisch laboratorium } \\
\text { MBO Technisch }\end{array}$ & 3,3 & 11,7 & $3, \overline{8}$ \\
\hline Totaal VBO & 5,7 & 14,1 & 8,4 \\
\hline VBO Technisch & 5,8 & 17,5 & 6,4 \\
\hline $\begin{array}{l}\text { Totaal alle opleidingen } \\
-\quad=\text { minder dan } 5.000 \text { werklozen }\end{array}$ & 5,7 & 10,5 & 7,5 \\
\hline
\end{tabular}

Bron: CBS, Enquête beroepsbevolking

In 1993 bedraagt de werkloosheid onder academisch opgeleiden gemiddeld 6,1\%. Daarbij zijn er relatief meer vrouwen dan mannen werkloos. Het werkloosheidspercentage onder vrouwen met een wetenschappelijke opleiding is $8,2 \%$, terwijl er slechts $5,2 \%$ mannen met een studie op WO-niveau werkloos zijn. Helaas kan hier niet expliciet worden ingegaan op de werkloosheid voor de beide onderscheiden opleidingstypen van het technisch onderwijs op WO-niveau. Wel is duidelijk dat het voor beide onderscheiden richtingen om minder dan 5.000 personen gaat.

De werkloosheid onder HBO'ers is in 1993 lager dan die onder universitair opgeleiden. Dit geldt zowel voor mannen als voor vrouwen. In totaal is $5,1 \%$ van de opgeleiden op HBO-niveau werkloos. Van de vrouwen met een $\mathrm{HBO}$-opleiding is $7,6 \%$ werkloos, terwijl onder de mannen met een $\mathrm{HBO}$-opleiding de werkloosheid slechts $3,3 \%$ bedraagt. In vergelijking met het totaalbeeld van het $\mathrm{HBO}$ is onder de technisch opgeleiden de werkloosheid, relatief laag. Voor de opleiding technisch laboratorium op HBOniveau kunnen helaas geen werkloosheidspercentages worden gegeven, omdat hier minder dan 5.000 personen werkloos zijn.

Ook binnen het MBO kunnen geen werkloosheidspercentages worden gepresenteerd voor de opleiding technisch laboratorium. Er zijn daarentegen wel gegevens beschikbaar over de werkloosheid onder de 
overig technisch opgeleide MBO'ers. Van de beroepsbevolking met deze opleidingsachtergrond is in $19933,8 \%$ werkloos, slechts een fractie hoger dan de werkloosheid onder technisch opgeleiden op HBO-niveau. Het werkloosheidspercentage onder technisch opgeleide mannen op MBO-niveau is 3,3\%. Van de vrouwen met een MBO-opleiding in de technische richting is echter opvallend genoeg maar liefst $11,7 \%$ werkloos. In vergelijking met het werkloosheidspercentage onder alle MBO'ers is de werkloosheid onder technisch opgeleiden relatief laag. Opmerkelijk is wel dat de werkloosheid onder vrouwen met een technische opleiding op MBO-niveau in vergelijking met alle vrouwelijke MBO'ers relatief erg hoog is.

De werkloosheid onder VBO'ers ligt in vergelijking met de andere opleidingsniveaus duidelijk op een hoger niveau. Gemiddeld gezien over de gehele beroepsbevolking met een VBO-opleidingsachtergrond bedraagt de werkloosheid $8,4 \%$. Onder de technisch opgeleide VBO'ers is de werkloosheid met $6,4 \%$ beduidend lager. Ook hier geldt dat er relatief gezien veel meer vrouwen dan mannen werkloos zijn. Het werkloosheidspercentage onder mannen met een opleiding op VBO-niveau bedraagt 5,7\%; bij vrouwen is dit $14,1 \%$. Bij de technische opleidingen is het verschil in werkloosheidspercentage tussen mannen en vrouwen nog veel extremer. Terwijl van de mannen met een opleiding VBO technisch nog geen $6 \%$ werkloos is, bedraagt het werkloosheidspercentage onder vrouwen met een dergelijke opleidingsachtergrond maar liefst meer dan $17 \%$. Overigens kan daarbij wellicht een deel van het verschil worden toegeschreven aan het feit dat vrouwen binnen het technisch onderwijs in andere richtingen vertegenwoordigd zijn dan mannen.

\section{Onderbenutting}

Wanneer er bij een bepaalde opleidingsrichting overschotten op de arbeidsmarkt dreigen te ontstaan, hoeven deze zich echter niet noodzakelijkerwijs te uiten in werkloosheid. Als er te weinig banen beschikbaar zijn op het niveau waarop men is opgeleid, dan kan het zo zijn dat arbeidskrachten banen accepteren die beneden hun opleidingsniveau liggen om zo in feite de dreiging van werkloosheid te omzeilen. Men spreekt dan van onderbenutting ${ }^{4}$.

In tabel 2.6 wordt een overzicht gegeven van het percentage werkende technisch opgeleiden dat onderbenut wordt, verbijzonderd naar opleidingsniveau en -richting. Daarbij wordt uitgegaan van de door Huijgen (1989) ontwikkelde indicator ${ }^{5}$. De onderbenutting is bij technisch opgeleiden op WO- en HBOniveau relatief het geringst. Bij ongeveer 10 tot $15 \%$ van de hoger technisch opgeleiden is er sprake van onderbenutting. Een opvallend hoge uitschieter wordt daarbij gevormd door de studierichting WO elektrotechniek/informatica. Ook bij de werktuigbouwkunde-opleiding op HBO-niveau is het percentage onderbenutting in vergelijking met de andere hogere opleidingen in de technische richting vrij hoog. Op WO-niveau kent deze studierichting daarentegen slechts een geringe mate van onderbenutting.

Bij de technisch opgeleiden op MBO-niveau is het percentage werkenden dat onderbenut wordt duidelijk hoger. Vooral bij de richtingen metaalkunde en procestechniek is er sprake van een grote mate van onderbenutting. Van degenen die een opleiding MBO elektrotechniek hebben gevolgd, worden er

4. Overigens hebben Wieling en Borghans (1995) in een eerste voorlopige analyse onlangs aangetoond dat discrepanties tussen vraag en aanbod op de arbeidsmarkt vooral leiden tot aanpassingsprocessen in de vorm van onderbenutting en beloning en niet zo zeer in werkloosheid.

5. Inmiddels is er enige kritiek op deze indicator, met name ook omdat de door Huijgen gehanteerde functieniveauindeling op belangrijke punten verouderd is. De resultaten moeten daarom met de nodige voorzichtigheid worden geïnterpreteerd. 
daarentegen relatief weinig onderbenut. Ook bij de laboratoriumopleiding op MBO-niveau is het percentage onderbenutting verhoudingsgewijs laag.

Op VBO-niveau is de onderbenutting van werkenden met een technische opleidingsachtergrond het grootst. Het gemiddelde percentage onderbenutting bij technici op VBO-niveau is $40 \%$. Binnen het VBO zijn de verschillen tussen de onderscheiden opleidingsrichtingen niet zo groot als bij de MBO-opleidingen. Bij de richtingen bouwtechniek, metaalkunde, motorvoertuigentechniek en consumptieve techniek wordt rond $40 \%$ van de werkenden onderbenut. Alleen onder de opgeleiden in de grafische techniek is het percentage arbeidskrachten dat in hun kwalificaties wordt onderbenut beduidend kleiner.

Tabel 2.6

Percentage werkende technisch opgeleiden dat wordt onderbenut naar opleidingsniveau en -richting, gemiddelde 1992-1993

Opleidingsniveau en -richting

Wetenschappelijk onderwijs

Wiskunde en natuurwetenschappen

Technisch

bouwkunde/civiele techniek

werktuigbouwkunde

elektrotechniek/informatica

\section{4}

12

Hoger beroepsonderwijs

Technisch laboratorium

Technisch

bouwkunde/weg- en waterbouwkunde

werktuigbouwkunde

elektrotechniek/informatica

Middelbaar beroepsonderwijs

Technisch laboratorium

Technisch

bouwkunde

weg- en waterbouwkunde

metaalkunde

fijnmechanische techniek

werktuigbouwkunde

motorvoertuigentechniek

elektrotechniek

procestechniek

Voorbereidend beroepsonderwijs

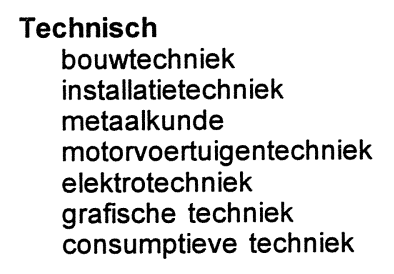

Bron: CBS/ROA

\section{Conjunctuurgevoeligheid}

Naast de indicatoren die meer de actuele arbeidsmarktsituatie voor technisch opgeleiden aangeven, is 
vanzelfsprekend ook de meer structurele kenmerken van de situatie op de arbeidsmarkt van belang. Een eerste belangrijke indicator hiervoor is de conjunctuurgevoeligheid van de werkgelegenheid. Deze indicator geeft de gevoeligheid van de werkgelegenheid voor een opleidingsrichting bij fluctuaties in de economische situatie. Het is met andere woorden een maat voor de werkzekerheid van de werkenden met een bepaalde opleidingsrichting.

Tabel 2.7 presenteert de conjunctuurgevoeligheid van de werkgelegenheid voor technisch opgeleiden, verbijzonderd naar opleidingsniveau en -richting. Daarbij is aan de relatief abstracte indicatorwaarde tevens een kwalitatieve typering verbonden (zie voor de intervalgrenzen Dekker, De Grip, Borghans, Matheeuwsen, Wieling en Willems, 1993). Het blijkt dat de conjunctuurgevoeligheid van de werkgelegenheid van nagenoeg alle technisch opgeleiden vrij groot is. De werkgelegenheid voor hoger technisch opgeleiden is echter minder van de conjuncturele ontwikkeling afhankelijk dan de werkgelegenheid voor lager opgeleide technici.

Tabel 2.7

Conjunctuurgevoeligheid van de werkgelegenheid voor technisch opgeleiden naar opleidingsniveau en -richting

\begin{tabular}{|c|c|c|}
\hline Opleidingsniveau en -richting & conjunctuurindicator & typering \\
\hline \multicolumn{3}{|l|}{ Wetenschappelijk onderwijs } \\
\hline Wiskunde en natuurwetenschappen & 1,34 & klein \\
\hline $\begin{array}{l}\text { Technisch } \\
\text { bouwkunde/civiele techniek } \\
\text { werktuigbouwkunde } \\
\text { elektrotechniek/informatica }\end{array}$ & $\begin{array}{l}1,68 \\
1,39 \\
1,88 \\
1,88\end{array}$ & $\begin{array}{l}\text { gemiddeld } \\
\text { klein } \\
\text { gemiddeld } \\
\text { gemiddeld }\end{array}$ \\
\hline \multicolumn{3}{|l|}{ Hoger beroepsonderwijs } \\
\hline Technisch laboratorium & 1,68 & gemiddeld \\
\hline $\begin{array}{l}\text { Technisch } \\
\text { bouwkunde/weg- en waterbouwkunde } \\
\text { werktuigbouwkunde } \\
\text { elektrotechniek/informatica }\end{array}$ & $\begin{array}{l}1,95 \\
1,74 \\
2,00 \\
2,15\end{array}$ & $\begin{array}{l}\text { gemiddeld } \\
\text { gemiddeld } \\
\text { gemiddeld } \\
\text { gemiddeld }\end{array}$ \\
\hline \multicolumn{3}{|l|}{ Middelbaar beroepsonderwijs } \\
\hline Technisch laboratorium & 1,59 & gemiddeld \\
\hline $\begin{array}{l}\text { Technisch } \\
\text { bouwkunde } \\
\text { weg- en waterbouwkunde } \\
\text { metaalkunde } \\
\text { fijnmechanische techniek } \\
\text { werktuigbouwkunde } \\
\text { motorvoertuigentechniek } \\
\text { elektrotechniek } \\
\text { procestechniek }\end{array}$ & $\begin{array}{l}2,17 \\
2,68 \\
2,08 \\
2,24 \\
1,99 \\
2,20 \\
1,51 \\
2,22 \\
2,13\end{array}$ & $\begin{array}{l}\text { groot } \\
\text { erg groot } \\
\text { gemiddeld } \\
\text { groot } \\
\text { gemiddeld } \\
\text { groot } \\
\text { gemiddeld } \\
\text { groot } \\
\text { gemiddeld }\end{array}$ \\
\hline \multicolumn{3}{|l|}{ Voorbereidend beroepsonderwijs } \\
\hline $\begin{array}{l}\text { Technisch } \\
\text { bouwtechniek } \\
\text { installatietechniek } \\
\text { metaalkunde } \\
\text { motorvoertuigentechniek } \\
\text { elektrotechniek } \\
\text { grafische techniek } \\
\text { consumptieve techniek }\end{array}$ & $\begin{array}{l}2,14 \\
2,47 \\
2,70 \\
2,13 \\
1,69 \\
2,12 \\
1,91 \\
1,56\end{array}$ & $\begin{array}{l}\text { gemiddeld } \\
\text { groot } \\
\text { erg groot } \\
\text { gemiddeld } \\
\text { gemiddeld } \\
\text { gemiddeld } \\
\text { gemiddeld } \\
\text { gemiddeld }\end{array}$ \\
\hline
\end{tabular}

Bron: ROA 
De academische opleidingen bouwkunde/civiele techniek en wiskunde en natuurwetenschappen zijn het minst conjunctuurgevoelig. Zowel op HBO- als op MBO-niveau is de werkgelegenheid voor laboranten in vergelijking met de andere opleidingsrichtingen iets minder conjunctuurafhankelijk. De opleiding MBO motorvoertuigentechniek is eveneens minder gevoelig voor fluctuaties in de werkgelegenheid. De werkgelegenheid voor arbeidskrachten met een opleiding bouwkunde op MBO-niveau fluctueert daarentegen sterk met de economische situatie. Ook op VBO-niveau is met name de opleidingsrichting bouwtechniek erg conjunctuurgevoelig. Ook degenen die een opleiding in de installatietechniek op VBOniveau hebben gevolgd, hebben te kampen met een relatief sterk fluctuerende werkgelegenheid. De opleiding consumptieve techniek is relatief minder afhankelijk van de conjunctuur.

\section{Uitwijkmogelijkheden}

Ten slotte worden in deze paragraaf de uitwijkmogelijkheden van de onderscheiden opleidingscategorieën naar andere bedrijfsklassen en naar andere beroepen op een aansluitend of hoger functieniveau besproken. Deze indicatoren geven inzicht in de flexibiliteit op de arbeidsmarkt. De uitwijkmogelijkheden worden bepaald met behulp van de Gini-Hirschman spreidingsindex, die aangeeft in hoeverre de werkenden in een bepaald beroep of bedrijfsklasse geconcentreerd, of juist over een groot aantal beroepen of bedrijfsklassen verspreid werkzaam zijn. De index heeft de waarde 0 als een bepaalde groep technisch opgeleiden in één beroep of bedrijfsklasse is geconcentreerd. In dit geval is een opleiding sterk afhankelijk van de arbeidsmarktsituatie in het desbetreffende beroep of de desbetreffende bedrijfsklasse. Het andere uiterste is dat de index de waarde één heeft. In dat geval is een bepaalde groep opgeleiden precies gelijk over alle onderscheiden beroepen of bedrijfsklassen verdeeld. Dit betekent dat degenen met deze opleidingsachtergrond vele mogelijkheden hebben om bij een in het eigen segment verslechterende arbeidsmarktsituatie uit te wijken naar andere beroepen of bedrijfsklassen (zie ook De Grip, Van der Velden en Wieling, 1993).

In tabel 2.8 wordt een overzicht gegeven van de uitwijkmogelijkheden die technisch opgeleiden hebben naar beroepen op een aansluitend of hoger functieniveau 6 . De tabel laat zien dat technisch opgeleiden op MBO- en VBO-niveau in het algemeen de meeste uitwijkmogelijkheden hebben. Bij de opleidingen op het WO-niveau zijn de uitwijkmogelijkheden naar andere beroepen iets kleiner.

Binnen het middelbaar technisch onderwijs zijn de uitwijkmogelijkheden duidelijk het kleinst voor de opleiding technisch laboratorium. De uitwijkmogelijkheden worden hier zelfs als erg klein getypeerd. Voor de MBO-opleidingen metaalkunde, fijnmechanische techniek, werktuigbouwkunde en elektrotechniek is er daarentegen sprake van relatief veel mogelijkheden om uit te wijken naar andere beroepen. Ook binnen het VBO is er een vrij grote variatie in het arbeidsmarktbereik van de verschillende onderscheiden richtingen. Bij de opleiding installatietechniek zijn de uitwijkmogelijkheden verhoudingsgewijs erg klein. Daarentegen kennen de opleidingen metaalkunde en elektrotechniek, evenals op MBO-niveau, een vrij grote spreiding over de beroepen.

Bij de onderscheiden studierichtingen op universitair en HBO-niveau valt op dat de uitwijkmogelijkheden voor de opleiding WO bouwkunde/civiele techniek relatief gering zijn. Degenen met een opleiding in de

6. Het is niet zinvol om de uitwijkmogelijkheden per opleidingsniveau weer te geven. Impliciet wordt dan namelijk verondersteld dat de binnen het niveau onderscheiden opleidingen onderling perfect substitueerbaar zijn (zie ook Willems, 1993). In de tabellen met betrekking tot uitwijkmogelijkheden wordt deze spreidingsindex dan ook niet gepresenteerd. 
wiskunde of natuurwetenschappen komen daarentegen in een vrij breed scala van beroepen terecht.

Tabel 2.8

Uitwijkmogelijkheden naar beroepen op een aansluitend of hoger functieniveau voor technisch opgeleiden naar opleidingsniveau en -richting 1993

\begin{tabular}{|c|c|c|}
\hline Opleidingsniveau en -richting & spreidingsindex & typering \\
\hline \multicolumn{3}{|l|}{ Wetenschappelijk onderwijs } \\
\hline Wiskunde en natuurwetenschappen & 0,91 & groot \\
\hline $\begin{array}{l}\text { Technisch } \\
\text { bouwkunde/civiele techniek } \\
\text { werktuigbouwkunde } \\
\text { elektrotechniek/informatica }\end{array}$ & $\begin{array}{l}0,80 \\
0,88 \\
0,82\end{array}$ & $\begin{array}{l}\text { klein } \\
\text { gemiddeld } \\
\text { gemiddeld }\end{array}$ \\
\hline \multicolumn{3}{|l|}{ Hoger beroepsonderwijs } \\
\hline Technisch laboratorium & 0,87 & gemiddeld \\
\hline $\begin{array}{l}\text { Technisch } \\
\text { bouwkunde/weg- en waterbouwkunde } \\
\text { werktuigbouwkunde } \\
\text { elektrotechniek/informatica }\end{array}$ & $\begin{array}{l}0,87 \\
0,95 \\
0,87\end{array}$ & $\begin{array}{l}\text { gemiddeld } \\
\text { groot } \\
\text { gemiddeld }\end{array}$ \\
\hline \multicolumn{3}{|l|}{ Middelbaar beroepsonderwijs } \\
\hline Technisch laboratorium & 0,62 & erg klein \\
\hline $\begin{array}{l}\text { Technisch } \\
\text { bouwkunde } \\
\text { weg- en waterbouwkunde } \\
\text { metaalkunde } \\
\text { fijnmechanische techniek } \\
\text { werktuigbouwkunde } \\
\text { motorvoertuigentechniek } \\
\text { elektrotechniek } \\
\text { procestechniek }\end{array}$ & $\begin{array}{l}0,89 \\
0,87 \\
0,92 \\
0,94 \\
0,95 \\
0,81 \\
0,94 \\
0,85\end{array}$ & $\begin{array}{l}\text { gemiddeld } \\
\text { gemiddeld } \\
\text { groot } \\
\text { groot } \\
\text { groot } \\
\text { gemiddeld } \\
\text { groot } \\
\text { gemiddeld }\end{array}$ \\
\hline \multicolumn{3}{|l|}{ Voorbereidend beroepsonderwijs } \\
\hline $\begin{array}{l}\text { Technisch } \\
\text { bouwtechniek } \\
\text { installatietechniek } \\
\text { metaalkunde } \\
\text { motorvoertuigentechniek } \\
\text { elektrotechniek } \\
\text { grafische techniek } \\
\text { consumptieve techniek }\end{array}$ & $\begin{array}{l}0,84 \\
0,58 \\
0,96 \\
0,85 \\
0,92 \\
0,89 \\
0,86\end{array}$ & $\begin{array}{l}\text { gemiddeld } \\
\text { erg klein } \\
\text { groot } \\
\text { gemiddeld } \\
\text { groot } \\
\text { gemiddeld } \\
\text { gemiddeld }\end{array}$ \\
\hline
\end{tabular}

Bron: ROA

Daarbij moet echter worden beseft dat tot dit opleidingstype een groot aantal vrij kleine studierichtingen wordt gerekend met elk hun eigen arbeidsmarktbereik. De hier gepresenteerde cijfers geven daardoor een enigszins vertekend beeld van de feitelijke uitwijkmogelijkheden op de arbeidsmarkt. Binnen het technisch onderwijs op HBO-niveau zijn de uitwijkmogelijkheden het grootst voor de richting werktuigbouwkunde. Ook op MBO- en WO-niveau behoort deze richting tot de opleidingen met het grootste arbeidsmarktbereik.

Tabel 2.9 geeft vervolgens voor de technische opleidingen een overzicht van de uitwijkmogelijkheden naar andere bedrijfsklassen. In deze tabel valt op dat de mogelijkheden om uit te wijken naar andere 
bedrijfsklassen voor de onderscheiden technische opleidingsrichtingen nogal verschillend zijn. Er blijkt sprake te zijn van een veel grotere variatie bij de uitwijkmogelijkheden naar andere bedrijfsklassen dan bij de uitwijkmogelijkheden naar andere beroepen.

Tabel 2.9

Uitwijkmogelijkheden naar andere bedrijfsklassen voor technisch opgeleiden naar opleidingsniveau en -richting 1993

\begin{tabular}{|c|c|c|}
\hline Opleidingsniveau en -richting & spreidingsindex & typering \\
\hline \multicolumn{3}{|l|}{ Wetenschappelijk onderwijs } \\
\hline Wiskunde en natuurwetenschappen & 0,82 & gemiddeld \\
\hline $\begin{array}{l}\text { Technisch } \\
\text { bouwkunde/civiele techniek } \\
\text { werktuigbouwkunde } \\
\text { elektrotechniek/informatica }\end{array}$ & $\begin{array}{l}0,68 \\
0,92 \\
0,88\end{array}$ & $\begin{array}{l}\text { klein } \\
\text { groot } \\
\text { gemiddeld }\end{array}$ \\
\hline \multicolumn{3}{|l|}{ Hoger beroepsonderwijs } \\
\hline Technisch laboratorium & 0,94 & groot \\
\hline $\begin{array}{l}\text { Technisch } \\
\text { bouwkunde/weg- en waterbouwkunde } \\
\text { werktuigbouwkunde } \\
\text { elektrotechniek/informatica }\end{array}$ & $\begin{array}{l}0,80 \\
0,93 \\
0,89\end{array}$ & $\begin{array}{l}\text { gemiddeld } \\
\text { groot } \\
\text { gemiddeld }\end{array}$ \\
\hline \multicolumn{3}{|l|}{ Middelbaar beroepsonderwijs } \\
\hline Technisch laboratorium & 0,93 & groot \\
\hline $\begin{array}{l}\text { Technisch } \\
\text { bouwkunde } \\
\text { weg- en waterbouwkunde } \\
\text { metaalkunde } \\
\text { fijnmechanische techniek } \\
\text { werktuigbouwkunde } \\
\text { motorvoertuigentechniek } \\
\text { elektrotechniek } \\
\text { procestechniek }\end{array}$ & $\begin{array}{l}0,78 \\
0,76 \\
0,92 \\
0,95 \\
0,96 \\
0,84 \\
0,95 \\
0,86\end{array}$ & $\begin{array}{l}\text { klein } \\
\text { klein } \\
\text { groot } \\
\text { groot } \\
\text { erg groot } \\
\text { gemiddeld } \\
\text { groot } \\
\text { gemiddeld }\end{array}$ \\
\hline \multicolumn{3}{|l|}{ Voorbereidend beroepsonderwijs } \\
\hline $\begin{array}{l}\text { Technisch } \\
\text { bouwtechniek } \\
\text { installatietechniek } \\
\text { metaalkunde } \\
\text { motorvoertuigentechniek } \\
\text { elektrotechniek } \\
\text { grafische techniek } \\
\text { consumptieve techniek }\end{array}$ & $\begin{array}{l}0,83 \\
0,81 \\
0,96 \\
0,95 \\
0,96 \\
0,77 \\
0,92\end{array}$ & $\begin{array}{l}\text { gemiddeld } \\
\text { gemiddeld } \\
\text { erg groot } \\
\text { groot } \\
\text { erg groot } \\
\text { klein } \\
\text { groot }\end{array}$ \\
\hline
\end{tabular}

Bron: ROA

Wanneer een vergelijking over de verschillende opleidingsniveaus wordt gemaakt, blijkt dat in het algemeen de technische richtingen op MBO- en VBO-niveau de meeste uitwijkmogelijkheden naar andere bedrijfsklassen hebben. De VBO-opleidingen met de meeste arbeidsmarktflexibiliteit over de bedrijfsklassen zijn metaalkunde en elektrotechniek. De opleiding grafische techniek heeft het meest beperkte arbeidsmarktbereik van de technische opleidingen op VBO-niveau. Binnen het middelbaar technisch onderwijs hebben de arbeidskrachten met een opleiding werktuigbouwkunde de meeste uitwijkmogelijkheden naar andere bedrijfsklassen. De MBO'ers weg- en waterbouwkunde zijn daarentegen het sterkst in een beperkt aantal sectoren geconcentreerd. Ook degenen die een opleiding bouwkunde op MBO-niveau hebben gevolgd, hebben minder mogelijkheden om uit te wijken naar 
andere bedrijfsklassen.

Opvallend is dat evenals op MBO-niveau, ook op HBO- en WO-niveau de arbeidskrachten met een bouwkunde-opleiding een relatief gering aantal uitwijkmogelijkheden hebben. Daarentegen zijn degenen die een opleiding werktuigbouwkunde op HBO- of WO-niveau hebben gevolgd in relatief veel bedrijfsklassen vertegenwoordigd. Ook bij het opleidingstype HBO technisch laboratorium zijn de uitwijkmogelijkheden naar andere bedrijfsklassen relatief groot.

Wanneer voor de onderscheiden opleidingen de uitwijkmogelijkheden naar andere beroepen en naar andere bedrijfsklassen met elkaar worden vergeleken, kunnen enkele belangrijke trends worden gesignaleerd. Binnen het wetenschappelijk onderwijs valt op dat de richting bouwkunde/civiele techniek een relatief beperkt arbeidsmarktbereik heeft. Zowel qua andere bedrijfsklassen als qua andere beroepen zijn de uitwijkmogelijkheden gering. Dit maakt dat de afgestudeerden in deze richting een groter risico lopen wanneer de arbeidsmarktperspectieven, bijvoorbeeld als gevolg van een algehele conjuncturele neergang, slechter worden. Degenen die een opleiding werktuigbouwkunde hebben gevolgd zijn duidelijk flexibeler op de arbeidsmarkt. Dit blijkt niet alleen op WO-niveau het geval te zijn, maar vooral ook op HBO-niveau.

Op MBO-niveau zijn er enkele opleidingen met een relatief groot arbeidsmarktbereik. Voor de richtingen metaalkunde, fijnmechanische techniek, werktuigbouwkunde en elektrotechniek zijn zowel de uitwijkmogelijkheden naar andere bedrijfsklassen als naar andere beroepen als groot getypeerd. Een opmerkelijk verschijnsel doet zich voor bij het opleidingstype MBO technisch laboratorium. Hierbij is er sprake van een sterke concentratie van de werkenden in een beperkt aantal beroepen, maar is er juist een vrij grote spreiding over de verschillende bedrijfsklassen.

Bij de opleidingen op VBO-niveau is vooral het beeld voor de opleidingen metaalkunde en elektrotechniek opvallend. Voor beide opleidingsrichtingen geldt dat de uitwijkmogelijkheden naar beroepen op een aansluitend of hoger functieniveau relatief groot zijn. De uitwijkmogelijkheden naar andere bedrijfsklassen worden voor deze opleidingen zelfs als erg groot getypeerd. Geconcludeerd kan derhalve worden dat personen met een dergelijke opleidingsachtergrond erg flexibel zijn op de arbeidsmarkt.

\subsection{Schoolverlaters en recent afgestudeerden}

Naast het in kaart brengen van de actuele arbeidsmarktpositie van de technisch opgeleide beroepsbevolking, is het tevens van belang om een beeld te verkrijgen van de marktpositie die schoolverlaters en recent afgestudeerden op de arbeidsmarkt innemen. De nieuwkomers op de arbeidsmarkt ondervinden immers als één van de eersten de gevolgen van veranderingen in deze marktpositie. De marktpositie van schoolverlaters en recent afgestudeerden kan daarmee worden beschouwd als een 'leading indicator' voor de marktpositie van de gehele beroepsbevolking. Bovendien wordt op deze manier beter in kaart gebracht hoe de directe aansluiting tussen het onderwijs en de arbeidsmarkt is.

De positie van nieuwkomers op de arbeidsmarkt kan in beeld worden gebracht op basis van de gegevens van de grootschalige schoolverlatersenquêtes Registratie Uitstroom en Bestemming van Schoolverlaters (RUBS) 1993 en HBO-monitor 1993 (zie respectievelijk Van Smoorenburg, Van der Velden, Van de Loo en Wieling, 1994 en Van de Loo en Van der Velden, 1994). Beide enquêtes hebben betrekking op de schoolverlaters van het schooljaar 1991-1992. De RUBS-enquête die wordt gehouden onder de schoolverlaters van het AVO, VBO en kort en lang MBO, heeft in het voorjaar van 1993 plaatsgevonden, een klein jaar na schoolverlaten. De enquête van de HBO-monitor is daarentegen 
eind 1993 / begin 1994 afgenomen, ongeveer anderhalf jaar na afstuderen. Bij de vergelijking van de resultaten tussen enerzijds het VBO en het MBO en anderzijds het HBO moet met dit verschil in enquête-moment rekening worden gehouden. Helaas zijn vergelijkbare gegevens voor wetenschappelijk opgeleiden momenteel niet beschikbaar.

\section{Werkloosheid}

Het eerste belangrijke kenmerk van de actuele arbeidsmarktsituatie van schoolverlaters en recent afgestudeerden is de werkloosheid onder deze nieuwkomers op de arbeidsmarkt. Een hoog werkloosheidspercentage kan immers duiden op een momenteel beperkte mogelijkheid voor de nieuwkomers om in te stromen op de arbeidsmarkt. In tabel 2.10 wordt een overzicht gegeven van de werkloosheid onder schoolverlaters en recent afgestudeerden, verbijzonderd naar opleidingsniveau en -richting ${ }^{7}$.

Tabel 2.10

Werkloosheid onder schoolverlaters en recent afgestudeerden naar opleidingsniveau en -richting 1993

Opleidingsniveau en -richting

Hoger beroepsonderwijs

Technisch laboratorium

Technisch

bouwkunde/weg- en waterbouwkunde

werktuigbouwkunde

elektrotechniek/informatica

19

10

22

Middelbaar beroepsonderwijs

$\begin{array}{ll}\text { Technisch laboratorium } & 7\end{array}$

Technisch

bouwkunde

weg- en waterbouwkunde

metaalkunde

fijnmechanische techniek

werktuigbouwkunde

motorvoertuigentechniek

elektrotechniek

procestechniek

26

Voorbereidend beroepsonderwijs

$\begin{array}{lr}\text { Technisch } & 5 \\ \text { bouwtechniek } & \\ \text { installatietechniek } & 3 \\ \text { metaalkunde } & 4 \\ \text { motorvoertuigentechniek } & \text { elektrotechniek } \\ \text { grafische techniek } & 11 \\ \text { consumptieve techniek } & 4 \\ \quad=\text { geen informatie i.v.m. te weinig waarnemingen }\end{array}$

Bron: RUBS/HBO-Monitor/ROA

Uit de tabel blijkt dat in vergelijking met de schoolverlaters op MBO- en VBO-niveau het werkloosheidspercentage onder HBO-afgestudeerden relatief hoog is. Aangezien ook in 1992 de

7. Van enkele opleidingen op MBO- en VBO-niveau kunnen in deze paragraaf geen gegevens worden gepresenteerd, omdat de RUBS-enquête hiervoor te weinig waarnemingen bevat. 
werkloosheid onder recent afgestudeerden van het HBO duidelijk hoger was (zie Van de Loo, Van der Velden en Wieling, 1993 en ook Willems, 1993), kan dit verschil niet worden teruggevoerd op het verschil in enquêtedatum. Van de recent afgestudeerden HBO'ers met een opleiding in de technische richting is gemiddeld $19 \%$ ongeveer anderhalf jaar na afstuderen werkloos. Een belangrijk deel daarvan heeft overigens in de tussentijd wel een baan gehad. De afgestudeerden in de richting elektrotechniek/informatica worden met de hoogste werkloosheid geconfronteerd: $26 \%$. Onder de afgestudeerden van de HBO-opleidingen (weg- en water)bouwkunde en technisch laboratorium is het werkloosheidspercentage daarentegen relatief laag.

Van de schoolverlaters met een technische opleiding op MBO-niveau is gemiddeld slechts $5 \%$ een klein jaar na afstuderen werkloos. Binnen het MBO is de werkloosheid voor de opleidingen technisch laboratorium en elektrotechniek relatief hoog. Van zowel de schoolverlaters weg- en waterbouwkunde als de schoolverlaters motorvoertuigentechniek op MBO-niveau is slechts $2 \%$ werkloos.

Bij de technische opleidingen op VBO-niveau is de werkloosheid onder schoolverlaters evenals bij het MBO gemiddeld $5 \%$. Een zeer opvallende uitschieter wordt daarbij echter gevormd door de opleiding motorvoertuigentechniek. Ongeveer een jaar na afstuderen is $11 \%$ van de schoolverlaters met deze opleiding werkloos. Onder de schoolverlaters van de opleiding bouwtechniek bedraagt de werkloosheid daarentegen slechts $3 \%$.

Opvallend is dat het werkloosheidspercentage onder afgestudeerden met een technische opleiding op HBO-niveau erg hoog is in vergelijking met de werkloosheid onder de technisch opgeleide beroepsbevolking op dit onderwijsniveau. Van de afgestudeerden met een technische HBO-opleiding is maar liefst $19 \%$ werkloos. De werkloosheid onder arbeidskrachten met een technische HBO-opleiding is daarentegen slechts $4 \%$. Blijkbaar brengt de economische recessie juist voor hoger opgeleiden intredemoeilijkheden op de arbeidsmarkt met zich mee.

Op MBO-niveau is de werkloosheid onder de technisch opgeleide beroepsbevolking en de technisch opgeleide schoolverlaters ongeveer van dezelfde orde van grootte. Van de schoolverlaters met een technische MBO-opleiding is in $19935 \%$ werkloos, een iets hoger percentage dan de $4 \%$ werkloosheid onder de arbeidskrachten met een technische MBO-opleiding. Ook op VBO-niveau is het werkloosheidspercentage onder de technisch opgeleide beroepsbevolking en de technisch opgeleide schoolverlaters ongeveer even groot.

Naast de werkloosheid is het belangrijk om inzicht te hebben in de periode die verstrijkt tussen het verlaten van de met goed gevolg afgesloten opleiding en het vinden van een baan. Daarmee wordt met andere woorden een beeld verkregen van de moeite die schoolverlaters moeten doen om aan de slag te komen. Tabel 2.11 geeft een beeld van de duur van de intredewerkloosheid, dit is de totale werkloosheidsduur in het eerste jaar na afstuderen, onder schoolverlaters en recent afgestudeerden van de technische opleidingen.

De tabel laat zien dat voor de technische opleidingen het overgrote deel van de schoolverlaters en recent afgestudeerden binnen 3 maanden een baan heeft gevonden. Binnen het HBO zijn het vooral de elektrotechnici/informatici die wat moeilijker een baan vinden. De schoolverlaters van het technisch onderwijs op MBO-niveau blijken zelfs nog wat minder problemen te hebben met de intrede op de arbeidsmarkt. Een uitzondering zijn de MBO'ers werktuigbouwkunde en elektrotechniek waar wel enige absorptieproblemen lijken op te treden. Het merendeel van hen heeft echter toch binnen 3 maanden een baan weten te vinden. 
Tabel 2.11

Duur van de intredewerkloosheid onder schoolverlaters en recent afgestudeerden naar opleidingsniveau en -richting 1993

\begin{tabular}{lcccc}
\hline Opleidingsniveau en -richting & niet werkloos & geweest \\
$\%$ & $\begin{array}{c}1-3 \\
\%\end{array}$ & $\begin{array}{c}4-6 \\
\text { maanden } \\
\%\end{array}$ & $\begin{array}{c}\text { meer dan } 6 \\
\text { maanden } \\
\%\end{array}$ \\
\hline
\end{tabular}

Hoger beroepsonderwijs

\begin{tabular}{|c|c|c|c|c|}
\hline Technisch laboratorium & 57 & 33 & 5 & 4 \\
\hline $\begin{array}{l}\text { Technisch } \\
\text { bouwkunde/weg- en waterbouwkunde } \\
\text { werktuigbouwkunde } \\
\text { elektrotechniek/informatica }\end{array}$ & $\begin{array}{l}51 \\
71 \\
53 \\
39\end{array}$ & $\begin{array}{l}34 \\
24 \\
33 \\
40\end{array}$ & $\begin{array}{r}9 \\
2 \\
8 \\
12\end{array}$ & $\begin{array}{l}7 \\
4 \\
6 \\
8\end{array}$ \\
\hline \multicolumn{5}{|l|}{ Middelbaar beroepsonderwijs } \\
\hline Technisch laboratorium & 58 & 30 & 7 & 6 \\
\hline $\begin{array}{l}\text { Technisch } \\
\text { bouwkunde } \\
\text { weg- en waterbouwkunde } \\
\text { metaalkunde } \\
\text { fijnmechanische techniek } \\
\text { werktuigbouwkunde } \\
\text { motorvoertuigentechniek } \\
\text { elektrotechniek } \\
\text { procestechniek }\end{array}$ & $\begin{array}{r}67 \\
80 \\
87 \\
. \\
55 \\
75 \\
58 \\
.\end{array}$ & $\begin{array}{r}24 \\
16 \\
13 \\
. \\
33 \\
20 \\
30 \\
.\end{array}$ & $\begin{array}{l}6 \\
4 \\
0 \\
. \\
. \\
6 \\
3 \\
7 \\
.\end{array}$ & $\begin{array}{l}4 \\
0 \\
0 \\
. \\
6 \\
6 \\
3 \\
4\end{array}$ \\
\hline \multicolumn{5}{|l|}{ Voorbereidend beroepsondenwijs } \\
\hline $\begin{array}{l}\text { Technisch } \\
\text { bouwtechniek } \\
\text { installatietechniek } \\
\text { metaalkunde } \\
\text { motorvoertuigentechniek } \\
\text { elektrotechniek } \\
\text { grafische techniek } \\
\text { consumptieve techniek }\end{array}$ & $\begin{array}{r}79 \\
88 \\
72 \\
72 \\
78 \\
83\end{array}$ & $\begin{array}{l}16 \\
11 \\
21 \\
18 \\
16 \\
11\end{array}$ & $\begin{array}{l}2 \\
1 \\
4 \\
4 \\
3 \\
2 \\
0\end{array}$ & $\begin{array}{l}4 \\
8 \\
4\end{array}$ \\
\hline
\end{tabular}

Bron: RUBS/HBO-Monitor/ROA

De technisch opgeleide VBO'ers hebben in het algemeen weinig problemen met de intrede op de arbeidsmarkt. Gemiddeld genomen is zelfs ongeveer $80 \%$ helemaal niet werkloos geweest na het verlaten van de opleiding. Vooral degenen met een opleiding bouwtechniek blijken weinig problemen te hebben bij het vinden van een baan. Schoolverlaters met een opleiding VBO motorvoertuigentechniek ondervinden daarentegen iets meer moeite bij de intrede op de arbeidsmarkt. Toch is ook van deze richting slechts $8 \%$ meer dan 3 maanden werkloos geweest. Wel is er bij deze richting klaarblijkelijk sprake van instabiele arbeidsrelaties, aangezien zo'n jaar na schoolverlaten een relatief groot deel van de schoolverlaters werkloos is.

\section{Onderbenutting}

Juist schoolverlaters en recent afgestudeerden zullen bij een verslechterende arbeidsmarkt een baan beneden hun niveau (moeten) accepteren. Na verloop van tijd kunnen zij dan, al dan niet via promoties op een bedrijfsinterne arbeidsmarkt, doorstromen naar beroepen die qua niveau beter aansluiten bij hun gevolgde opleiding (zie De Grip, Heijke en Willems, 1992). Het is daarom interessant om na te gaan in hoeverre de nieuwkomers op de arbeidsmarkt het afgelopen jaar zijn uitgeweken naar beroepen beneden hun niveau. 
Tabel 2.12 geeft een overzicht van het percentage werkende schoolverlaters en recent afgestudeerden dat wordt onderbenut. Daarbij wordt een andere onderbenuttingsmaatstaf gehanteerd dan in paragraaf 2.2. We spreken hier van onderbenutting wanneer de schoolverlaters aangeven dat de opleidingsvereisten voor de functie die zij uitoefenen lager zijn dan hun daadwerkelijke opleidingsniveau.

Tabel 2.12

Percentage werkende schoolverlaters en recent afgestudeerden dat wordt onderbenut naar opleidingsniveau en -richting 1993

Hoger beroepsonderwijs

Technisch laboratorium 16

$\begin{array}{ll}\text { Technisch } & 20\end{array}$

bouwkunde/weg- en waterbouwkunde 18

$\begin{array}{lr}\text { werktuigbouwkunde } & 24 \\ & 24\end{array}$

elektrotechniek/informatica $\quad 24$

Middelbaar beroepsonderwijs

$\begin{array}{ll}\text { Technisch laboratorium } & 10\end{array}$

Technisch 31

$\begin{array}{ll}\text { bouwkunde } & 15\end{array}$

$\begin{array}{ll}\text { weg- en waterbouwkunde } & 18\end{array}$

metaalkunde

fijnmechanische techniek $\quad 27$

werktuigbouwkunde $\quad 27$

motorvoertuigentechniek 25

elektrotechniek 33

procestechniek

Voorbereidend beroepsonderwijs

Technisch

bouwtechniek

installatietechniek

metaalkunde

motorvoertuigentechniek

elektrotechniek

grafische techniek

consumptieve techniek

= geen informatie i.v.m. te weinig waarnemingen

Bron: RUBS/HBO-Monitor/ROA

De tabel laat een geheel ander beeld zien dan naar voren kwam in tabel 2.6, waarin een overzicht is gegeven van de onderbenutting bij de gehele technische beroepsbevolking. Was de onderbenutting bij de gehele technische beroepsbevolking het hoogste bij de technische opleidingsrichtingen op VBOniveau, bij schoolverlaters en recent afgestudeerden is de onderbenutting bij technisch opgeleide VBO'ers juist het laagst. Opvallend is daarbij dat schoolverlaters met een opleiding metaalkunde relatief vaak in hun kwalificaties worden onderbenut. De onderbenutting onder schoolverlaters van de opleiding VBO consumptieve techniek is daarentegen relatief laag.

Op HBO-niveau worden de recent afgestudeerde werktuigbouwkundigen en elektrotechnici/informatici het meest onderbenut. Ongeveer een kwart van de afgestudeerden in deze richtingen heeft een baan beneden hun niveau geaccepteerd. Gezien de ook al verhoudingsgewijs hoge werkloosheid onder de afgestudeerden van deze beide studierichtingen mag worden geconcludeerd dat hun huidige markt- 
positie relatief ongunstig is.

Binnen het MBO bestaan er voor technische schoolverlaters redelijk grote verschillen in de mate waarin men wordt onderbenut. In het oog springend is dat een hoog percentage van de schoolverlaters MBO elektrotechniek wordt onderbenut. Eén op de drie schoolverlaters van deze opleiding oefent een functie uit die beneden hun niveau ligt. Voor de richtingen technisch laboratorium en bouwkunde op MBOniveau is de mate van onderbenutting daarentegen relatief gering.

Inkomen

Een ander belangrijk kenmerk van de arbeidsmarktpositie van schoolverlaters en recent afgestudeerden is vanzelfsprekend het verdiende inkomen. Tabel 2.13 presenteert het gemiddelde bruto uurloon van de werkende schoolverlaters en recent afgestudeerden, verbijzonderd naar opleidingsniveau en -richting. Binnen het technisch HBO bestaan slechts kleine verschillen in het bruto uurloon dat werkende recent afgestudeerden gemiddeld genomen verdienen. Het verschil is maximaal 70 cent. Deze uurlonen zijn ongeveer gelijk aan het gemiddelde van alle recent afgestudeerden van het HBO (zie Van de Loo en Van der Velden, 1994). De recent afgestudeerde HBO'ers (weg- en water)bouwkunde verdienen het meest. Hun gemiddelde bruto uurloon is $f 19,48$. Recent afgestudeerden van de HBO-opleiding werktuigbouwkunde verdienen relatief het minst van de technisch opgeleide HBO'ers: bruto gemiddeld $f 18,81$ per uur.

De verschillen tussen de gemiddelde bruto uurlonen van schoolverlaters zijn binnen het technisch MBO het grootst. De schoolverlaters MBO motorvoertuigentechniek verdienen met gemiddeld $f$ 12,41 per uur het minste. Het verschil in inkomen met de schoolverlaters van MBO werktuigbouwkunde is erg groot. Bruto per maand komt dit neer op een verschil van maar liefst ruim 400 gulden. De schoolverlaters MBO werktuigbouwkunde zijn vaak langer werkloos, maar als ze werk hebben is hun inkomen wel goed. In vergelijking met de schoolverlaters van de andere opleidingen van het MBO verdienen de schoolverlaters van het technisch onderwijs goed. Voor het gehele MBO ligt het gemiddeld uurinkomen rond de 12 gulden (zie Van Smoorenburg, Van der Velden, Van de Loo en Wieling, 1994).

Ook bij het VBO springt het technisch onderwijs er qua inkomen er in positieve zin uit. Terwijl de schoolverlaters van het VBO technisch gemiddeld meer dan $f 7,50$ per uur verdienen, ligt bij de andere hoofdrichtingen binnen het VBO het gemiddeld bruto uurinkomen onder de 7 gulden. Binnen het VBO technisch verdienen de schoolverlaters consumptieve techniek en bouwtechniek relatief het meeste. De schoolverlaters met een opleiding VBO motorvoertuigentechniek en elektrotechniek komen er qua gemiddeld inkomen relatief slecht vanaf. Zeker voor de schoolverlaters van de opleiding motorvoertuigentechniek kan, mede gelet op de verhoudingsgewijs hoge werkloosheid, worden gesproken van een vrij zwakke marktpositie. 
Tabel 2.13

Gemiddeld bruto uurloon werkende schoolverlaters en recent afgestudeerden naar opleidingsniveau en -richting 1993

\begin{tabular}{|c|c|}
\hline Opleidingsniveau en -richting & guldens \\
\hline \multicolumn{2}{|l|}{ Hoger beroepsondenwijs } \\
\hline Technisch laboratorium & 18,86 \\
\hline $\begin{array}{l}\text { Technisch } \\
\text { bouwkunde/weg- en waterbouwkunde } \\
\text { werktuigbouwkunde } \\
\text { elektrotechniek/informatica }\end{array}$ & $\begin{array}{l}19,43 \\
19,48 \\
18,81 \\
19,14\end{array}$ \\
\hline \multicolumn{2}{|l|}{ Middelbaar beroepsonderwijs } \\
\hline Technisch laboratorium & 14,56 \\
\hline $\begin{array}{l}\text { Technisch } \\
\text { bouwkunde } \\
\text { weg- en waterbouwkunde } \\
\text { metaalkunde } \\
\text { fijnmechanische techniek } \\
\text { werktuigbouwkunde } \\
\text { motorvoertuigentechniek } \\
\text { elektrotechniek } \\
\text { procestechniek }\end{array}$ & $\begin{array}{r}12,87 \\
13,38 \\
14,82 \\
. \\
15,00 \\
12,41 \\
13,16 \\
.\end{array}$ \\
\hline \multicolumn{2}{|l|}{ Voorbereidend beroepsonderwijs } \\
\hline $\begin{array}{l}\text { Technisch } \\
\text { bouwtechniek } \\
\text { installatietechniek } \\
\text { metaalkunde } \\
\text { motorvoertuigentechniek } \\
\text { elektrotechniek } \\
\text { grafische techniek } \\
\text { consumptieve techniek }\end{array}$ & $\begin{array}{l}7,52 \\
8,16 \\
7,71 \\
6,59 \\
6,71 \\
8,19\end{array}$ \\
\hline
\end{tabular}

Bron: RUBS/HBO-Monitor/ROA

\section{Deeltijdarbeid}

Tabel 2.14 laat zien dat de recent afgestudeerden op HBO-niveau slechts in beperkte mate in deeltijd werken. Daarbij is er weinig verschil tussen de diverse studierichtingen. Op MBO-niveau werken relatief veel meer technische schoolverlaters in deeltijdbanen. De verschillen tussen de technische opleidingsrichtingen op MBO-niveau zijn echter erg groot. Van de schoolverlaters van de opleiding MBO weg- en waterbouwkunde werkt vrijwel niemand in deeltijd. Ook bij de richting technisch laboratorium is de mate van deeltijdarbeid relatief gering. Daarentegen is bij de opleidingsrichting MBO motorvoertuigentechniek het percentage deeltijdwerkers relatief hoog.

Door de schoolverlaters van het VBO technisch wordt het meeste in deeltijd gewerkt. Gemiddeld genomen oefent $85 \%$ van de schoolverlaters van deze opleiding de functie in deeltijd uit. Vooral de schoolverlaters met een consumptieve opleiding hebben vaak een deeltijdbaan. De hoge percentages deeltijdwerkers onder de schoolverlaters van het technisch onderwijs op VBO-niveau hangen in belangrijke mate samen met de doorstroom naar het leerlingwezen, waarbij er automatisch sprake is van werken en leren. 
Tabel 2.14

Percentage deeltijdwerkers bij werkende schoolverlaters en recent afgestudeerden naar opleidingsniveau en -richting 1993

\begin{tabular}{|c|c|}
\hline Opleidingsniveau en -richting & $\%$ \\
\hline \multicolumn{2}{|l|}{ Hoger beroepsonderwijs } \\
\hline Technisch laboratorium & 6 \\
\hline $\begin{array}{l}\text { Technisch } \\
\text { bouwkunde/weg- en waterbouwkunde } \\
\text { werktuigbouwkunde } \\
\text { elektrotechniek/informatica }\end{array}$ & $\begin{array}{l}5 \\
5 \\
3 \\
5\end{array}$ \\
\hline \multicolumn{2}{|l|}{ Middelbaar beroepsonderwijs } \\
\hline Technisch laboratorium & 5 \\
\hline $\begin{array}{l}\text { Technisch } \\
\text { bouwkunde } \\
\text { weg- en waterbouwkunde } \\
\text { metaalkunde } \\
\text { fijnmechanische techniek } \\
\text { werktuigbouwkunde } \\
\text { motorvoertuigentechniek } \\
\text { elektrotechniek } \\
\text { procestechniek }\end{array}$ & $\begin{array}{r}27 \\
19 \\
1 \\
. \\
19 \\
48 \\
26\end{array}$ \\
\hline \multicolumn{2}{|l|}{ Voorbereidend beroepsonderwijs } \\
\hline $\begin{array}{l}\text { Technisch } \\
\text { bouwtechniek } \\
\text { installatietechniek } \\
\text { metaalkunde } \\
\text { motorvoertuigentechniek } \\
\text { elektrotechniek } \\
\text { grafische techniek } \\
\text { consumptieve techniek }\end{array}$ & $\begin{array}{l}85 \\
85 \\
75 \\
91 \\
85 \\
95\end{array}$ \\
\hline
\end{tabular}

Bron: RUBS/HBO-Monitor/ROA

Ook in paragraaf 2.2 is reeds gebleken dat juist op de lagere opleidingsniveaus vaker in deeltijd wordt gewerkt. Toch is er ten aanzien van de beroepsbevolking en de schoolverlaters een opvallend verschil bij de opleiding HBO technisch laboratorium. Van de recent afgestudeerden in deze richting werkt slechts $6 \%$ in deeltijd, terwijl voor de gehele beroepsbevolking het aandeel van deeltijdwerkers bij deze opleiding $15 \%$ bedraagt. Waarschijnlijk hangt dit samen met het relatief grote aantal vrouwen dat een dergelijke opleiding heeft gevolgd. $\mathrm{Na}$ een aantal jaren in hun carrière stappen zij nogal eens, bijvoorbeeld in verband met de geboorte en opvoeding van kinderen, van een full-time functie over naar een part-time baan.

\section{Conjunctuurgevoeligheid}

De conjunctuurgevoeligheid van de werkgelegenheid is de eerste indicator die inzicht verschaft in de risicopositie van schoolverlaters en recent afgestudeerden op de arbeidsmarkt. Deze indicator geeft, zoals al eerder is vermeld, aan in hoeverre de werkgelegenheid fluctueert met de economische situatie. In tabel 2.15 wordt een overzicht gegeven van de conjunctuurgevoeligheid van de werkgelegenheid voor schoolverlaters en recent afgestudeerden van het technisch onderwijs, verbijzonderd naar opleidingsniveau en -richting. 
Tabel 2.15

Conjunctuurgevoeligheid van de werkgelegenheid voor schoolverlaters en recent afgestudeerden naar opleidingsniveau en -richting

\begin{tabular}{|c|c|c|}
\hline Opleidingsniveau en -richting & conjunctuurindicator & typering \\
\hline \multicolumn{3}{|l|}{ Hoger beroepsonderwijs } \\
\hline Technisch laboratorium & 1,68 & gemiddeld \\
\hline $\begin{array}{l}\text { Technisch } \\
\text { bouwkunde/weg- en waterbouwkunde } \\
\text { werktuigbouwkunde } \\
\text { elektrotechniek/informatica }\end{array}$ & $\begin{array}{l}1,88 \\
1,95 \\
2,13 \\
1,94\end{array}$ & $\begin{array}{l}\text { gemiddeld } \\
\text { gemiddeld } \\
\text { gemiddeld } \\
\text { gemiddeld }\end{array}$ \\
\hline \multicolumn{3}{|l|}{ Middelbaar beroepsonderwijs } \\
\hline Technisch laboratorium & 1,80 & gemiddeld \\
\hline $\begin{array}{l}\text { Technisch } \\
\text { bouwkunde } \\
\text { weg- en waterbouwkunde } \\
\text { metaalkunde } \\
\text { fijnmechanische techniek } \\
\text { werktuigbouwkunde } \\
\text { motorvoertuigentechniek } \\
\text { elektrotechniek } \\
\text { procestechniek }\end{array}$ & $\begin{array}{l}2,14 \\
2,69 \\
2,36\end{array}$ & $\begin{array}{l}\text { gemiddeld } \\
\text { erg groot } \\
\text { groot } \\
. \\
\text { groot } \\
\text { gemiddeld } \\
\text { groot }\end{array}$ \\
\hline \multicolumn{3}{|l|}{ Voorbereidend beroepsonderwijs } \\
\hline $\begin{array}{l}\text { Technisch } \\
\text { bouwtechniek } \\
\text { installatietechniek } \\
\text { metaalkunde } \\
\text { motorvoertuigentechniek } \\
\text { elektrotechniek } \\
\text { grafische techniek } \\
\text { consumptieve techniek }\end{array}$ & $\begin{array}{r}2,30 \\
2,97 \\
2,29 \\
1,70 \\
2,72 \\
1,31\end{array}$ & $\begin{array}{l}\text { groot } \\
\text { erg groot } \\
\text { groot } \\
\text { gemiddeld } \\
\text { erg groot } \\
\text { klein }\end{array}$ \\
\hline
\end{tabular}

Bron: RUBS/HBO-Monitor/ROA

Opvallend is dat de werkgelegenheid voor technisch opgeleide schoolverlaters en recent afgestudeerden iets conjunctuurgevoeliger is dan de werkgelegenheid voor de technische beroepsbevolking met dezelfde opleidingsachtergrond. Waarschijnlijk hangt dit samen met het feit dat de technisch opgeleide nieuwkomers op de arbeidsmarkt vaker terecht komen in een beperkt aantal conjunctuurgevoelige bedrijfsklassen, waarin ze een functie uitoefenen die relatief dicht bij hun opleiding staat. Naarmate men langer werkzaam is, is er bij technici nogal eens sprake van een verschuiving naar andersoortige functies, waardoor zij ook vaker in andere, minder van de conjunctuur afhankelijke, sectoren terechtkomen.

Binnen het HBO is de conjunctuurgevoeligheid van de werkgelegenheid voor afgestudeerden technisch laboratorium gering in vergelijking met de andere onderscheiden technische opleidingsrichtingen op HBO-niveau. Dit beeld is in overeenstemming met de situatie zoals die voor de gehele beroepsbevolking is geconstateerd. Bij de opleidingen op MBO-niveau valt op dat de richting technisch laboratorium eveneens vrij ongevoelig is voor fluctuaties in de werkgelegenheid. Daarnaast komen de schoolverlaters van de opleiding MBO motorvoertuigentechniek vaker in iets minder conjunctuurgevoelige sectoren terecht. Daarentegen is de werkgelegenheid voor schoolverlaters met een bouwkunde-opleiding op MBO-niveau erg gevoelig voor conjuncturele schommelingen in de werkgelegenheid. 
De tabel laat verder zien dat op VBO-niveau de werkgelegenheid van schoolverlaters van de opleiding consumptieve techniek in vergelijking met de andere technische VBO-opleidingen niet erg conjunctuurgevoelig is. De bouwsector is relatief erg conjunctuurgevoelig. De schoolverlaters van de opleidingen bouwtechniek en in iets mindere mate elektrotechniek, die sterk van deze sector afhankelijk zijn, nemen dientengevolge een meer risicovolle positie op de arbeidsmarkt in.

\section{Uitwijkmogelijkheden}

De uitwijkmogelijkheden van schoolverlaters en recent afgestudeerden naar andere beroepen op een aansluitend of hoger functieniveau vormen, zoals reeds eerder is aangegeven, een goede indicatie van hun flexibiliteit op de arbeidsmarkt. Tabel 2.16 presenteert per opleidingsniveau en -richting de uitwijkmogelijkheden. Deze zijn wederom bepaald met behulp van de Gini-Hirschman spreidingsindex.

Tabel 2.16

Uitwijkmogelijkheden naar beroepen op een aansluitend of hoger functieniveau voor schoolverlaters en recent afgestudeerden naar opleidingsniveau en -richting 1993

\begin{tabular}{|c|c|c|}
\hline Opleidingsniveau en -richting & spreidingsindex & typering \\
\hline \multicolumn{3}{|l|}{ Hoger beroepsonderwijs } \\
\hline Technisch laboratorium & 0,71 & klein \\
\hline $\begin{array}{l}\text { Technisch } \\
\text { bouwkunde/weg- en waterbouwkunde } \\
\text { werktuigbouwkunde } \\
\text { elektrotechniek/informatica }\end{array}$ & $\begin{array}{l}0,80 \\
0,88 \\
0,80\end{array}$ & $\begin{array}{l}\text { klein } \\
\text { gemiddeld } \\
\text { klein }\end{array}$ \\
\hline \multicolumn{3}{|l|}{ Middelbaar beroepsonderwijs } \\
\hline Technisch laboratorium & 0,45 & erg klein \\
\hline $\begin{array}{l}\text { Technisch } \\
\text { bouwkunde } \\
\text { weg- en waterbouwkunde } \\
\text { metaalkunde } \\
\text { fijnmechanische techniek } \\
\text { werktuigbouwkunde } \\
\text { motorvoertuigentechniek } \\
\text { elektrotechniek } \\
\text { procestechniek }\end{array}$ & $\begin{array}{l}0,87 \\
0,63 \\
0,84\end{array}$ & $\begin{array}{l}\text { klein } \\
\text { klein } \\
\text { gemiddeld } \\
\text { erg klein } \\
\text { gemiddeld } \\
\end{array}$ \\
\hline Voorbereidend beroepsonderwijs & & \\
\hline $\begin{array}{l}\text { Technisch } \\
\text { bouwtechniek } \\
\text { installatietechniek } \\
\text { metaalkunde } \\
\text { motorvoertuigentechniek } \\
\text { elektrotechniek } \\
\text { grafische techniek } \\
\text { consumptieve techniek }\end{array}$ & $\begin{array}{l}0,72 \\
0,92 \\
0,69 \\
0,69 \\
0,57\end{array}$ & $\begin{array}{l}\text { klein } \\
\text { groot } \\
\text { erg klein } \\
\text { erg klein } \\
\text { erg klein }\end{array}$ \\
\hline
\end{tabular}

Bron: RUBS/HBO-Monitor/ROA

Opvallend is dat voor de schoolverlaters van een groot aantal opleidingen de uitwijkmogelijkheden naar beroepen op een aansluitend of hoger functieniveau als klein of zelfs erg klein worden getypeerd. Hieruit zou eveneens kunnen worden afgeleid dat men in het begin van de loopbaan vaak in een beroep terecht komt dat relatief dicht bij de opleiding staat. Na verloop van enkele jaren waaieren de technisch opgeleiden nogal eens uit naar andere beroepen. 
Binnen het HBO is de beroepenspreiding van de afgestudeerden van de verschillende opleidingsrichtingen vrijwel aan elkaar gelijk. Alleen bij de opleiding werktuigbouwkunde zijn de uitwijkmogelijkheden iets groter. Op MBO-niveau worden de uitwijkmogelijkheden naar andere beroepen voor het opleidingstype technisch laboratorium als erg klein getypeerd. Hetzelfde is het geval voor de opleiding MBO motorvoertuigentechniek. Een positieve uitschieter wordt op dit niveau gevormd door de richtingen werktuigbouwkunde en elektrotechniek, waarvoor de uitwijkmogelijkheden als gemiddeld worden getypeerd. Bij de opleidingen op VBO-niveau valt vooral de richting metaalkunde op. In tegenstelling tot het algehele beeld voor de technische opleidingen zijn de uitwijkmogelijkheden naar andere beroepen voor de schoolverlaters van deze opleiding relatief groot. Daarentegen zijn de schoolverlaters van de opleidingen VBO motorvoertuigentechniek, elektrotechniek en consumptieve techniek sterk op slechts enkele beroepssegmenten gericht.

Tabel 2.17

Uitwijkmogelijkheden naar andere bedrijfsklassen voor schoolverlaters en recent afgestudeerden naar opleidingsniveau en -richting 1993

\begin{tabular}{|c|c|c|}
\hline Opleidingsniveau en -richting & spreidingsindex & typering \\
\hline \multicolumn{3}{|l|}{ Hoger beroepsonderwijs } \\
\hline Technisch laboratorium & 0,89 & gemiddeld \\
\hline $\begin{array}{l}\text { Technisch } \\
\text { bouwkunde/weg- en waterbouwkunde } \\
\text { werktuigbouwkunde } \\
\text { elektrotechniek/informatica }\end{array}$ & $\begin{array}{l}0,71 \\
0,94 \\
0,90\end{array}$ & $\begin{array}{l}\text { klein } \\
\text { groot } \\
\text { groot }\end{array}$ \\
\hline Middelbaar beroepsonderwijs & & \\
\hline Technisch laboratorium & 0,92 & groot \\
\hline $\begin{array}{l}\text { Technisch } \\
\text { bouwkunde } \\
\text { weg- en waterbouwkunde } \\
\text { metaalkunde } \\
\text { fijnmechanische techniek } \\
\text { werktuigbouwkunde } \\
\text { motorvoertuigentechniek } \\
\text { elektrotechniek } \\
\text { procestechniek }\end{array}$ & $\begin{array}{r}0,65 \\
0,71 \\
. \\
0,86 \\
0,71 \\
0,92 \\
.\end{array}$ & $\begin{array}{l}\text { klein } \\
\text { klein } \\
\text { gemiddeld } \\
\text { klein } \\
\text { groot } \\
\end{array}$ \\
\hline Voorbereidend beroepsondenwijs & & \\
\hline $\begin{array}{l}\text { Technisch } \\
\text { bouwtechniek } \\
\text { installatietechniek } \\
\text { metaalkunde } \\
\text { motorvoertuigentechniek } \\
\text { elektrotechniek } \\
\text { grafische techniek } \\
\text { consumptieve techniek }\end{array}$ & $\begin{array}{r}0,57 \\
0,91 \\
0,76 \\
0,74 \\
0,52\end{array}$ & $\begin{array}{l}\text { klein } \\
\text { groot } \\
\text { klein } \\
\text { klein } \\
\text { klein }\end{array}$ \\
\hline
\end{tabular}

Bron: RUBS/HBO-Monitor/ROA

Tabel 2.17 geeft vervolgens een overzicht van de uitwijkmogelijkheden voor schoolverlaters en recent afgestudeerden naar andere bedrijfsklassen. De mogelijkheden om uit te wijken naar andere bedrijfsklassen zijn, evenals bij de technisch opgeleide beroepsbevolking nogal verschillend voor de onderscheiden technische opleidingen. In vergelijking met de uitwijkmogelijkheden van de technisch opgeleide beroepsbevolking, hebben de schoolverlaters en recent afgestudeerden een beperkt arbeidsmarktbereik. 
Dit stemt overeen met de algehele lijn waarbij schoolverlaters en recent afgestudeerden in een beperkt aantal intredebanen de arbeidsmarkt betreden en pas uitwaaieren naar andere arbeidsmarktsegmenten als zij zich langer op de arbeidsmarkt bevinden.

Uit de tabel blijkt dat de afgestudeerden met een technische opleiding op HBO-niveau de meeste uitwijkmogelijkheden naar andere bedrijfsklassen hebben. Vooral de afgestudeerden met een opleiding HBO werktuigbouwkunde of elektrotechniek/informatica hebben een breed arbeidsmarktbereik. De afgestudeerde HBO'ers (weg- en water)bouwkunde hebben daarentegen slechts een beperkt aantal uitwijkmogelijkheden op de arbeidsmarkt.

Op MBO-niveau hebben de schoolverlaters van de meeste onderscheiden technische opleidingen een beperkt arbeidsmarktbereik. Uitzonderingen zijn daarbij de schoolverlaters van de opleidingen technisch laboratorium en elektrotechniek, die veel uitwijkmogelijkheden hebben naar andere bedrijfsklassen. De schoolverlaters van de opleiding bouwkunde hebben het meest beperkte arbeidsmarktbereik. Voor de opleiding MBO werktuigbouwkunde worden de uitwijkmogelijkheden als gemiddeld gekwalificeerd.

De uitwijkmogelijkheden op VBO-niveau zijn voor schoolverlaters met een technische opleidingsachtergrond zeer beperkt. Vooral de schoolverlaters met een opleiding bouwtechniek en consumptieve techniek hebben een erg beperkt arbeidsmarktbereik. Opvallend is dat de schoolverlaters met een VBOopleiding metaalkunde relatief veel uitwijkmogelijkheden hebben.

In het algemeen kan worden geconcludeerd dat de uitwijkmogelijkheden naar enerzijds andere beroepen en anderzijds andere bedrijfsklassen voor de onderscheiden opleidingen min of meer een zelfde beeld geven. Wel lijkt de afhankelijkheid van schoolverlaters van een beperkt aantal beroepen groter te zijn, terwijl men makkelijker over de verschillende bedrijfsklassen uitwaaiert. Evenals bij de gehele beroepsbevolking is dit het meest extreem het geval bij het opleidingstype MBO technisch laboratorium. Terwijl de uitwijkmogelijkheden naar andere beroepen voor schoolverlaters van deze opleiding erg klein zijn, bestaat er een grote flexibiliteit ten aanzien van de keuze voor de bedrijfsklasse.

Een andere manier om het arbeidsmarktbereik in beeld te brengen, is de 'uitval' van technisch opgeleiden bij hun intrede op de arbeidsmarkt, ofwel het percentage schoolverlaters en recent afgestudeerden dat niet in een technisch beroep werkzaam is ${ }^{8}$. Tabel 2.18 geeft hiervan een overzicht. In principe kunnen er twee redenen voor deze uitval worden aangevoerd. Enerzijds kan dit het gevolg zijn van een tekortschietend aantal baanopeningen voor nieuwkomers in de technische beroepen, waardoor schoolverlaters gedwongen zijn uit te wijken naar andere werkterreinen. Anderzijds kunnen de schoolverlaters ook zelf, afgezien van de arbeidsmarktsituatie, kiezen voor een beroep dat niet in de technische richting is.

Binnen het HBO blijken vooral de afgestudeerden van de studies technisch laboratorium en elektrotechniek/informatica in een niet-technisch beroep te werken. Respectievelijk $47 \%$ en $40 \%$ oefent een niet technisch beroep uit. Bij de richting elektrotechniek/informatica wordt dit beeld echter vertekend omdat de beroepsklasse 'systeemanalisten, -programmeurs en -beheerders' formeel tot de economischadministratieve beroepen wordt gerekend. Afgestudeerden in de richting bouwkunde/weg- en waterbouwkunde komen relatief vaak in een technisch beroep terecht.

8. Een overzicht van de onderscheiden technische beroepen is gegeven in bijlage $C$. Volgens de ROA-beroepenclassificatie zijn dit de beroepen, waarvan de code begint met een 3 . 
Ook op MBO-niveau blijkt dat de schoolverlaters van de bouwkunde-opleiding verhoudingsgewijs vaak een technisch beroep uitoefenen. Ook degenen die een MBO-opleiding werktuigbouwkunde hebben gevolgd, vinden dikwijls een baan een technisch beroep. Schoolverlaters van de opleidingen weg- en waterbouwkunde en motorvoertuigentechniek komen daarentegen relatief vaak in een niet-technisch beroep terecht.

Bij de opleidingen op VBO-niveau valt het hoge percentage schoolverlaters in de richting consumptieve techniek dat niet in een technisch beroep werkzaam is op. Gezien de aard van deze opleiding is dit echter niet zo vreemd. Bij de overige onderscheiden technische opleidingen op VBO-niveau varieert het percentage schoolverlaters dat niet in een technisch beroep werkzaam is van $19 \%$ voor de richting bouwtechniek tot $27 \%$ voor de richting elektrotechniek.

\section{Tabel 2.18}

Percentage schoolverlaters en recent afgestudeerden dat niet in een technisch beroep werkzaam is naar opleidingsniveau en -richting 1993

\section{Hoger beroepsondenwijs}

$\begin{array}{lr}\text { Technisch laboratorium } & 47\end{array}$

Technisch

bouwkunde/weg- en waterbouwkunde

elektrotechniek/informatica

Middelbaar beroepsonderwijs

Technisch laboratorium

Technisch

bouwkunde

13

weg- en waterbouwkunde

30

fijnmechanische techniek

werktuigbouwkunde

motorvoertuigentechniek

elektrotechniek

procestechniek

Voorbereidend beroepsonderwijs

Technisch

bouwtechniek

installatietechniek

metaalkunde

motorvoertuigentechniek

elektrotechniek

grafische techniek

consumptieve techniek

7
2
3
5
0

= geen informatie i.v.m. te weinig waarnemingen

Bron: RUBS/HBO-Monitor/ROA

Kwalitatieve aspecten

Tot slot van deze paragraaf wordt ingegaan op enkele kwalitatieve aspecten van de directe aansluiting onderwijs-arbeidsmarkt. In de schoolverlatersenquêtes konden de schoolverlaters en recent afgestudeerden aangeven of aan een bepaald aspect van de opleiding naar hun mening meer, evenveel of juist 
minder aandacht zou moeten worden besteed. Zijn de schoolverlaters of recent afgestudeerden van mening dat er meer aandacht aan een bepaald aspect zou moeten zijn besteed, dan duidt dit op een tekortkoming van de opleiding. Enerzijds kunnen schoolverlaters en afgestudeerden na het afronden van hun studie sowieso van mening zijn dat aan een aspect meer aandacht had moeten worden besteed. Anderzijds kan het er ook op wijzen dat werkende schoolverlaters en recent afgestudeerden op de arbeidsmarkt merken dat hun opleiding op bepaalde punten tekort is geschoten.

In tabel 2.19 wordt de mate van tevredenheid van (werkende) schoolverlaters over de aandacht die tijdens de opleiding besteed is aan vakkennis gepresenteerd. Opvallend is dat naarmate het genoten onderwijsniveau lager is, men meer behoefte heeft aan extra vakkennis. De afgestudeerden met een technische opleiding op HBO-niveau zijn in het algemeen redelijk tevreden over de aandacht die tijdens hun studie is besteed aan vakkennis. Dit duidt er op dat de kwaliteit van de HBO-opleidingen op dit punt door de afgestudeerden zelf als goed wordt ervaren. Gemiddeld genomen is $15 \%$ van de afgestudeerde HBO'ers met een technische opleidingsachtergrond van mening dat er meer aandacht had moeten worden besteed aan vaktheoretische kennis. Van de afgestudeerden in de richting bouwkunde/weg- en waterbouwkunde op HBO-niveau zijn er in vergelijking met de andere technisch opgeleide HBO'ers, iets meer ontevreden met de tijdens de studie aan vaktheoretische kennis bestede aandacht.

Tabel 2.19

Tevredenheid over de aandacht die in de opleiding besteed wordt aan vakkennis van schoolverlaters en recent afgestudeerden naar opleidingsniveau en -richting 1993

\begin{tabular}{|c|c|c|c|}
\hline Opleidingsniveau en -richting & $\begin{array}{c}\text { meer } \\
\%\end{array}$ & $\begin{array}{c}\text { Aandacht } \\
\text { evenveel } \\
\%\end{array}$ & $\underset{\%}{\operatorname{minder}}$ \\
\hline \multicolumn{4}{|l|}{ Hoger beroepsonderwijs } \\
\hline Technisch laboratorium & 15 & 84 & 1 \\
\hline $\begin{array}{l}\text { Technisch } \\
\text { bouwkunde/weg- en waterbouwkunde } \\
\text { werktuigbouwkunde } \\
\text { elektrotechniek/informatica }\end{array}$ & $\begin{array}{l}15 \\
20 \\
12 \\
16\end{array}$ & $\begin{array}{l}83 \\
78 \\
85 \\
83\end{array}$ & $\begin{array}{l}2 \\
2 \\
3 \\
2\end{array}$ \\
\hline \multicolumn{4}{|l|}{ Middelbaar beroepsonderwijs } \\
\hline Technisch laboratorium & 37 & 61 & 2 \\
\hline $\begin{array}{l}\text { Technisch } \\
\text { bouwkunde } \\
\text { weg- en waterbouwkunde } \\
\text { metaalkunde } \\
\text { fijnmechanische techniek } \\
\text { werktuigbouwkunde } \\
\text { motorvoertuigentechniek } \\
\text { elektrotechniek } \\
\text { procestechniek }\end{array}$ & $\begin{array}{r}38 \\
36 \\
41 \\
. \\
28 \\
39 \\
35 \\
.\end{array}$ & $\begin{array}{r}60 \\
61 \\
59 \\
. \\
66 \\
58 \\
61\end{array}$ & $\begin{array}{l}3 \\
3 \\
0 \\
. \\
. \\
5 \\
3 \\
4 \\
.\end{array}$ \\
\hline \multicolumn{4}{|l|}{ Voorbereidend beroepsonderwijs } \\
\hline $\begin{array}{l}\text { Technisch } \\
\text { bouwtechniek } \\
\text { installatietechniek } \\
\text { metaalkunde } \\
\text { motorvoertuigentechniek } \\
\text { elektrotechniek } \\
\text { grafische techniek } \\
\text { consumptieve techniek }\end{array}$ & $\begin{array}{r}43 \\
43 \\
41 \\
36 \\
51 \\
61\end{array}$ & $\begin{array}{r}51 \\
53 \\
57 \\
56 \\
38 \\
39\end{array}$ & $\begin{array}{r}5 \\
4 \\
2 \\
8 \\
11 \\
0\end{array}$ \\
\hline
\end{tabular}

Bron: RUBS/HBO-Monitor/ROA 
Op MBO-niveau blijkt dat gemiddeld genomen bijna $40 \%$ van de schoolverlaters achteraf gezien gewild zou hebben dat er tijdens de opleiding meer aandacht was besteed aan vakkennis. De schoolverlaters van de opleiding werktuigbouwkunde zijn op dit punt verhoudingsgewijs meer tevreden dan de andere MBO-schoolverlaters. Bij de technische opleidingen op VBO-niveau valt het hoge percentage schoolverlaters op dat van mening is dat er meer aandacht had moeten worden besteed aan vaktheoretische kennis. In het oog springend is dat maar liefst $61 \%$ van de schoolverlaters VBO consumptieve techniek hieraan graag meer aandacht had besteed. Ongeveer de helft van de schoolverlaters met een opleiding elektrotechniek op VBO-niveau is deze mening toegedaan.

Tabel 2.20

Tevredenheid over de aandacht die in de opleidng besteed wordt aan informatica/automatisering van schoolverlaters en recent afgestudeerden naar opleidingsniveau en -richting 1993

\begin{tabular}{|c|c|c|c|}
\hline Opleidingsniveau en -richting & $\begin{array}{c}\text { meer } \\
\%\end{array}$ & $\begin{array}{c}\text { Aandacht } \\
\text { evenveel } \\
\%\end{array}$ & $\underset{\%}{\operatorname{minder}}$ \\
\hline \multicolumn{4}{|l|}{ Hoger beroepsondenwijs } \\
\hline Technisch laboratorium & 27 & 66 & 7 \\
\hline $\begin{array}{l}\text { Technisch } \\
\text { bouwkunde/weg- en waterbouwkunde } \\
\text { werktuigbouwkunde } \\
\text { elektrotechniek/informatica }\end{array}$ & $\begin{array}{l}31 \\
41 \\
37 \\
26\end{array}$ & $\begin{array}{l}63 \\
53 \\
57 \\
69\end{array}$ & $\begin{array}{l}6 \\
6 \\
6 \\
6\end{array}$ \\
\hline \multicolumn{4}{|l|}{ Middelbaar beroepsonderwijs } \\
\hline Technisch laboratorium & 78 & 22 & 0 \\
\hline $\begin{array}{l}\text { Technisch } \\
\text { bouwkunde } \\
\text { weg- en waterbouwkunde } \\
\text { metaalkunde } \\
\text { fijnmechanische techniek } \\
\text { werktuigbouwkunde } \\
\text { motorvoertuigentechniek } \\
\text { elektrotechniek } \\
\text { procestechniek }\end{array}$ & $\begin{array}{r}71 \\
68 \\
84 \\
. \\
73 \\
61 \\
72 \\
.\end{array}$ & $\begin{array}{r}24 \\
26 \\
11 \\
. \\
25 \\
32 \\
24 \\
.\end{array}$ & $\begin{array}{l}5 \\
6 \\
5 \\
. \\
. \\
3 \\
7 \\
4 \\
.\end{array}$ \\
\hline \multicolumn{4}{|l|}{ Voorbereidend beroepsonderwijs } \\
\hline $\begin{array}{l}\text { Technisch } \\
\text { bouwtechniek } \\
\text { installatietechniek } \\
\text { metaalkunde } \\
\text { motorvoertuigentechniek } \\
\text { elektrotechniek } \\
\text { grafische techniek } \\
\text { consumptieve techniek }\end{array}$ & $\begin{array}{r}47 \\
38 \\
59 \\
59 \\
34 \\
59 \\
54\end{array}$ & $\begin{array}{r}32 \\
34 \\
33 \\
34 \\
21 \\
28\end{array}$ & $\begin{array}{r}21 \\
28 \\
\dot{8} \\
32 \\
20 \\
19\end{array}$ \\
\hline
\end{tabular}

Bron: RUBS/HBO-Monitor/ROA

Tabel 2.20 geeft aan in hoeverre de schoolverlaters en recent afgestudeerden tevreden zijn over de aandacht die tijdens hun studie is besteed aan informatica/automatisering. Het blijkt dat in het algemeen de schoolverlaters en recent afgestudeerden op dit punt veel minder tevreden zijn. De afgestudeerden met een technische opleiding op HBO-niveau zijn verhoudingsgewijs het meest tevreden over de aansluiting onderwijs-arbeidsmarkt wat betreft de kennis over informatica/automatisering, al zou ook hier bijna een derde van de afgestudeerden willen dat hieraan in hun opleiding meer aandacht was besteed. De richting (weg- en water)bouwkunde kent binnen het technisch onderwijs op HBO-niveau de meeste afgestudeerden die hieraan meer aandacht zouden willen besteden. Ongeveer $40 \%$ van de afgestudeer- 
den in deze richting deelt deze mening.

Vooral de schoolverlaters met een technische MBO-opleiding hebben in hun werk blijkbaar te maken met een gebrekkige aansluiting van de opleiding op de beroepspraktijk op het gebied van de kennis van automatisering. Gemiddeld is maar liefst bijna driekwart van de schoolverlaters ontevreden met de aandacht die tijdens hun studie is besteed aan informatica. Van de schoolverlaters weg- en waterbouwkunde is zelfs $84 \%$ van mening dat hieraan meer aandacht had moeten worden besteed. Ook van de schoolverlaters technisch laboratorium op MBO-niveau is het merendeel op dit punt ontevreden.

Tabel 2.21

Tevredenheid over de aandacht die in de opleiding besteed wordt aan het omgaan met apparatuur of materialen van schoolverlaters en recent afgestudeerden naar opleidingsniveau en -richting 1993

\begin{tabular}{|c|c|c|c|}
\hline Opleidingsniveau en -richting & $\begin{array}{c}\text { meer } \\
\%\end{array}$ & $\begin{array}{c}\text { Aandacht } \\
\text { evenveel } \\
\%\end{array}$ & $\begin{array}{c}\text { minder } \\
\%\end{array}$ \\
\hline \multicolumn{4}{|l|}{ Hoger beroepsonderwijs } \\
\hline Technisch laboratorium & 29 & 67 & 4 \\
\hline $\begin{array}{l}\text { Technisch } \\
\text { bouwkunde/weg- en waterbouwkunde } \\
\text { werktuigbouwkunde } \\
\text { elektrotechniek/informatica }\end{array}$ & $\begin{array}{l}28 \\
33 \\
30 \\
32\end{array}$ & $\begin{array}{l}67 \\
63 \\
65 \\
62\end{array}$ & $\begin{array}{l}5 \\
4 \\
5 \\
6\end{array}$ \\
\hline \multicolumn{4}{|l|}{ Middelbaar beroepsonderwijs } \\
\hline Technisch laboratorium & 68 & 32 & 0 \\
\hline $\begin{array}{l}\text { Technisch } \\
\text { bouwkunde } \\
\text { weg- en waterbouwkunde } \\
\text { metaalkunde } \\
\text { fijnmechanische techniek } \\
\text { werktuigbouwkunde } \\
\text { motorvoertuigentechniek } \\
\text { elektrotechniek } \\
\text { procestechniek }\end{array}$ & $\begin{array}{l}44 \\
50 \\
59 \\
.\end{array}$ & $\begin{array}{r}55 \\
47 \\
40 \\
.\end{array}$ & $\begin{array}{l}1 \\
1 \\
0 \\
. \\
i \\
1 \\
3 \\
2 \\
.\end{array}$ \\
\hline \multicolumn{4}{|l|}{ Voorbereidend beroepsonderwijs } \\
\hline $\begin{array}{l}\text { Technisch } \\
\text { bouwtechniek } \\
\text { installatietechniek } \\
\text { metaalkunde } \\
\text { motorvoertuigentechniek } \\
\text { elektrotechniek } \\
\text { grafische techniek } \\
\text { consumptieve techniek }\end{array}$ & $\begin{array}{l}60 \\
66 \\
62 \\
55 \\
69 \\
49\end{array}$ & $\begin{array}{r}36 \\
30 \\
37 \\
40 \\
28 \\
48\end{array}$ & $\begin{array}{l}4 \\
4 \\
1 \\
5 \\
3 \\
3\end{array}$ \\
\hline
\end{tabular}

Bron: RUBS/HBO-Monitor/ROA

Op VBO-niveau zijn vooral de schoolverlaters van de opleidingen metaalkunde en elektrotechniek van mening dat tijdens hun opleiding meer aandacht had mogen worden besteed aan informatica. Van de schoolverlaters van deze richtingen deelt ongeveer $60 \%$ deze mening. De schoolverlaters van de opleidingen bouwtechniek en motorvoertuigentechniek oordelen op dit punt het meest positief over de aansluiting onderwijs-arbeidsmarkt. Opvallend is echter dat een niet onaanzienlijk deel van de VBOschoolverlaters juist van mening is dat in de opleiding informatica minder aan bod had moeten komen. Blijkbaar komen zij in hun dagelijkse beroepspraktijk weinig in aanraking met (de gevolgen) van de voortschrijdende automatisering. 
Als derde kwalitatief aspect van de aansluiting onderwijs-arbeidsmarkt wordt het omgaan met apparatuur of materialen belicht. Tabel 2.21 geeft een beeld van de tevredenheid van schoolverlaters en recent afgestudeerden over de aandacht die hieraan tijdens hun studie is besteed. Van de afgestudeerden van het $\mathrm{HBO}$ in de technische richting is ongeveer $30 \%$ van mening dat meer aandacht had moeten worden besteed aan het omgaan met apparatuur of materialen. Het merendeel is tevreden met de hoeveelheid aandacht die ze hebben besteed aan dit aspect van de opleiding. Dit beeld geldt voor alle onderscheiden opleidingsrichtingen.

Ongeveer de helft van de technisch opgeleide MBO'ers had tijdens hun opleiding meer aandacht willen besteden aan apparatuur- en materialenkennis. Opvallend is daarbij de opleiding technisch laboratorium, waar maar liefst $68 \%$ van de schoolverlaters op dit punt ontevreden is. Van de schoolverlaters met een bouwkunde-opleiding op MBO-niveau zijn daarentegen relatief minder werkenden op dit punt ontevreden met door hen gevolgde opleiding, al gaat het hier altijd nog om bijna $40 \%$ van de werkende schoolverlaters.

De VBO'ers met een technische opleidingsachtergrond zijn verhoudingsgewijs het minst tevreden over hun in de opleiding opgedane kennis over apparatuur en materialen. Vooral de schoolverlaters met een opleiding VBO elektrotechniek zijn van mening dat hieraan meer aandacht had moeten worden besteed. Ongeveer $70 \%$ van de schoolverlaters met deze opleidingsachtergrond deelt deze mening. Daarentegen zijn de schoolverlaters VBO consumptieve techniek op dit punt redelijk tevreden, ofschoon ook hier meer dan de helft wat dit betreft een tekortkoming van de opleiding signaleert.

In tabel 2.22 wordt ten slotte een overzicht gegeven van de mate van tevredenheid van schoolverlaters en recent afgestudeerden over de aandacht die tijdens de studie besteed is aan praktijkoriëntatie of stage. Uit de tabel blijkt dat zowel op HBO- als op MBO-niveau ongeveer $40 \%$ van de schoolverlaters met een technische opleiding graag gezien had dat hieraan meer aandacht was gegeven. Van de afgestudeerden van de opleidingen HBO technisch laboratorium, HBO elektrotechniek/informatica, MBO motorvoertuigentechniek en MBO elektrotechniek zijn relatief veel mensen van mening dat er meer aandacht had moeten worden besteed aan een praktijkoriëntatie of stage. De schoolverlaters van de opleidingen MBO technisch laboratorium en werktuigbouwkunde zijn daarentegen vaker tevreden met de aandacht die hieraan in de opleiding is besteed.

De schoolverlaters van de technische opleidingen op VBO-niveau zijn verhoudingsgewijs het minst positief over de aandacht die in deze voorbereidende beroepsopleiding aan een praktijkoriëntatie of stage wordt geschonken. Gemiddeld is ongeveer $65 \%$ van deze schoolverlaters van mening dat meer aandacht zou moeten worden besteed aan het opdoen van praktijkervaring tijdens de opleiding. Vooral de schoolverlaters van de opleidingen elektrotechniek en consumptieve techniek hadden achteraf gezien tijdens hun opleiding hun kennis meer in de praktijk willen toepassen.

Concluderend kan worden gesteld dat naarmate het onderwijsniveau van de technisch opgeleide schoolverlaters en recent afgestudeerden lager is, hoe meer mensen van mening zijn dat in de opleiding meer aandacht had moeten worden besteed aan vakkennis, informatica, het omgaan met apparatuur en het opdoen van praktijkervaring. Vooral kennis van informatica blijkt, zelfs bij technisch opgeleiden een belangrijk knelpunt te zijn bij de overgang van het onderwijs naar de beroepspraktijk. Het meest schrijnend is deze problematiek bij de schoolverlaters die een MBO-opleiding hebben gevolgd. 
Tabel 2.22

Tevredenheid over de aandacht die in de opleiding besteed wordt aan praktijkoriëntatie of stage van schoolverlaters en recent afgestudeerden naar opleidingsniveau en -richting 1993

Opleidingsniveau en -richting

Aandacht

evenveel

$\% \quad \%$

minder

$\%$

Hoger beroepsondenwijs

Technisch laboratorium

55

0

Technisch

bouwkunde/weg- en waterbouwkunde

werktuigbouwkunde

42

elektrotechniek/informatica

Middelbaar beroepsonderwijs

\author{
Technisch laboratorium \\ Technisch \\ bouwkunde \\ weg- en waterbouwkunde \\ metaalkunde \\ fijnmechanische techniek \\ werktuigbouwkunde \\ motorvoertuigentechniek \\ elektrotechniek \\ procestechniek
}

Voorbereidend beroepsonderwijs

\author{
Technisch \\ bouwtechniek \\ installatietechniek \\ metaalkunde \\ motorvoertuigentechniek \\ elektrotechniek \\ grafische techniek \\ consumptieve techniek
}

= geen informatie i.v.m. te weinig waarnemingen 


\section{De toekomstige vraag naar technisch opgeleiden}

\subsection{Inleiding}

De totale vraag naar nieuwkomers, of ook wel het aantal baanopeningen, kan op twee gronden ontstaan. In de eerste plaats kan er sprake zijn van een uitbreidingsvraag, als gevolg van een groei van de werkgelegenheid. Een tweede component van de vraag is de vervangingsvraag. Deze ontstaat bijvoorbeeld als gevolg van de definitieve arbeidsmarktuitstroom van werkenden in verband met pensionering, VUT, arbeidsongeschiktheid of de tijdelijke terugtreding van de arbeidsmarkt bij met name vrouwen, samenhangend met de geboorte en opvoeding van de kinderen.

De werkgelegenheidsprognoses voor de technische opleidingen zijn gebaseerd op de middellangetermijn-bedrijfssectorprognoses van het Centraal Planbureau (CPB, 1993 en 1994). Het CPB heeft voor de middellange termijn twee scenario's opgesteld, het behoedzame en het gunstige scenario. Deze scenario's verschillen vooral in de veronderstellingen die worden gemaakt omtrent de ontwikkeling van de wereldeconomie, de beroepsbevolking en het arbeidsongeschiktheidsvolume. Het basisscenario dat in dit hoofdstuk wordt gepresenteerd, is gebaseerd op het behoedzame scenario. Dat scenario gaat uit van een matige groei van de (relevante) wereldhandel van ongeveer $4 \frac{1}{2} \%$ per jaar in de periode 1995 1998. Dit scenario resulteert in een economische groei van ongeveer $2 \%$ gemiddeld per jaar.

De verwachte werkgelegenheidsontwikkeling per bedrijfssector is eerst verbijzonderd naar beroepssegment en vervolgens naar opleidingsniveau en -richting. In paragraaf 3.2 worden de werkgelegenheidsontwikkelingen per sector besproken. Vervolgens wordt in paragraaf 3.3 ingegaan op de verwachte werkgelegenheidsontwikkeling voor technische beroepen en in paragraaf 3.4 op de vraagontwikkeling naar technisch opgeleiden die hieruit resulteert. In paragraaf 3.5 wordt vervolgens de vervangingsvraag voor de verschillende technische opleidingen gepresenteerd. Het hoofdstuk wordt in paragraaf 3.6 afgesloten met de prognose van het aantal baanopeningen dat voor de technische opleidingen voor de periode 1993-2000 volgens het basisscenario wordt verwacht.

\subsection{Werkgelegenheidsontwikkeling per bedrijfssector}

Tabel 3.1 geeft een overzicht van de feitelijke werkgelegenheidsontwikkeling per bedrijfssector over de periode 1990-1993 en de verwachte werkgelegenheidsontwikkeling over de periode 1993-2000. Terwijl in het begin van de jaren ' 90 nog een werkgelegenheidsgroei van in totaal gemiddeld 1,2\% per jaar is gerealiseerd, wordt voor de komende jaren nog slechts een jaarlijkse groei van $0,7 \%$ verwacht. Daarbij is overigens sprake van enkele aanzienlijke verschillen tussen de onderscheiden bedrijfssectoren.

In de periode 1990-1993 hebben de meeste industriële sectoren een negatieve werkgelegenheidsontwikkeling gekend. Alleen in de sectoren voedings- en genotmiddelenindustrie en in de bouw was er sprake van een geringe groei van de werkgelegenheid. De werkgelegenheid in de bouwsector zal naar verwachting ook in de komende periode licht blijven groeien. In de voedings- en genotmiddelenindustrie zal de werkgelegenheid volgens het CPB echter afnemen, voornamelijk als gevolg van de verdergaande rationalisatie van het produktieproces. De werkgelegenheidsdaling in de chemie en de metaal, elektrotechnische en transportmiddelenindustrie is in de afgelopen periode vrij omvangrijk geweest. Voor de periode 1993-2000 wordt daarentegen een groeiende werkgelegenheid in de chemische sector verwacht. In de metaal zal de werkgelegenheid echter nog steeds afnemen, maar in geringere mate dan in de afgelopen jaren. De sector energie zal naar verwachting weer gaan groeien. 
Tabel 3.1

Ontwikkeling van het aantal werkenden per bedrijfstak 1990-1993 en verwachte ontwikkeling 1993-2000 basisscenario (gemiddelde jaarlijkse groei)

\begin{tabular}{lrr}
\hline Bedrijfstak & $1990-1993$ & $\begin{array}{c}1993-2000 \\
\%\end{array}$ \\
\hline & $\%$ & $-0,5$ \\
Landbouw, visserij en bosbouw & $-0,7$ \\
Voedings- en genotmiddelenindustrie & $-0,4$ & 0,9 \\
Chemie & 0,5 & $-0,6$ \\
Metaal, elektrotechnische en transportmiddelenindustrie & $-1,3$ & $-0,4$ \\
Overige industrie (incl. kleding- en schoenenindustrie) & $-2,4$ & 0,8 \\
Energie & $-0,6$ & 0,4 \\
Bouw & $-0,6$ & 1,4 \\
Handel & 0,1 & 0,2 \\
Vervoer en communicatie & 2,5 & 1,4 \\
Kverige commerciële dienstverlening & 1,2 & 2,1 \\
Openbaar bestuur, politie, defensie en onderwijs & 2,9 & $-0,9$ \\
Totaal & 3,0 & 0,7 \\
\hline
\end{tabular}

Bron: CPB/ROA

In de commerciële diensten zet de groei van de afgelopen periode zich naar verwachting tot het jaar 2000, zij het in mindere mate, voort. De geringe groei van de werkgelegenheid in het bank- en verzekeringswezen is er de oorzaak van dat de groei iets afneemt in de overige commerciële dienstverlening. De qua werkgelegenheid snelst groeiende sector blijt ook de komende jaren de kwartaire dienstverlening. In de sector openbaar bestuur, politie, defensie en onderwijs blijft de werkgelegenheid daarentegen fors afnemen. De belangrijkste oorzaak voor deze ontwikkeling is de beoogde inkrimping van de krijgsmacht.

\subsection{Werkgelegenheidsontwikkeling voor de technische beroepen}

Tabel 3.2 geeft de verwachte werkgelegenheidsontwikkeling per beroepssegment weer. Een toe- of afname van de werkgelegenheid voor een beroep kan worden veroorzaakt door de groei of krimp van een bedrijfssector waar dat beroep veel voorkomt. Het is echter ook mogelijk dat de beroepenstructuur van een sector verandert. Het aandeel van een beroep binnen de sector verandert dan. Als gevolg van deze structuurverandering kan ook een toe- of afname van de werkgelegenheid voor dit beroep optreden. In deze paragraaf wordt voor de verschillende beroepen telkens aangegeven of de verwachtingen ten aanzien van de werkgelegenheidsontwikkelingen samenhangen met sectorale ontwikkelingen of juist door de veranderingen in de beroepenstructuur binnen de desbetreffende bedrijfssectoren (zie ook Borghans en Willems, 1994).

In de afgelopen periode is de werkgelegenheid voor technische beroepen met ongeveer $1,5 \%$ per jaar gedaald. Voor de komende periode wordt echter een werkgelegenheidsgroei van ongeveer $0,4 \%$ per jaar verwacht. Deze ontwikkeling hangt onder meer samen met het feit dat de voorspelde werkgelegenheidsdaling tot het jaar 2000 in de meeste industriële sectoren kleiner is dan de werkgelegenheidsdaling in deze sectoren gedurende de periode 1990-1993. Bij het vergelijken van de gerealiseerde groeicijfers over de afgelopen periode met de verwachte groei voor de komende periode moet rekening worden gehouden met het feit dat de gerealiseerde groeicijfers slechts op een korte periode betrekking hebben. Vanwege de conjunctuurgevoeligheid van veel technische beroepen kan het beeld van jaar tot jaar nogal variëren. 
De verwachte afname van de werkgelegenheid in de industriële sectoren is vooral merkbaar voor de technische beroepen op het laagste niveau ${ }^{9}$. De grootste werkgelegenheidsdaling, van $2,7 \%$ per jaar, wordt verwacht voor de 'lagere textielberoepen'. Voorbeelden van deze beroepen zijn kledingmakers, stoffeerders, schoen- en lederwarenmakers en produktiepersoneel in de textielindustrie. Een groot deel van de personen die in deze beroepen werkzaam zijn, heeft een baan in de sector 'overige industrie', waartoe ook de kleding- en schoenenindustrie wordt gerekend. Voor een belangrijk deel is de daling van de werkgelegenheid van deze beroepen dan ook toe te schrijven aan de dalende werkgelegenheid in deze sector.

Tabel 3.2

Ontwikkeling van het aantal werkenden per beroepssegment 1990-1993 en verwachte ontwikkeling van het aantal werkenden per beroepssegment 1993-2000 basisscenario (gemiddelde jaarlijkse groei)

\begin{tabular}{|c|c|c|c|}
\hline $\begin{array}{l}\text { ROA- } \\
\text { code }\end{array}$ & beroepssegment & $\begin{array}{c}1990-1993 \\
\%\end{array}$ & $\begin{array}{c}1993-2000 \\
\%\end{array}$ \\
\hline $\begin{array}{l}301 \\
302 \\
303 \\
311 \\
321 \\
331 \\
341 \\
351 \\
361 \\
362 \\
363 \\
371 \\
372 \\
373 \\
381 \\
391 \\
392 \\
393\end{array}$ & $\begin{array}{l}\text { Lagere technische, ambachts- en industrieberoepen } \\
\text { Middelbare technische, ambachts- en industrieberoepen } \\
\text { Hogere technische, ambachts- en industrieberoepen } \\
\text { Lagere voedings- en genotmiddelenberoepen } \\
\text { Lagere textielberoepen } \\
\text { Lagere hout- en papierberoepen } \\
\text { Lagere grafische beroepen } \\
\text { Lagere chemische beroepen } \\
\text { Lagere metaalberoepen } \\
\text { Middelbare metaalberoepen } \\
\text { Hogere metaalberoepen } \\
\text { Lagere elektrotechnische beroepen } \\
\text { Middelbare elektrotechnische beroepen } \\
\text { Hogere elektrotechnische beroepen } \\
\text { Lagere bouwmaterialen-, glas- en aardewerkberoepen } \\
\text { Lagere bouw- en installatieberoepen } \\
\text { Middelbare bouw- en installatieberoepen } \\
\text { Hogere bouw-en installatieberoepen }\end{array}$ & $\begin{array}{r}3,2 \\
-2,1 \\
-2,3 \\
-5,9 \\
-4,8 \\
1,4 \\
-2,3 \\
0,0 \\
-1,0 \\
-3,2 \\
3,6 \\
-1,3 \\
-0,3 \\
9,3 \\
-4,8 \\
-5,4 \\
7,1 \\
13,3\end{array}$ & $\begin{array}{r}0,8 \\
2,0 \\
1,2 \\
-1,1 \\
-2,7 \\
-0,5 \\
1,3 \\
0,1 \\
-0,8 \\
-0,1 \\
0,6 \\
-1,1 \\
0,3 \\
0,2 \\
-2,6 \\
0,1 \\
-0,4 \\
1,7\end{array}$ \\
\hline 393 & Totaal technische beroepen & $-1,5$ & 0,4 \\
\hline
\end{tabular}

\section{Bron: ROA/CBS}

Ook voor de 'lagere bouwmaterialen-, glas- en aardewerkberoepen' zal naar verwachting de werkgelegenheid fors blijven afnemen. De belangrijkste sectoren voor deze beroepen zijn de chemie, de metaal en de overige industrie. Alleen in de chemie wordt voor de komende jaren een werkgelegenheidsgroei verwacht. Het aandeel van de 'lagere bouwmaterialen-, glas- en aardewerkberoepen' binnen de chemische industrie zal echter dermate dalen dat per saldo niet wordt geprofiteerd van de gunstige ontwikkeling die de chemische industrie doormaakt. Dat geldt ook voor de 'lagere chemische beroepen'. Het merendeel van de personen met dit beroep is werkzaam in de chemie. Door een negatieve ontwikkeling van deze beroepen binnen de sector chemie wordt het positieve effect van de werkgelegenheidsgroei in de sector teniet gedaan. De werkgelegenheid voor de 'lagere chemische beroepen' zal, evenals in de afgelopen periode, ongeveer gelijk blijven.

De werkgelegenheid voor de 'lagere voedings- en genotmiddelenberoepen' zal gemiddeld met $1,1 \%$ per jaar afnemen. Deze afname vindt zijn oorsprong in de afnemende werkgelegenheid in de voedings- en genotmiddelenindustrie waar de meeste personen met deze beroepen, werkzaam zijn. Binnen de voedings- en genotmiddelenindustrie maken deze beroepen echter ook een ongunstige ontwikkeling door.

9. Dit zijn de beroepen waarvan het derde cijfer in de code een 1 is. 
De belangrijkste bedrijfssector voor de 'lagere hout- en papierberoepen' is de bouw. Dit betreft dan met name timmerlieden. Binnen de bouwsector zal de werkgelegenheid voor dit beroep naar verwachting echter afnemen zodat nauwelijks wordt geprofiteerd van de voor deze sector verwachte werkgelegenheidsgroei. Ook in de sector 'overige industrie' zijn veel mensen in deze beroepen werkzaam. Dat zijn dan met name houtwaren-, papier- en kartonmakers. In deze sector maakt dit beroep eveneens een negatieve werkgelegenheidsontwikkeling door. De positieve werkgelegenheidsontwikkeling van de afgelopen jaren zal zich dan ook niet voortzetten. In totaal zal de werkgelegenheid voor de 'lagere houten papierberoepen' naar verwachting met ongeveer $0,5 \%$ per jaar dalen.

Een positieve uitzondering op het totaalbeeld van de lagere technische beroepen vormen de 'lagere grafische beroepen'. Hiertoe worden onder meer de drukkers en het produktiepersoneel in de grafische industrie gerekend. Terwijl de werkgelegenheid voor deze beroepen in de afgelopen periode nog is afgenomen, wordt voor de komende periode een stijging van de werkgelegenheid van 1,3\% gemiddeld per jaar verwacht. Voor de 'lagere technische, ambachts-, en industrieberoepen', dat zijn met name heftruck- en hefvorkchauffeurs en machinisten bouw en industrie, wordt een lichte groei van de werkgelegenheid met ongeveer $0,8 \%$ per jaar verwacht. De 'middelbare technische, ambachts-, en industrieberoepen' zullen daarentegen naar verwachting een forse groei van $2,0 \%$ per jaar doormaken. Deze beroepen, voor het merendeel leidinggevenden in de industrie, zijn vrijwel in alle bedrijfssectoren ruim vertegenwoordigd. De grootste groei maakt dit beroep door in de sector overige commerciële dienstverlening. De 'middelbare technische, ambachts- en industrieberoepen' profiteren niet alleen van de toenemende groei van deze sector, ook neemt het belang van deze beroepen binnen de sector toe. De werkgelegenheid voor de 'hogere technische, ambachts-, en industrieberoepen', zoals bètaonderzoekers en technische vakspecialisten, zal naar verwachting met ongeveer 1,2\% per jaar groeien. Het merendeel van de werkenden in deze beroepen is werkzaam in de commerciële en nietcommerciële dienstverlening. Opmerkelijk is echter dat de beroepen de grootste groei doormaken in de metaalindustrie. Het beroep maakt binnen de deze sector een dermate positieve ontwikkeling door dat de negatieve effecten van de dalende werkgelegenheid in deze sector worden gecompenseerd.

De werkgelegenheidsdaling die voor de 'lagere metaalberoepen', zoals lassers, machinebankwerkers, en onderhoudsmonteurs, wordt verwacht, is niet alleen toe te schrijven aan de dalende werkgelegenheid in de metaalindustrie, maar wordt ook veroorzaakt door de ongunstige ontwikkeling die deze beroepen binnen deze sector doormaken. Deze ongunstige werkgelegenheidsontwikkeling in de metaalindustrie wordt slechts in geringe mate gecompenseerd door de toename van de werkgelegenheid voor deze beroepen in de sectoren handel en overige commerciële dienstverlening. Voor de 'middelbare metaalberoepen', dat zijn bijvoorbeeld automonteurs en middelbare werktuigbouwkundigen, wordt een lichte werkgelegenheidsdaling van ongeveer $0,1 \%$ per jaar verwacht. De belangrijkste sector voor deze beroepen is de commerciële dienstverlening. De beroepen zullen echter nauwelijks profiteren van de verwachte groei van deze sector. Binnen deze sector zal de werkgelegenheid voor 'middelbare metaalberoepen' namelijk fors afnemen. Ook binnen de metaal, elektrotechnische en transportmiddelenindustrie maken deze beroepen een ongunstige ontwikkeling door. De werkgelegenheid voor de 'hogere metaalberoepen', dat zijn hogere werktuigbouwkundigen, geeft daarentegen een heel ander beeld te zien. Naar verwachting zal de werkgelegenheid voor hogere werktuigbouwkundigen met ongeveer $0,6 \%$ per jaar toenemen. Het beroep lijdt nauwelijks onder de ongunstige ontwikkeling van zijn belangrijkste sector: de metaal, elektrotechnische en transportmiddelenindustrie.

Omdat meer dan de helft van de personen met een 'lager elektrotechnisch beroep', zoals monteurs van elektrotechnische produkten, in de metaal, elektrotechnische en transportmiddelenindustrie werken, is het niet verwonderlijk dat voor dit beroep een forse werkgelegenheidsdaling wordt verwacht. De 
'middelbare elektrotechnische beroepen' (bijvoorbeeld elektriciens en elektromonteurs) zullen naar verwachting in de komende jaren, in tegenstelling tot de afgelopen jaren, te maken krijgen met een lichte werkgelegenheidstoename van ongeveer $0,3 \%$ per jaar. De belangrijkste sectoren voor deze beroepen zijn de bouw en de metaal. In de metaal zal het aantal werkenden in deze beroepen ongeveer gelijk blijven. In de bouw zal het aantal iets toenemen. De 'hogere elektrotechnische beroepen' zullen naar verwachting tot het jaar 2000 met ongeveer $0,2 \%$ per jaar groeien.

Verwacht wordt dat de 'lagere bouw- en installatieberoepen' slechts in geringe mate zullen profiteren van de werkgelegenheidstoename in de bouw. De verwachte werkgelegenheidstoename voor bouwvakkers is ongeveer $0,1 \%$ per jaar. Voor de 'middelbare bouw- en installatieberoepen', waaronder bouwkundige technici, opzichters en werkvoorbereiders, zal de werkgelegenheid tot het jaar 2000 naar verwachting licht dalen. De verwachte werkgelegenheidsgroei voor de 'hogere bouw- en installatieberoepen', bijvoorbeeld architecten en geodeten, is daarentegen vrij hoog. Deze groei wordt vooral veroorzaakt door de groei van de sector commerciële dienstverlening. In deze sector is ongeveer de helft van de personen in één van de 'hogere bouw- en installatieberoepen' werkzaam.

\subsection{Uitbreidingsvraag voor de technische opleidingen}

De verwachte werkgelegenheidsontwikkelingen per beroepssegment leiden tot een uitbreidingsvraag voor de technische opleidingen. Een verwachte positieve uitbreidingsvraag naar een bepaalde opleiding leidt echter niet per definitie tot een gelijke toename van de werkgelegenheid voor deze opleiding. De uiteindelijke werkgelegenheidsontwikkeling voor een opleiding is afhankelijk van zowel vraag- als aanbodfactoren. Tabel 3.3 geeft de verwachte uitbreidingsvraag naar opleidingsniveau en -richting ${ }^{10}$. Deze uitbreidingsvraag kan enerzijds het gevolg zijn van de werkgelegenheidsontwikkeling van een bepaald beroepssegment en anderzijds van de vraagontwikkeling binnen een beroepssegment. In het laatste geval is er sprake van upgrading van de werkgelegenheid.

De verwachte uitbreidingsvraag is relatief het grootst voor de technische opleidingen op WO-niveau. Binnen deze opleidingen wordt de richting bouwkunde/civiele techniek met de grootste vraagtoename geconfronteerd. Dat is nauwelijks verwonderlijk gezien de gunstige werkgelegenheidsontwikkeling die voor de 'hogere bouw- en installatieberoepen' wordt verwacht. Een belangrijk deel van de uitbreidingsvraag voor de richting elektrotechniek/informatica doet zich voor in de 'hogere administratieve beroepen'. Tot deze beroepen worden naast economen en accountants ook systeemanalisten, -programmeurs en -beheerders gerekend. Niet alleen profiteert de opleiding WO elektrotechniek/informatica van de toenemende werkgelegenheid voor deze beroepen, ook binnen deze beroepen neemt de vraag naar personen met deze opleiding toe. Tot voor kort kwamen mensen met uiteenlopende opleidingsachtergronden in de computerbranche terecht, mede omdat er nog geen speciaal op deze beroepen gerichte dagopleiding was. Nu die er wel is en tevens de groei van de markt voor deze beroepen wat afneemt, worden er in deze sector vaak striktere opleidingsvereisten gesteld dan in het verleden. Verder profiteert de opleiding van de toenemende werkgelegenheid in de 'hogere elektrotechnische beroepen'.

10. Helaas kan hierbij geen vergelijking worden gemaakt met de periode 1990-1993, aangezien de naar opleidingsrichting verbijzonderde cijfers pas sinds 1992 beschikbaar zijn. 
Tabel 3.3

Verwachte uitbreidingsvraag technische opleidingen naar opleidingsniveau en -richting 1993-2000 basisscenario (totaal aantal en gemiddeld jaarlijks percentage)

$\begin{array}{ll}\text { Opleidingsniveau en -richting } \quad \text { aantal } & \%\end{array}$

Wetenschappelijk onderwijs

Wiskunde en natuurwetenschappen

$\begin{array}{rl}6.600 & 2,5 \\ 15.000 & 3,3 \\ 5.300 & 3,6 \\ 2.400 & 3,6 \\ 2.900 & 3,3\end{array}$

Technisch

bouwkunde/civiele techniek

werktuigbouwkunde

2.900

$\%$

elektrotechniek/informatica

Technisch laboratorium

bouwkunde/weg- en waterbouwkunde

werktuigbouwkunde

elektrotechniek/informatica

Middelbaar beroepsonderwijs

Technisch laboratorium

Technisch

bouwkunde

weg-en waterbouwkunde

metaalkunde

1.400

2.600

500

4.700

werktuigbouwkunde

3.000

motorvoertuigentechniek

6.900

1.100

elektrotechniek

0,8

0,9

1,0

0,6

0,6

procestechniek

$\begin{array}{rr}-29.800 & -0,9 \\ -6.800 & -0,7 \\ -300 & -0,4 \\ -10.200 & -1,1 \\ -2.900 & -0,9 \\ -4.600 & -1,1 \\ -100 & -0,2 \\ -1.400 & -0,8\end{array}$

Bron: ROA

De verwachte uitbreidingsvraag voor de richting werktuigbouwkunde is vooral terug te voeren op de groei van de 'middelbare technische, ambachts- en industrie beroepen' en de 'hogere metaalberoepen'. Ook deze opleiding profiteert echter enigszins van de verwachte werkgelegenheidstoename voor 'hogere administratieve beroepen'. De uitbreidingsvraag voor de opleidingen wiskunde en natuurwetenschappen blijft naar verwachting wat achter bij de vraag naar WO-technici. Een groot deel van de personen met een opleiding wis- of natuurkunde is werkzaam in 'hogere onderwijskundige beroepen'. De werkgelegenheid voor deze beroepen zal in de komende jaren naar verwachting min of meer gelijk blijven (zie ook Alessie e.a., 1992). 
Voor de technische opleidingen op HBO-niveau wordt een redelijk grote uitbreidingsvraag van $2,1 \%$ per jaar verwacht. De uitbreidingsvraag is voor alle technische richtingen op HBO-niveau vrijwel gelijk. De oorzaken van de toenemende behoefte aan arbeidskrachten verschillen echter wel per richting. Overigens geldt voor alle opleidingen dat zij in meer of mindere mate profiteren van de groei van de 'middelbare technische, ambachts- en industrieberoepen'.

De richting HBO bouwkunde/weg- en waterbouwkunde profiteert met name van de verwachte groei van de 'hogere bouw- en installatieberoepen'. De vraag naar deze opleiding groeit echter ook sterk in de 'middelbare bouw- en installatieberoepen'. Daar de werkgelegenheid voor dit beroep ongeveer gelijk blijft, gaat dit ten koste van andere opleidingen binnen dit beroepssegment. De groei van de opleiding HBO werktuigbouwkunde hangt bijna geheel samen met de groei van de 'middelbare technische, ambachts- en industrieberoepen'. Voor de richting elektrotechniek/informatica op HBO-niveau geldt, evenals voor dezelfde richting op WO-niveau, dat de 'hogere administratieve beroepen' een belangrijke rol spelen bij de toename van de vraag naar deze richting.

De verwachte groei van de vraag naar personen met de opleiding HBO technisch laboratorium vindt zijn oorsprong in de gunstige werkgelegenheidsontwikkeling voor 'middelbare technische, ambachts- en industrieberoepen'. In dit beroepssegment is een groot deel van de mensen met een technische laboratoriumopleiding werkzaam. De verwachte groei van de 'hogere medische en paramedische beroepen', zoals radiologische, medische en biologische laboranten, en de 'hogere administratieve beroepen' speelt echter ook een rol.

Met een uitbreidingsvraag van $0,8 \%$ gemiddeld per jaar doen de opleidingen op MBO-niveau het duidelijk minder goed. Absoluut gezien is de verwachte groei van de vraag echter wel vrij hoog. Alle richtingen op MBO-niveau profiteren van de verwachte toename van de 'middelbare technische, ambachts- en industrieberoepen. Wel geldt dat het belang van de technische opleidingen op MBOniveau voor dit beroep afneemt. De positie van de opleidingen op MBO-niveau verzwakt ten opzichte van de opleidingen op HBO-niveau.

Zowel de richting bouwkunde als de richting weg- en waterbouwkunde op MBO-niveau profiteren van de verwachte werkgelegenheidstoename voor de 'lagere bouw- en installatieberoepen'. Bovendien zal het belang van deze opleidingen binnen dat beroepssegment toenemen. Het belang van de richting metaalkunde in de 'middelbare metaalberoepen' zal in de komende tijd naar verwachting ook toenemen. De vraagimpuls die hier van uitgaat wordt echter grotendeels teniet gedaan door de matige werkgelegenheidperspectieven voor de 'middelbare metaalberoepen'. De uitbreidingsvraag voor de richtingen werktuigbouwkunde en fijnmechanische techniek is bijna geheel afhankelijk van de werkgelegenheidsontwikkeling voor de 'lagere en middelbare technische, ambachts- en industrieberoepen'. De richting motorvoertuigentechniek zal binnen de 'middelbare metaalberoepen', tegen de algehele ontwikkeling van deze beroepen in, een relatief sterke groei doormaken. De opleiding elektrotechniek zal naar verwachting profiteren van de gunstige werkgelegenheidsontwikkeling, die wordt verwacht voor de 'middelbare elektrotechnische beroepen'. Bovendien zal deze opleiding in de toekomst belangrijker worden voor deze beroepen. Bij de opleiding MBO procestechniek valt op dat de toenemende vraag naar arbeidskrachten met deze opleiding grotendeels voortkomt door het toenemende belang van deze opleiding voor de 'lagere chemische beroepen'.

De vraag naar mensen met een technische laboratoriumopleiding op MBO-niveau zal naar verwachting met ongeveer $1,2 \%$ per jaar groeien. Deze groei is bijna geheel toe te schrijven aan de verwachte groei van de 'middelbare technische, ambachts- en industrieberoepen'. Bijna de helft van de mensen met 
deze opleiding is in deze beroepen werkzaam. Wel verliest de opleiding binnen deze beroepen terrein ten gunste van andere opleidingen.

Alle technische opleidingen op VBO-niveau zullen naar verwachting in de komende tijd geconfronteerd worden met een negatieve uitbreidingsvraag. De richtingen metaalkunde, elektrotechniek en motorvoertuigentechniek zullen relatief de grootste werkgelegenheidsdaling ondervinden. Dit hangt vooral samen met de dalende werkgelegenheid in de 'lagere elektrotechnische beroepen' en de 'lagere metaalberoepen'. Bovendien worden in deze beroepen steeds vaker MBO'ers in plaats van VBO'ers gevraagd. Voor de richtingen bouwtechniek en installatietechniek op VBO-niveau neemt de werkgelegenheid relatief minder dan gemiddeld af. Dat kan worden verklaard door de positieve werkgelegenheidsontwikkeling voor de 'lagere bouw- en installatieberoepen'. De toename van de vraag naar beide opleidingen is echter geringer dan op grond van de ontwikkeling van de beroepenstructuur zou mogen worden verwacht. Ook hier gaat de vraag naar VBO'ers ten koste van die naar MBO'ers. De opleiding grafische techniek profiteert maar matig van de gunstige ontwikkelingen voor de 'lagere grafische beroepen'. Het belang van deze opleiding in dit beroep zal in de toekomst afnemen. Per saldo zal de vraag naar arbeidskrachten met een grafische opleiding op VBO-niveau in de 'lagere grafische beroepen' wel toenemen. Deze groei wordt echter teniet gedaan door een werkgelegenheidsdaling in andere beroepen waar mensen met deze opleiding werkzaam zijn. De verwachte werkgelegenheidsdaling voor de richting consumptieve techniek is bijna geheel toe te schrijven aan de verwachte negatieve ontwikkelingen voor de 'lagere voedings- en genotmiddelenberoepen'.

\subsection{Vervangingsvraag}

Naast de uitbreidingsvraag is ook de vervangingsvraag van belang voor nieuwkomers op de arbeidsmarkt. De vervangingvraag is de vraag die ontstaat als gevolg van het personeelsverloop door bijvoorbeeld (vervroegde) pensionering, arbeidsongeschiktheid en de uittreding van gehuwde vrouwen. Tabel 3.4 laat zien dat de vervangingsvraag in het algemeen een veel belangrijkere component is van het totaal aantal baanopeningen voor nieuwkomers dan de uitbreidingsvraag. De vervangingsvraag voor de opleidingen op WO- en HBO-niveau is relatief wat hoger dan voor de opleidingen op MBO- en VBOniveau. Opvallend is echter dat in tegenstelling tot de uitbreidingsvraag de spreiding tussen de opleidingsniveaus gering is. Dit betekent dat de vervangingsvraag een sterk stabiliserend effect heeft op de totale vraag naar nieuwkomers op de arbeidsmarkt (zie ook De Grip, Meijboom en Willems, 1994). Tussen de verschillende opleidingsrichtingen bestaan er wel enkele belangrijke verschillen in de vervangingsvraag.

Naar verwachting worden in de periode tot het jaar 2000 ongeveer 7.000 werkenden met een opleiding in de wiskunde of natuurwetenschappen door nieuwkomers vervangen. Dit komt overeen met jaarlijks $2,5 \%$ van het aantal werkenden. Voor de technische opleidingen op WO-niveau wordt een vervangingsvraag van gemiddeld $3,3 \%$ per jaar verwacht. Voor de technische opleidingen op HBO-niveau is de vervangingsvraag iets lager, namelijk $3,0 \%$ per jaar. Opvallend daarbij is dat de vervangingsvraag voor de verschillende opleidingsrichtingen bij beide opleidingsniveaus een vrijwel gelijk beeld laat zien. De opleidingen elektrotechniek/informatica zullen naar verwachting zowel op WO- als op HBO-niveau een verhoudingsgewijs lage vervangingsvraag hebben. Dat hangt onder meer samen met de relatief jonge leeftijdsopbouw van de werkenden met deze opleidingen (zie ook hoofdstuk 2, tabel 2.3). In de afgelopen jaren is de arbeidsmarktinstroom vanuit deze opleidingen vrij groot geweest, waardoor het personeelsverloop als gevolg van pensionering in de komende jaren in verhouding gering zal zijn. Voor de opleidingen WO bouwkunde/civiele techniek en HBO bouwkunde/weg- en waterbouwkunde zal de vervangingsvraag naar verwachting relatief groot zijn, daar een relatief groot deel van de werkenden 
met deze opleidingsachtergrond ouder is dan 50 jaar.

Tabel 3.4

Verwachte vervangingsvraag technische opleidingen naar opleidingsniveau en -richting 1993-2000 basisscenario (totaal aantal en gemiddeld jaarlijks percentage)

\begin{tabular}{|c|c|c|}
\hline Opleidingsniveau en -richting & aantal & $\%$ \\
\hline \multicolumn{3}{|l|}{ Wetenschappelijk onderwijs } \\
\hline Wiskunde en natuurwetenschappen & 7.000 & 2,5 \\
\hline $\begin{array}{l}\text { Technisch } \\
\text { bouwkunde/civiele techniek } \\
\text { werktuigbouwkunde } \\
\text { elektrotechniek/informatica }\end{array}$ & $\begin{array}{r}15.500 \\
5.800 \\
2.400 \\
2.700\end{array}$ & $\begin{array}{l}3,3 \\
3,9 \\
3,5 \\
2,9\end{array}$ \\
\hline \multicolumn{3}{|l|}{ Hoger beroepsonderwijs } \\
\hline Technisch laboratorium & 3.800 & 1,9 \\
\hline $\begin{array}{l}\text { Technisch } \\
\text { bouwkunde/weg- en waterbouwkunde } \\
\text { werktuigbouwkunde } \\
\text { elektrotechniek/informatica }\end{array}$ & $\begin{array}{r}27.100 \\
8.900 \\
6.400 \\
6.500\end{array}$ & $\begin{array}{l}3,0 \\
3,5 \\
2,8 \\
2,3\end{array}$ \\
\hline \multicolumn{3}{|l|}{ Middelbaar beroepsonderwijs } \\
\hline Technisch laboratorium & 2.100 & 2,1 \\
\hline $\begin{array}{l}\text { Technisch } \\
\text { bouwkunde } \\
\text { weg- en waterbouwkunde } \\
\text { metaalkunde } \\
\text { fijnmechanische techniek } \\
\text { werktuigbouwkunde } \\
\text { motorvoertuigentechniek } \\
\text { elektrotechniek } \\
\text { procestechniek }\end{array}$ & $\begin{array}{r}130.800 \\
33.900 \\
2.800 \\
12.300 \\
3.900 \\
15.300 \\
11.100 \\
20.900 \\
1.900\end{array}$ & $\begin{array}{l}2,5 \\
2,7 \\
1,9 \\
2,7 \\
3,4 \\
2,3 \\
2,3 \\
2,0 \\
1,3\end{array}$ \\
\hline \multicolumn{3}{|l|}{ Voorbereidend beroepsonderwijs } \\
\hline $\begin{array}{l}\text { Technisch } \\
\text { bouwtechniek } \\
\text { installatietechniek } \\
\text { metaalkunde } \\
\text { motorvoertuigentechniek } \\
\text { elektrotechniek } \\
\text { grafische techniek } \\
\text { consumptieve techniek }\end{array}$ & $\begin{array}{r}99.500 \\
25.300 \\
1.500 \\
28.400 \\
7.700 \\
9.300 \\
1.800 \\
3.500\end{array}$ & $\begin{array}{l}2,7 \\
2,4 \\
1,7 \\
2,7 \\
2,3 \\
2,0 \\
3,1 \\
2,1\end{array}$ \\
\hline
\end{tabular}

Bron: ROA

Voor de opleidingen HBO technisch laboratorium en MBO technisch laboratorium wordt, ondanks het hoge percentage vrouwen onder de werkenden, een relatief lage vervangingsvraag verwacht. Ook voor deze opleidingen geldt dat de gemiddelde leeftijd van de werkenden vrij jong is. In absolute aantallen is de verwachte vervangingsvraag het grootst voor de technische opleidingen op MBO-niveau. Dat is echter niet zo verwonderlijk daar relatief veel arbeidskrachten een dergelijke opleidingsachtergrond hebben. Relatief gezien bedraagt de vervangingsvraag voor de technische opleidingen op MBO-niveau naar verwachting ongeveer $2,5 \%$ per jaar. Binnen deze opleidingen is de spreiding in de vervangingsvraag vrij groot. Voor de opleiding MBO procestechniek wordt een relatief lage vervangingsvraag verwacht. Deze bedraagt slechts $1,3 \%$ per jaar. Dat is voor een belangrijk deel toe te schrijven aan het 
feit dat ruim drie kwart van de werkenden met deze opleiding jonger dan 40 jaar is. De verwachte vervangingsvraag voor de opleiding fijnmechanische techniek is vrij groot vergeleken met de andere technische opleidingen op MBO-niveau, namelijk ongeveer 3,4\% per jaar.

De vervangingsvraag voor de technische opleidingen op VBO-niveau wijkt relatief gezien naar verwachting niet veel af van de vervangingsvraag voor de technische opleidingen op MBO-niveau. Bij de richting installatietechniek, waar bijna $75 \%$ van de werkenden jonger is dan 40 jaar is, zal de vervangingsvraag relatief laag zijn. Ook voor de opleidingen VBO elektrotechniek en VBO consumptieve techniek is de vervangingsvraag in vergelijking met de andere technische opleidingen gering. De relatief hoogste vervangingsvraag binnen de opleidingen op VBO-niveau wordt verwacht voor de opleiding VBO grafische techniek. Wellicht hangt dit samen met het feit dat relatief gezien wat meer vrouwen een dergelijke opleidingsachtergrond hebben.

\subsection{Baanopeningen}

Tabel 3.5 geeft de verwachte baanopeningen naar opleidingsniveau- en richting. Het verwachte aantal baanopeningen per opleiding bestaat uit de (positieve) uitbreidingsvraag en de vervangingsvraag. Voor de technische opleidingen op universitair niveau zijn de uitbreidingsvraag en de vervangingsvraag ongeveer even belangrijk voor het totaal aantal baanopeningen. Voor de technische opleidingen op HBO- en MBO-niveau is de vervangingsvraag over het algemeen de belangrijkste component. Voor het VBO technisch wordt het totaal aantal baanopeningen zelfs geheel door de vervangingsvraag bepaald.

Het verwachte aantal baanopeningen voor de technische opleidingen op WO-niveau bedraagt ruim 30.000. Met name voor de opleiding WO bouwkunde/civiele techniek is het aantal baanopeningen naar verwachting relatief hoog, namelijk ongeveer $6,8 \%$ per jaar. Voor de studies wiskunde en natuurwetenschappen blijft het aantal baanopeningen wat achter ten opzichte van de overige technische studies op universitair niveau. Zowel de vervangingsvraag als de uitbreidingsvraag zijn voor dit opleidingstype wat lager.

Voor de technische opleidingen op HBO-niveau bedraagt het aantal baanopeningen bijna 46.000 , hetgeen overeenkomt met jaarlijks $4,8 \%$ van het aantal werkenden met deze opleiding. Bij de opleiding HBO elektrotechniek/informatica blijkt het aantal baanopeningen, vooral vanwege de lagere vervangingsvraag, relatief gezien iets achter te blijven. Het aantal baanopeningen voor HBO technisch laboratorium bedraagt in de periode $1993-2000$ bijna 8.500 .

Absoluut gezien is het aantal baanopeningen het hoogst voor de technische opleidingen op MBOniveau. De totale vraag naar nieuwkomers op de arbeidsmarkt bedraagt naar verwachting ruim 170.000. Dit komt neer op een gemiddeld jaarlijks percentage van $3,2 \%$. Vooral bij de opleiding MBO fijnmechanische techniek wordt een relatief hoog percentage baanopeningen verwacht. Bij de MBO-opleidingen elektrotechniek en procestechniek is de totale vraag naar nieuwkomers lager dan het gemiddelde.

Het relatief laagste aantal baanopeningen wordt verwacht voor het VBO technisch. Vooral voor de opleiding VBO installatietechniek is het aantal baanopeningen naar verwachting zeer laag. De opleiding grafische techniek op VBO-niveau vormt een positieve uitzondering. Het jaarlijks percentage baanopeningen bedraagt voor deze opleiding gemiddeld $3,1 \%$. In totaal zullen er voor deze opleidingscategorie circa 1.800 arbeidsplaatsen voor nieuwkomers beschikbaar komen. 
Tabel 3.5

Verwachte baanopeningen technische opleidingen naar opleidingsniveau en -richting 1993-2000 basisscenario (totaal aantal en gemiddeld jaarlijks percentage)

Opleidingsniveau en -richting

aantal

$\%$

Wetenschappelijk onderwijs

Wiskunde en natuurwetenschappen

13.600

4,8

Technisch

30.500

6,2

bouwkunde/civiele techniek

11.100

6,8

werktuigbouwkunde

4.800

6,6

elektrotechniek/informatica

5.600

Hoger beroepsonderwijs

Technisch laboratorium

8.400

Technisch

45.700

14.200

4,8

bouwkunde/weg- en waterbouwkunde

11.100

5,1

werktuigbouwkunde

12.700

4,7

elektrotechniek/informatica

4,1

Middelbaar beroepsonderwijs

Technisch laboratorium

3.000

Technisch

170.600

44.300

bouwkunde

4.200

14.900

metaalkunde

4.400

20.000

14.100

werktuigbouwkunde

27.800

3.000

3,2

2,9

3,2

4,3

motorvoertuigentechniek

elektrotechniek

3,0

2,8

procestechniek

Voorbereidend beroepsonderwijs

Technisch

99.500

25.300

2,7

bouwtechniek

1.500

installatietechniek

28.400

7.700

motorvoertuigentechniek

9.300

1.800

3.500

2,4

1,7

2,7

2,3

elektrotechniek

2,0

grafische techniek

3,1

consumptieve techniek

Bron: ROA 


\section{De toekomstige instroom van technisch opgeleide schoolverlaters}

\subsection{Inleiding}

De in het vorige hoofdstuk besproken uitbreidings- en vervangingsvraag geven de verwachte ontwikkelingen aan de vraagkant van de arbeidsmarkt voor technisch opgeleiden weer. Tegenover deze behoefte aan schoolverlaters staan aan de aanbodzijde van de arbeidsmarkt de toekomstige ontwikkelingen van de instroom van schoolverlaters met een technische opleidingsachtergrond. Dit hoofdstuk zal een beeld geven van het aantal schoolverlaters met een technische opleiding dat de komende jaren op de arbeidsmarkt komt.

Dit hoofdstuk is verder als volgt ingedeeld. In paragraaf 4.2 zal eerst worden ingegaan op de historische en toekomstige ontwikkelingen in het aantal gediplomeerden met een technische opleidingsachtergrond. Daarbij zal bovendien een relatie worden gelegd met het totaal aantal gediplomeerden. Vervolgens worden in paragraaf 4.3 de verwachte ontwikkelingen in de instroom van technisch opgeleide schoolverlaters belicht.

\subsection{Historische en toekomstige ontwikkeling in het aantal gediplomeerden}

De ontgroening van de bevolking heeft in het onderwijs een daling in het aantal leerlingen en studenten veroorzaakt en hiermee tevens een daling van het aantal gediplomeerden. Sinds 1980 is het aantal leerlingen en studenten in het voltijdonderwijs met gemiddeld $1 \%$ per jaar gedaald. Deze daling is in 1992 echter overgegaan in een lichte stijging (zie CBS, 1994). De ontwikkeling van het aantal onderwijsvolgenden loopt tussen de verschillende opleidingsniveaus nogal uiteen. Het aantal leerlingen in het VBO neemt sinds 1980 gestaag af. Daarentegen groeit binnen het MBO, HBO en WO vanaf 1980 het aantal onderwijsvolgenden. De groei heeft zich het sterkst op MBO-niveau gemanifesteerd. De laatste jaren is de gemiddelde stijging of daling van het aantal leerlingen en studenten op de verschillende onderwijsniveaus echter afgezwakt. Een uitzondering daarbij is het $\mathrm{HBO}$, dat een groei doormaakt die groter is dan de gemiddelde groei sinds 1980. Binnen de opleidingsniveaus kan de ontwikkeling voor de opleidingsrichtingen verschillend zijn.

Figuur 4.1 geeft aan hoe het aantal gediplomeerden met een technische opleiding ${ }^{11}$ zich ten opzichte van het totaal aantal gediplomeerden op het desbetreffende opleidingsniveau in de periode 1983-1992 heeft ontwikkeld. Tevens zijn in deze figuur de prognoses weergegeven van het aandeel technisch opgeleiden in het aantal gediplomeerden voor de periode 1992-2000. Het aandeel technisch opgeleiden is binnen het VBO het grootst. Van de gediplomeerden op VBO-niveau heeft maar liefst ongeveer $50 \%$ een opleiding in de technische richting gevolgd. In de periode 1983-1992 neemt het aandeel van technisch gediplomeerden op VBO-niveau eerst licht toe tot circa $52 \%$ in 1985 , om vervolgens af te nemen tot iets minder dan $48 \%$ in 1988. Sindsdien is er weer een lichte stijging waar te nemen. Het aantal gediplomeerden van het VBO technisch is van ruim 52.000 in 1984 afgenomen tot ruim 31.000 in 1991. Dit beeld komt overeen met de algemene daling van het aantal VBO-leerlingen die sinds 1980 waarneembaar is. Verwacht wordt dat de daling van het aantal gediplomeerden van het VBO technisch zich de komende jaren zal voortzetten tot circa 26.000 in 1999 . De lichte opleving van de technische

11. Opgemerkt moet worden dat gediplomeerden kunnen gaan doorleren en dus niet noodzakelijkerwijs schoolverlaters hoeven te zijn. Vooral bij de opleidingen op VBO-niveau is dit het geval. Daarnaast verschilt de in deze figuur gehanteerde definitie van het technisch onderwijs iets met de elders in dit rapport gehanteerde definities van de technische opleidingen. Op het gepresenteerde totaalbeeld zal dit echter niet of nauwelijks effect hebben. 
richtingen in vergelijking met de andere opleidingen op VBO-niveau die zich sinds 1988 heeft voorgedaan, zal wederom omslaan in een geleidelijke afname. Vanaf 1993 wordt een daling van het aandeel gediplomeerden met een technische opleiding in het totaal aantal gediplomeerden op VBO-niveau van $50 \%$ tot iets minder dan $48 \%$ in 1999 verwacht. Dit betekent dat het aantal technisch opgeleide VBO'ers sterker afneemt dan de niet-technisch opgeleide VBO'ers.

Figuur 4.1 .

Ontwikkeling aandeel technisch gediplomeerden in het totaal aantal gediplomeerden per opleidingsniveau 1983-2000

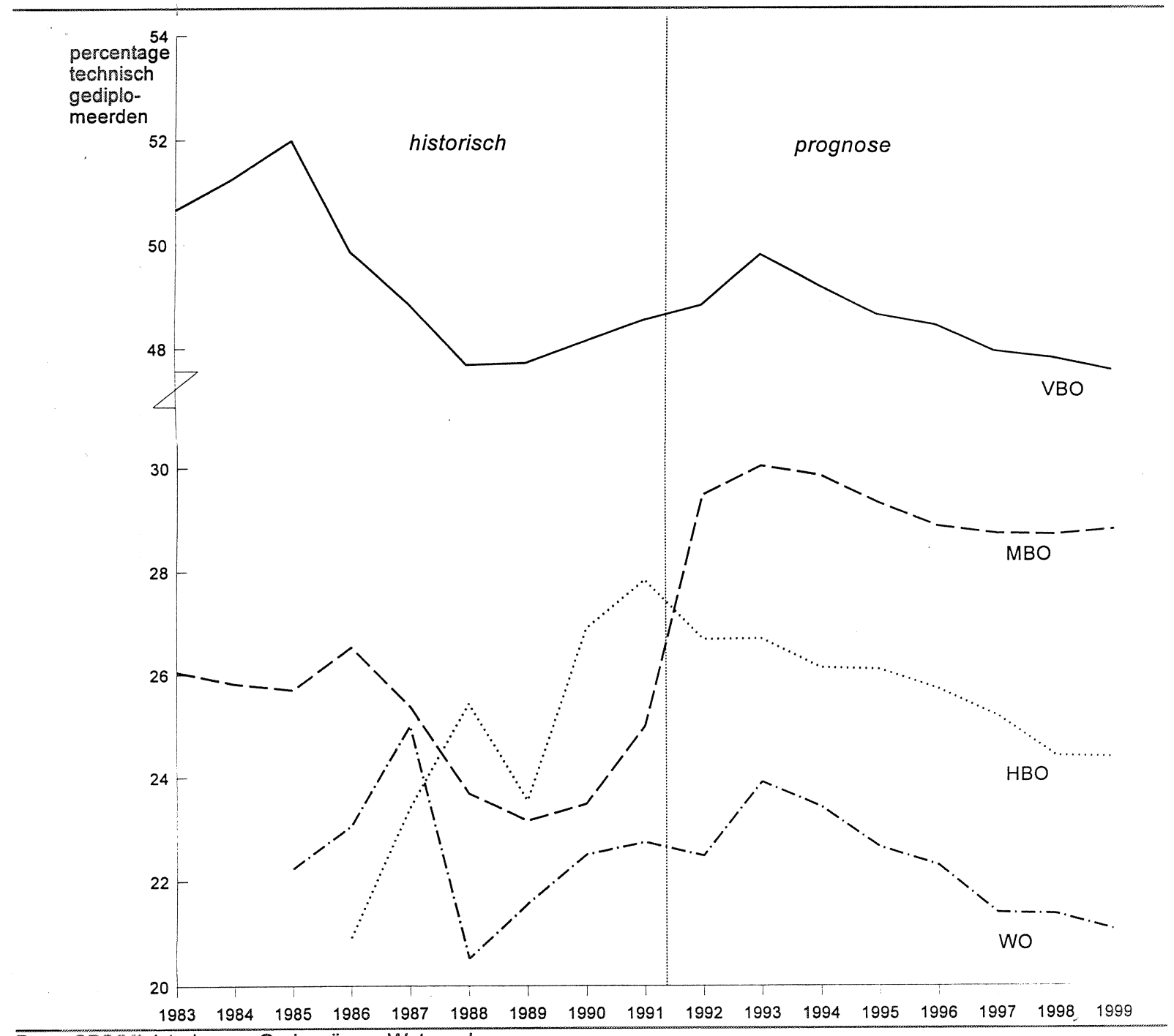

Bron: CBS/Ministerie van Onderwijs en Wetenschappen

Binnen het MBO neemt het aandeel gediplomeerden met een technische opleidingsachtergrond in de periode $1983-1989$ af van $26 \%$ tot ongeveer $23 \%$. Vanaf 1989 neemt het aandeel daarentegen weer toe tot $25 \%$ in 1991. Verwacht wordt dat deze stijging zich zal voortzetten en gedurende de jaren ' 90 rond de $29 \%$ schommelt. Het aantal leerlingen in het MBO is echter sinds 1980 , zoals al eerder is opgemerkt, sterk toegenomen. Dit betekent dat het aantal gediplomeerden van de technische opleidingen op MBO-niveau gedurende de afgelopen jaren flink gestegen is: van ruim 11.000 in 1983 tot bijna 14.000 in 1991. Ook in de periode tot het jaar 2000 blijt het aantal gediplomeerden ongeveer op dit niveau liggen. 
In het algemeen kan worden gesteld dat in de periode 1986 tot 1992 het aandeel gediplomeerden met een technische HBO-opleiding in het totaal aantal gediplomeerden op HBO-niveau sterk is gestegen. In 1986 heeft iets meer dan $20 \%$ van de gediplomeerden HBO'ers een technische opleiding gevolgd, in 1991 is dit percentage toegenomen tot ongeveer $28 \%$. Hiermee is de stijging van het aandeel technisch opgeleiden in de afgelopen jaren het grootst van alle opleidingsniveaus. In de komende jaren zal het aandeel technisch opgeleiden in het totaal aantal gediplomeerden van het HBO naar verwachting echter weer licht afnemen. Het aandeel daalt tot ruim $24 \%$ in 1999. Dit betekent dat de technische opleidingen binnen het HBO relatief minder profiteren van de verwachte forse toename in het aantal HBO-gediplomeerden de komende jaren. Overigens neemt het aantal gediplomeerden van het HBO technisch de komende jaren nog wel toe. $\mathrm{Er}$ is hier sprake van een jaarlijkse groei van het aantal gediplomeerden van ongeveer $3 \%$.

Binnen het WO neemt in de periode 1985-1992 het aandeel van de technisch opgeleiden in het totaal aantal afgestudeerden op WO-niveau eerst toe, maakt een enorme terugval in 1988 en stijgt vervolgens weer licht. Deze schokkende beweging heeft ongetwijfeld te maken met de invoering van de 'tweefasenstructuur' in het wetenschappelijk onderwijs in 1982. De eerste 'nieuwe stijl'-afgestudeerden hebben in 1986 hun studie afgerond. Ook de laatste 'oude stijlers' konden in dat jaar hun studie hebben afgerond, zodat er in feite een 'dubbele' arbeidsmarktinstroom is geweest. Ook in 1987 en 1988 was dat effect nog merkbaar. Blijkbaar heeft deze wijziging in het stelsel van hoger onderwijs voor de spreiding van de uitstroom van technisch opgeleiden een iets ander effect gehad dan voor de andere opleidingen. Voor de prognoseperiode wordt verwacht dat het aandeel afgestudeerden met een technische opleiding in het totaal aantal afgestudeerden op WO-niveau tot en met het jaar 1993 nog toeneemt, om vervolgens af te nemen tot circa $21 \%$ in het jaar 1999. Daarbij neemt naar verwachting ook het aantal afgestudeerden van het WO technisch licht af, een daling die zich vooral in de tweede helft van de jaren '90 zal voordoen.

Er zijn geen prognoses beschikbaar van het aantal gediplomeerden, verbijzonderd naar de in dit rapport onderscheiden technische opleidingen. Voor de historische periode zijn er daarentegen geen gedetailleerde cijfers beschikbaar van het aantal schoolverlaters ${ }^{12}$ dat zich aanbiedt op de arbeidsmarkt. Om toch een indicatie te kunnen geven van hoe het beeld tussen de onderscheiden richtingen verandert, wordt in tabel 4.1 per opleidingsniveau het percentage gediplomeerden in de onderscheiden richtingen in de periode 1986-1992 vergeleken met het percentage gediplomeerde schoolverlaters in de desbetreffende richting in de periode 1993-2000. Daarbij moet wel worden bedacht dat zeker voor de opleidingen op VBO- en MBO-niveau het verschil tussen beide perioden een vertekend beeld oplevert, gezien het genoemde verschil in definitie tussen schoolverlaters en gediplomeerden.

In het algemeen komt de verdeling over de opleidingsrichtingen van de gediplomeerden en schoolverlaters voor de beide onderscheiden perioden redelijk goed met elkaar overeen. Bovendien spoort dit beeld vrij goed met de verdeling bij de werkenden (zie tabel 2.1). Toch zijn er wat dit laatste betreft enkele opmerkelijke verschillen. Zo heeft momenteel circa $20 \%$ van alle werkenden met een bèta/technische opleiding op WO-niveau een studie in de bouwkunde/civiele techniek afgerond. Het aantal recent afgestudeerden in deze richting, alsmede de verwachtingen voor de komende jaren geeft een veel lager percentage voor deze richting te zien. Vooral de richting werktuigbouwkunde en voor de prognoseperiode ook de richting elektrotechniek/informatica zijn populairder geworden. Eenzelfde beeld wordt

12. Het verschil tussen gediplomeerden en schoolverlaters is als volgt: onder gediplomeerden worden degenen verstaan die met diploma hun opleiding afronden, ongeacht of ze zich aanbieden op de arbeidsmarkt of verder gaan leren. Onder schoolverlaters worden alleen diegenen verstaan die geen voltijd-vervolgopleiding meer gaan volgen. 
geconstateerd voor de opleidingen op HBO-niveau. Ook hier mogen de opleidingen werktuigbouwkunde en vooral elektrotechniek/informatica zich in een grotere belangstelling verheugen.

Tabel 4.1

Ontwikkeling aandeel gediplomeerden van de opleidingsrichtingen binnen een opleidingsniveau gemiddelde 1985-1992 en verwachte ontwikkeling gediplomeerde schoolverlaters gemiddelde 1993-2000

\begin{tabular}{lc}
\hline Opleidingsniveau en -richting & $\begin{array}{c}1985-1992^{*} \\
\%\end{array}$ \\
$\%$
\end{tabular}

Wetenschappelijk onderwijs

Wiskunde en natuurwetenschappen

Technisch

bouwkunde/civiele techniek

werktuigbouwkunde

13,2

12,1

9,9

8,8

elektrotechniek/informatica

Hoger beroepsonderwijs

Technisch laboratorium

Technisch

bouwkunde/weg- en waterbouwkunde

werktuigbouwkunde

Middelbaar beroepsonderwijs

Technisch laboratorium

Technisch

bouwkunde

weg- en waterbouwkunde

metaalkunde

fijnmechanische techniek

werktuigbouwkunde

motorvoertuigentechniek

elektrotechniek

procestechniek

$\begin{array}{rr}8,9 & 14,6 \\ 6,7 & 2,9 \\ 0,1 & 7,5 \\ 1,6 & 1,3 \\ 28,7 & 14,2 \\ 2,5 & 9,8 \\ 43,0 & 29,2 \\ 1,3 & 1,3\end{array}$

Voorbereidend beroepsonderwijs

\section{Technisch}

bouwtechniek

installatietechniek

metaalkunde

motorvoertuigentechniek

elektrotechniek

grafische techniek

consumptieve techniek

$\begin{array}{rr}22,1 & 23,3 \\ 3,5 & 3,4 \\ 26,6 & 25,1 \\ 11,9 & 10,1 \\ 21,0 & 19,0 \\ 2,5 & 3,0 \\ 8,8 & 8,4\end{array}$

* voor het WO en HBO 1986-1992 en voor het VBO 1984-1991

Bron: CBS/Ministerie van Onderwijs en Wetenschappen/ROA

Vanwege het feit dat veel leerlingen na hun VBO- of MBO-opleiding besluiten verder te gaan leren is het beeld voor deze beide opleidingsniveaus voor de historische en de prognoseperiode niet goed vergelijkbaar. Ook de vergelijking met de verdeling van het aantal werkenden gaat om deze reden mank. Vooral op MBO-niveau zijn echter toch enkele trends duidelijk. Evenals in het hoger onderwijs is er een relatief grotere belangstelling voor de richting werktuigbouwkunde zichtbaar. In vergelijking met de andere technische opleidingen op MBO-niveau is het aantal gediplomeerden en het verwachte aantal schoolverlaters van de richting elektrotechniek relatief hoog ten opzichte van het aantal werkenden met deze opleidingsachtergrond. 
Wanneer de verdeling van de gediplomeerden over de onderscheiden technische opleidingen in de periode 1986-1992 wordt vergeleken met de verwachte aandelen van de verschillende technische opleidingen in het totaal aantal schoolverlaters voor de jaren 1993-2000 vallen enkele opmerkelijke verschillen op. Het meest duidelijk zijn die bij de universitaire opleidingen. Bij de opleidingen in de wiskunde en natuurwetenschappen en bij de studies bouwkunde en civiele techniek is er sprake van een sterke afname van de het aandeel in het totaal aantal afstuderenden. Daarentegen is er sprake van een toenemend aandeel van de richting elektrotechniek/informatica. Het aandeel van deze opleidingsrichting op WO-niveau zal de komende periode naar verwachting vrijwel verdubbelen.

Op HBO-niveau treden er ten aanzien van de verdeling van de afgestudeerden over de richtingen de komende jaren slechts geringe veranderingen op. Wel blijkt de laboratoriumopleiding iets aan belangstelling te verliezen. Voor het MBO is het beeld tussen beide perioden vanwege het doorleren van leerlingen, zoals gezegd, niet goed vergelijkbaar. Qua rangorde blijkt de verdeling over de richtingen echter ongeveer hetzelfde. Op VBO-niveau stemt het beeld voor de prognoseperiode ongeveer overeen met de ontwikkelingen van de afgelopen jaren.

\subsection{Verwachte instroom van schoolverlaters}

Met als uitgangspunt de Referentieraming 1994 van het Ministerie van Onderwijs en Wetenschappen (1994) is de verwachte toekomstige instroom van schoolverlaters met een technische opleiding bepaald. Daarbij is in tegenstelling tot de in de vorige paragraaf gepresenteerde cijfers, tevens rekening gehouden met de ongediplomeerde instroom vanuit het voltijdonderwijs en de instroom vanuit het nietreguliere onderwijs en de verschillende vormen van beroepsgerichte volwasseneneducatie. Tabel 4.2 geeft een overzicht van de verwachte toekomstige instroom van schoolverlaters met een technische opleidingsachtergrond, verbijzonderd naar opleidingsniveau en -richting.

De verwachte instroom van schoolverlaters is relatief het grootst voor de technische opleidingen op WOniveau. De arbeidsmarktinstroom vanuit deze opleidingen bedraagt, uitgedrukt in procenten van het aantal werkenden naar verwachting gemiddeld ruim $4 \%$ per jaar. Binnen deze WO-opleidingen kent de richting werktuigbouwkunde het hoogste instroompercentage. De instroom van afgestudeerden met deze opleidingsachtergrond is naar verwachting ongeveer $6 \%$ per jaar. Dit is tevens het hoogste jaarlijkse instroompercentage van alle onderscheiden technische opleidingsrichtingen. Voor de opleiding WO bouwkunde/civiele techniek wordt een opvallend lage instroom van afgestudeerden op de arbeidsmarkt verwacht. In absolute termen gesproken stromen er naar verwachting 3.400 schoolverlaters in de periode 1993-2000 naar de arbeidsmarkt. Dit is jaarlijks gemiddeld 2,4\% van de werkgelegenheid voor deze opleiding. Dit relatief lage percentage kan voor een deel worden verklaard door de numerus fixus voor deze opleiding aan zowel de Technische Universiteit Delft als de Technische Universiteit Eindhoven. Binnen de onderscheiden technische opleidingen op WO-niveau is de instroom van schoolverlaters met een opleiding in de wiskunde en natuurwetenschappen absoluut gezien het grootst. Daarbij gaat het, in volgorde van belangrijkheid, vooral om afgestudeerden van de studies biologie, scheikunde, natuurkunde en wiskunde.

Voor de technische opleidingen op HBO-niveau is de arbeidsmarktinstroom van schoolverlaters gemiddeld $3,8 \%$ per jaar. Daarbij is zowel het gemiddeld jaarlijks instroompercentage als het absolute aantal schoolverlaters voor de richting elektrotechniek/informatica het grootst. Er stromen naar verwachting tot het jaar 2000 ongeveer 15.000 schoolverlaters elektrotechniek/informatica de arbeidsmarkt op. Dit komt overeen met ongeveer $5 \%$ gemiddeld per jaar. De verwachte arbeidsmarktinstroom van schoolverlaters met een HBO-opleiding werktuigbouwkunde is in de prognoseperiode ongeveer 11.000 , 
ofwel 4,6\% gemiddeld per jaar. Op HBO-niveau is de verwachte instroom het laagst voor de opleiding bouwkunde/weg- en waterbouwkunde. In de periode 1993-2000 bedraagt het instroompercentage naar verwachting $2,2 \%$ per jaar.

Tabel 4.2

Verwachte instroom van technisch opgeleide schoolverlaters naar opleidingsniveau en -richting 2000 basisscenario (totaal aantal en gemiddeld jaarlijks percentage)

\begin{tabular}{|c|c|c|}
\hline Opleidingsniveau en -richting & aantal & $\%$ \\
\hline \multicolumn{3}{|l|}{ Wetenschappelijk onderwijs } \\
\hline Wiskunde en natuurwetenschappen & 8.900 & 3,1 \\
\hline $\begin{array}{l}\text { Technisch } \\
\text { bouwkunde/civiele techniek } \\
\text { werktuigbouwkunde } \\
\text { elektrotechniek/informatica }\end{array}$ & $\begin{array}{r}20.500 \\
3.400 \\
4.500 \\
5.500\end{array}$ & $\begin{array}{l}4,3 \\
2,4 \\
5,9 \\
5,5\end{array}$ \\
\hline \multicolumn{3}{|l|}{ Hoger beroepsonderwijs } \\
\hline Technisch laboratorium & 6.400 & 3,2 \\
\hline $\begin{array}{l}\text { Technisch } \\
\text { bouwkunde/weg- en waterbouwkunde } \\
\text { werktuigbouwkunde } \\
\text { elektrotechniek/informatica }\end{array}$ & $\begin{array}{r}35.700 \\
5.400 \\
10.900 \\
15.000\end{array}$ & $\begin{array}{l}3,8 \\
2,2 \\
4,6 \\
4,9\end{array}$ \\
\hline \multicolumn{3}{|l|}{ Middelbaar beroepsonderwijs } \\
\hline Technisch laboratorium & 4.100 & 4,0 \\
\hline $\begin{array}{l}\text { Technisch } \\
\text { bouwkunde } \\
\text { weg-en waterbouwkunde } \\
\text { metaalkunde } \\
\text { fijnmechanische techniek } \\
\text { werktuigbouwkunde } \\
\text { motorvoertuigentechniek } \\
\text { elektrotechniek } \\
\text { procestechniek }\end{array}$ & $\begin{array}{r}228.400 \\
43.500 \\
6.200 \\
19.100 \\
2.100 \\
26.500 \\
28.200 \\
52.200 \\
3.100\end{array}$ & $\begin{array}{l}4,1 \\
3,4 \\
3,8 \\
4,0 \\
1,9 \\
3,9 \\
5,3 \\
4,5 \\
2,2\end{array}$ \\
\hline \multicolumn{3}{|l|}{ Voorbereidend beroepsondenwijs } \\
\hline $\begin{array}{l}\text { Technisch } \\
\text { bouwtechniek } \\
\text { installatietechniek } \\
\text { metaalkunde } \\
\text { motorvoertuigentechniek } \\
\text { elektrotechniek } \\
\text { grafische techniek } \\
\text { consumptieve techniek }\end{array}$ & $\begin{array}{r}54.800 \\
12.300 \\
1.600 \\
16.900 \\
4.500 \\
8.200 \\
1.300 \\
4.000\end{array}$ & $\begin{array}{l}1,5 \\
1,2 \\
1,7 \\
1,6 \\
1,4 \\
1,8 \\
2,3 \\
2,3\end{array}$ \\
\hline
\end{tabular}

Bron: ROA

In absolute termen is de instroom van schoolverlaters met een technische opleiding op MBO-niveau het grootst. Naar verwachting zullen er tot 2000 ruim 225.000 schoolverlaters de arbeidsmarkt met een dergelijke opleiding betreden. Van de totale arbeidsmarktinstroom van technici op MBO-niveau bestaat een ongeveer even groot deel uit schoolverlaters met een voltijdopleiding als uit schoolverlaters met een opleiding in het leerlingwezen. Binnen de technische MBO-opleidingen kent de richting motorvoertuigentechniek relatief de hoogste verwachte instroom van schoolverlaters. De instroom is voor deze opleiding naar verwachting ruim 5\% gemiddeld per jaar. Daarvan hebben er veel een opleiding in het leerlingwezen gevolgd. De opleidingen fijnmechanische techniek, procestechniek en bouwkunde hebben naar verwachting verhoudingsgewijs de laagste toekomstige instroom van schoolverlaters. Vooral voor 
de laatstgenoemde opleiding is dit opvallend, daar het hier gaat om de grootste groep werkenden met een technische achtergrond of MBO-niveau. Van de schoolverlaters met een opleiding bouwkunde op MBO-niveau zal overigens een relatief groot deel een opleiding in het leerlingwezen hebben gevolgd. In absolute aantallen gezien is de instroom van schoolverlaters op de arbeidsmarkt het grootst voor de richting elektrotechniek. Naar verwachting zullen maar liefst ruim 52.000 schoolverlaters met deze opleidingsachtergrond de arbeidsmarkt betreden. De toekomstige schoolverlaters elektrotechniek zullen naar verwachting relatief vaak een voltijdopleiding hebben afgerond. Elektrotechniek wordt binnen het leerlingwezen relatief weinig gevolgd. Binnen het voltijdonderwijs zullen de meeste leerlingen de lange MBO-opleiding elektrotechniek volgen, maar tevens volgt een belangrijk deel een opleiding binnen het kort MBO.

Op VBO-niveau is de verwachte instroom van technisch opgeleide schoolverlaters in vergelijkjing met de andere opleidingsniveaus relatief erg klein. Voor de prognoseperiode wordt verwacht dat de instroom van schoolverlaters naar de arbeidsmarkt slechts $1,5 \%$ gemiddeld per jaar is. Van de reeds werkzame beroepsbevolking heeft echter een groot deel een technische opleiding op VBO-niveau afgerond. Dit duidt op een opmerkelijke toename van het opleidingsniveau van de technisch opgeleide beroepsbevolking. Veel schoolverlaters met een reguliere opleiding op VBO-niveau zullen doorstromen naar het leerlingwezen, zodat ze uiteindelijk een hogere (MBO) opleidingskwalificatie verwerven. Deze stijging van het opleidingsniveau wordt overigens voor een belangrijk deel door de overheid gestimuleerd door het 'startkwalificatie'-niveau op de arbeidsmarkt op het niveau van primair leerlingwezen te leggen.

Binnen de technische opleidingen op VBO-niveau kent de richting bouwtechniek met een instroompercentage van jaarlijks gemiddeld $1,2 \%$ relatief de kleinste arbeidsmarktinstroom. Voor de opleidingen grafische en consumptieve techniek is de instroom van schoolverlaters naar verwachting relatief het grootst. Het instroompercentage is voor beide richtingen jaarlijks gemiddeld $2,3 \%$ van het aantal werkenden. In absolute termen stromen de meeste schoolverlaters met een opleiding VBO metaalkunde naar de arbeidsmarkt. Overigens heeft ook het grootste deel van de reeds werkzame beroepsbevolking met een technische VBO-opleiding een metaalkunde-opleiding gevolgd. De verwachte arbeidsmarktinstroom van deze schoolverlaters is naar verwachting bijna 17.000 , hetgeen overeenkomt met $1,6 \%$ gemiddeld per jaar. 


\section{De confrontatie van vraag en aanbod}

\subsection{Inleiding}

In dit hoofdstuk wordt de verwachte vraag naar nieuwkomers op de arbeidsmarkt geconfronteerd met het verwachte aanbod. De verwachte vraag is de som van de verwachte (positieve) uitbreidingsvraag en de verwachte vervangingsvraag gedurende de periode 1993-2000. Het verwachte aanbod per opleiding bestaat uit de instroom van schoolverlaters op de arbeidsmarkt in deze periode en het aantal kortdurige werklozen met de desbetreffende opleiding aan het begin van die periode.

De confrontatie van vraag en aanbod vindt in dit hoofdstuk op twee manieren plaats. Eerst wordt in kwantitatieve zin een vraag-aanbod-confrontatie opgesteld. Daarbij wordt niet, zoals nogal eens wordt gedaan, eenvoudigweg het verschil tussen vraag en aanbod weergegeven, maar wordt de 'kloof tot het evenwicht' gepresenteerd. Hierdoor wordt beter rekening gehouden met de veranderingen in vraag en aanbod die het gevolg zijn van de aanvankelijk te verwachten spanningen op de arbeidsmarkt.

Een dergelijke aanpak houdt echter te weinig rekening met de interactie tussen vraag- en aanbodverhoudingen tussen de verschillende opleidingen. Om de arbeidsmarktperspectieven voor schoolverlaters of de te verwachten knelpunten die werkgevers ondervinden bij de personeelsvoorziening in kaart te brengen moet met deze mogelijke substitutie wel rekening worden gehouden. Daarom is in het kader van het ROA-informatiesysteem onderwijs-arbeidsmarkt de indicator toekomstige arbeidsmarktsituatie ontwikkeld, waarin de substitutie tussen verschillende opleidingscategorieën expliciet is geïncorporeerd (zie ook Matheeuwsen, Smits, Willems en Hoevenberg, 1994 en ROA, 1993).

In paragraaf 5.2 zal worden ingegaan op de te verwachten overschotten of tekorten per opleiding. Vervolgens zal paragraaf 5.3 een beeld geven van de verwachte arbeidsmarktperspectieven voor schoolverlaters alsmede van de knelpunten die werkgevers bij de personeelsvoorziening mogen verwachten. Ten slotte zal in paragraaf 5.4 worden bekeken welke bedrijfssectoren waarschijnlijk de meeste hinder zullen ondervinden van de verwachte tekorten.

\subsection{Aanbodoverschotten en -tekorten op de arbeidsmarkt}

De kwantitatieve confrontatie van vraag en aanbod geeft, zoals gezegd, een eerste beeld van de mogelijke overschotten en tekorten die op de arbeidsmarkt kunnen ontstaan. Deze kunnen worden aangeduid als de ex ante overschotten en tekorten. Ze geven een eerste indicatie van de te verwachten spanningen op de arbeidsmarkt. Zowel de vragers als aanbieders op de arbeidsmarkt zullen echter op deze spanningen reageren, vooral als de arbeidsmarktsituatie voor de verschillende opleidingen uiteenloopt. Bij een ex ante aanbodtekort van arbeidskrachten met een bepaalde opleiding zullen banen aantrekkelijker voor werknemers worden gemaakt door middel van bijvoorbeeld hogere beloningen, betere arbeidsomstandigheden, betere secundaire arbeidsvoorwaarden enz., waardoor meer leerlingen voor deze opleiding kiezen. Ook bestaat er mogelijk een grotere belangstelling voor omscholing in deze richting. Dit betekent echter tevens dat arbeidskrachten met deze opleiding duurder worden voor de werkgevers, zodat de vraag voor de desbetreffende opleiding zal gaan dalen. Uiteindelijk kan er dan een evenwicht ontstaan. Interessant is de vraag in hoeverre het ex ante aanbod per opleiding afwijkt van het aanbod in de uiteindelijke evenwichtssituatie, dat wil zeggen in welke mate het aanbod zich zou moeten aanpassen om deze evenwichtssituatie te bereiken. Dit verschil tussen het ex ante aanbod en het aanbod in de evenwichtssituatie zal verder worden getypeerd als aanbodoverschot of -tekort. 
Omdat niet geheel duidelijk is in welke mate vragers en aanbieders van arbeid op ex ante spanningen op de arbeidsmarkt zullen reageren en vanwege de onzekerheid waarmee prognoses altijd gepaard gaan, worden de verwachte overschotten en -tekorten niet als exacte prognose gepresenteerd. Tabel 5.1 geeft de intervallen waartussen de aanbodoverschotten en tekorten waarschijnlijk zullen liggen. De cijfers zijn daarbij tevens uitgedrukt in procenten van de instroom van schoolverlaters in de periode 1993-2000. Dit kan bij een aanbodtekort worden geïnterpreteerd als de extra arbeidsmarktinstroom die in deze periode nodig zou zijn om een evenwichtige arbeidsmarkt te krijgen.

Tabel 5.1

Aanbodoverschot of -tekort op de arbeidsmarkt voor technisch opgeleiden in het jaar 2000 , verbijzonderd naar opleidingsniveau en -richting basisscenario

\begin{tabular}{|c|c|c|c|c|}
\hline \multirow[t]{2}{*}{ Opleidingsniveau en -richting } & \multicolumn{2}{|c|}{$\begin{array}{c}\text { aanbodoverschot/ } \\
\text {-tekort }\end{array}$} & \multicolumn{2}{|c|}{$\begin{array}{l}\text { in procenten van instroom } \\
\text { van schoolverlaters }\end{array}$} \\
\hline & minimum & maximum & minimum & maximum \\
\hline Wiskunde en natuurwetenschappen & -500 & -1.100 & -6 & -12 \\
\hline $\begin{array}{l}\text { Technisch } \\
\text { bouwkunde/civiele techniek } \\
\text { werktuigbouwkunde } \\
\text { elektrotechniek/informatica }\end{array}$ & $\begin{array}{r}-1.700 \\
-1.400 \\
0 \\
0\end{array}$ & $\begin{array}{r}-3.500 \\
-2.800 \\
0 \\
0\end{array}$ & $\begin{array}{r}-9 \\
-42 \\
0 \\
0\end{array}$ & $\begin{array}{r}-17 \\
-84 \\
0 \\
0\end{array}$ \\
\hline \multicolumn{5}{|l|}{ Hoger beroepsonderwijs } \\
\hline Technisch laboratorium & -300 & -600 & -4 & -9 \\
\hline $\begin{array}{l}\text { Technisch } \\
\text { bouwkunde/weg- en waterbouwkunde } \\
\text { werktuigbouwkunde } \\
\text { elektrotechniek/informatica }\end{array}$ & $\begin{array}{r}-1.600 \\
-1.600 \\
100 \\
600\end{array}$ & $\begin{array}{r}-3.200 \\
-3.300 \\
100 \\
1.200\end{array}$ & $\begin{array}{r}-4 \\
-31 \\
1 \\
4\end{array}$ & $\begin{array}{r}-9 \\
-61 \\
1 \\
8\end{array}$ \\
\hline \multicolumn{5}{|l|}{ Middelbaar beroepsonderwijs } \\
\hline Technisch laboratorium & 400 & 700 & 8 & 17 \\
\hline $\begin{array}{l}\text { Technisch } \\
\text { bouwkunde } \\
\text { weg- en waterbouwkunde } \\
\text { metaalkunde } \\
\text { fijnmechanische techniek } \\
\text { werktuigbouwkunde } \\
\text { motorvoertuigentechniek } \\
\text { elektrotechniek } \\
\text { procestechniek }\end{array}$ & $\begin{array}{r}14.600 \\
400 \\
600 \\
800 \\
-300 \\
1.900 \\
3.000 \\
5.700 \\
100\end{array}$ & $\begin{array}{r}29.300 \\
900 \\
1.200 \\
1.700 \\
-600 \\
3.800 \\
5.900 \\
11.400 \\
100\end{array}$ & $\begin{array}{r}6 \\
1 \\
10 \\
4 \\
-13 \\
7 \\
11 \\
11 \\
2\end{array}$ & $\begin{array}{r}13 \\
2 \\
20 \\
9 \\
-27 \\
14 \\
21 \\
22 \\
4\end{array}$ \\
\hline \multicolumn{5}{|l|}{ Voorbereidend beroepsonderwijs } \\
\hline $\begin{array}{l}\text { Technisch } \\
\text { bouwtechniek } \\
\text { installatietechniek } \\
\text { metaalkunde } \\
\text { motorvoertuigentechniek } \\
\text { elektrotechniek } \\
\text { grafische techniek } \\
\text { consumptieve techniek }\end{array}$ & $\begin{array}{r}-3.800 \\
-900 \\
100 \\
-800 \\
-100 \\
400 \\
0 \\
400\end{array}$ & $\begin{array}{r}-7.500 \\
-1.800 \\
300 \\
-1.700 \\
-100 \\
900 \\
0 \\
800\end{array}$ & $\begin{array}{r}-7 \\
-7 \\
8 \\
-5 \\
-1 \\
5 \\
1 \\
10\end{array}$ & $\begin{array}{r}-14 \\
-15 \\
16 \\
-10 \\
-3 \\
11 \\
1 \\
19\end{array}$ \\
\hline
\end{tabular}

Bron: ROA 
Er wordt een relatief groot tekort verwacht aan technisch opgeleiden op WO-niveau. Het blijkt echter dat dit voornamelijk een tekort aan afgestudeerden met een opleiding bouwkunde/civiele techniek betreft. De instroom van schoolverlaters uit deze opleiding is klein in vergelijking met de andere technische opleidingen op WO-niveau, terwijl de verwachte totale vraag naar deze opleiding relatief groot is. Het aanbodtekort zal naar verwachting maar liefst tussen de $42 \%$ en $84 \%$ van de instroom liggen. Dit betekent dat er de komende jaren zo'n 1.500 tot 3.000 afgestudeerden te weinig van de opleiding op de markt komen. Zoals reeds in het vorige hoofdstuk is opgemerkt, bestaat er momenteel een numerus fixus voor de bouwkunde-opleidingen in zowel Delft als Eindhoven.

De totale vraag naar nieuwkomers met een opleiding werktuigbouwkunde of elektrotechniek/informatica is eveneens vrij groot, maar hier staat tegenover dat de instroom in verhouding ook groot is, zodat de arbeidsmarkt voor deze richtingen min of meer in evenwicht is. Naar verwachting zal het aanbodtekort van schoolverlaters met een opleiding wiskunde of natuurwetenschappen tussen de $6 \%$ en $12 \%$ liggen. Ook bij deze opleiding wordt dit vooral veroorzaakt door een achterblijvende instroom van schoolverlaters op de arbeidsmarkt.

Het verwachte tekort aan nieuwkomers met een technische opleiding op HBO-niveau is in verhouding minder groot dan van werkenden met een opleiding op WO-niveau. Dit aanbodtekort is bijna geheel toe te schrijven aan het verwachte tekort aan nieuwkomers met een opleiding bouwkunde/weg- en waterbouwkunde. Het verwachte aanbodtekort bedraagt zo'n $30 \%$ tot $60 \%$ van de totale arbeidsmarktinstroom van nieuwkomers tot het jaar 2000. De verwachte instroom voor deze opleiding is in verhouding veel lager dan voor de andere richtingen op HBO-niveau. Bij zowel de opleiding HBO werktuigbouwkunde als de opleiding HBO elektrotechniek/informatica worden kleine aanbodoverschotten verwacht. Bij HBO werktuigbouwkunde is dit vooral toe te schrijven aan de in verhouding vrij hoge instroom van schoolverlaters op de arbeidsmarkt, terwijl bij HBO elektrotechniek/informatica de verwachte vraag naar nieuwkomers wat achterblijft, als gevolg van een vrij lage vervangingsvraag. $\mathrm{Er}$ zullen naar verwachting wel kleine aanbodtekorten van schoolverlaters met een opleiding HBO technisch laboratorium optreden, omdat de instroom op de arbeidsmarkt vanuit deze opleiding relatief laag is.

Er wordt een aanbodoverschot verwacht van technisch opgeleiden op MBO-niveau. Het totale aanbodoverschot bij MBO technisch zal naar verwachting tussen de $6 \%$ en $13 \%$ van de totale arbeidsmarktinstroom liggen. Dit komt overeen met een overschot van 15.000 tot 30.000 arbeidskrachten. De opleiding fijnmechanische techniek vormt echter een uitzondering. Naar verwachting zal er een relatief gezien groot tekort aan nieuwkomers met deze opleiding ontstaan. In aantallen komt dit neer op een tekort van tussen de 300 en 600 arbeidskrachten. De arbeidsmarktinstroom vanuit deze opleiding is relatief klein, terwijl de totale vraag relatief groot is, vooral als gevolg van een grote vervangingsvraag. De relatief grootste aanbodoverschotten zijn te vinden bij de opleidingen MBO elektrotechniek, MBO motorvoertuigentechniek en MBO weg- en waterbouwkunde. Voor de opleidingen elektrotechniek en motorvoertuigentechniek geldt vooral dat de instroom relatief groot is, terwijl bij de richting weg- en waterbouwkunde de vraag naar nieuwkomers wat achterblijft, met name omdat de vervangingsvraag voor deze richting in verhouding nogal laag is. Voor de richtingen bouwkunde en procestechniek zal de arbeidsmarktsituatie naar verwachting niet ver van het evenwicht verwijderd zijn. Het aanbodoverschot van mensen met een technische laboratoriumopleiding op MBO-niveau zal daarentegen tussen de $8 \%$ en $17 \%$ van de instroom bedragen.

Opvallend genoeg zal volgens deze basisprognose naar verwachting een tekort aan technisch opgeleiden op VBO-niveau optreden. Ook al is de totale vraag naar nieuwkomers met een technische 
opleiding op VBO-niveau relatief laag, de verwachte instroom van schoolverlaters met deze opleidingen is toch nog te klein om aan deze vraag te kunnen voldoen. Dit heeft vooral te maken met de sterk toegenomen doorstroom van VBO'ers naar opleidingen op MBO-niveau. Het relatief grootste aanbodtekort zal zich naar verwachting voordoen bij de opleiding VBO bouwtechniek. De instroom op de arbeidsmarkt vanuit deze opleiding is relatief gezien naar verwachting zeer laag. Bij de richting metaalkunde zal het verwachte aanbodtekort tussen de $5 \%$ en $10 \%$ van de totale instroom van schoolverlaters liggen. Voor de opleidingen grafische techniek en motorvoertuigentechniek wordt een redelijk evenwichtige marktsituatie verwacht. Ten slotte zal er een relatief groot aanbodoverschot van nieuwkomers met de opleidingen installatietechniek en consumptieve techniek ontstaan.

\subsection{Toekomstige arbeidsmarktsituatie}

Tot nu toe is geen rekening gehouden met de interactie tussen de vraag- en aanbodverhoudingen van de verschillende opleidingen. Een aanbodtekort bij een bepaalde opleiding kan er echter toe leiden dat werkgevers arbeidskrachten met een andere opleiding gaan aannemen. Hierdoor veranderen de vraagen aanbodverhoudingen van deze laatste opleiding weer. Als er bijvoorbeeld een overschot is aan technisch opgeleiden op MBO-niveau dan zullen MBO'ers op den duur aantrekkelijker worden voor werkgevers. Zij zullen dan vaker MBO'ers gaan aannemen in plaats van VBO'ers. VBO'ers worden dan in feite van de arbeidsmarkt verdrongen door MBO'ers. De vraag naar VBO'ers daalt derhalve als gevolg van een aanbodoverschot van MBO'ers. Dit betekent dat de arbeidsmarktperspectieven voor de schoolverlaters van het VBO slechter worden. De perspectieven voor MBO'ers worden hierdoor echter niet beter. Zij hebben weliswaar een grotere kans op een baan, maar deze is wel vaker op een lager niveau dan men zou mogen verwachten. Door deze processen van substitutie en verdringing kan de toekomstige arbeidsmarktsituatie er derhalve heel anders uit komen te zien dan volgens de in de vorige paragraaf gepresenteerde aanbodoverschotten en -tekorten.

In de indicator toekomstige arbeidsmarktsituatie wordt expliciet rekening gehouden met de te verwachten substitutieprocessen op de arbeidsmarkt. Deze indicator geeft daarmee een veel betere indicatie van het arbeidsmarktperspectief voor schoolverlaters met een bepaalde opleiding. Daarnaast geeft de indicator een goed beeld van de knelpunten die werkgevers bij de personeelsvoorziening mogen verwachten. Als een bepaalde opleiding goede arbeidsmarktperspectieven heeft dan zal het voor schoolverlaters met deze opleiding relatief makkelijk zijn om een (passende) baan te vinden. Daarentegen zal het voor werkgevers juist moeilijk worden om schoolverlaters met deze opleiding te recruteren. $\mathrm{Er}$ is in dat geval derhalve een grote kans dat er knelpunten bij de personeelsvoorziening zullen ontstaan. Tabel 5.2 geeft een overzicht van de indicator toekomstige arbeidsmarktsituatie, verbijzonderd naar opleidingsniveau en -richting.

Alle technische opleidingen op WO-niveau, alsmede de studies in de wiskunde en natuurwetenschappen hebben een goed arbeidsmarktperspectief. Dat betekent eveneens dat de kans groot is dat er knelpunten bij de personeelsvoorziening van arbeidskrachten met deze opleidingen zullen ontstaan. De grootste kans op knelpunten doet zich voor bij de opleiding bouwkunde/civiele techniek. Zoals reeds eerder is opgemerkt, is de verwachte arbeidsmarktinstroom van schoolverlaters vanuit deze opleiding, mede gezien de numerus fixus, relatief klein. Opvallend is echter dat ook de studies werktuigbouwkunde en elektrotechniek/informatica 'profiteren' van de voor bouwkundigen en civiel technisch ingenieurs gunstige perspectieven op de arbeidsmarkt.

Voor de opleiding HBO technisch laboratorium en de opleidingen HBO bouwkunde/weg- en waterbouwkunde en HBO werktuigbouwkunde wordt eveneens een goed arbeidsmarktperspectief verwacht. 
De opleiding elektrotechniek/informatica heeft een redelijk arbeidsmarktperspectief. De kans dat er bij al deze opleidingen in de toekomst knelpunten bij de personeelsvoorziening zullen optreden is dan ook redelijk groot.

Tabel 5.2

Verwacht arbeidsmarktperspectief c.q. verwachte kans op knelpunten bij de personeelsvoorziening voor technische opleidingen naar opleidingsniveau en -richting 1993-2000 basisscenario

\begin{tabular}{|c|c|c|c|}
\hline Opleidingsniveau en -richting & $\begin{array}{l}\text { indicator toekomstige } \\
\text { arbeidsmarktsituatie }\end{array}$ & $\begin{array}{l}\text { arbeidsmarkt- } \\
\text { perspectief }\end{array}$ & $\begin{array}{l}\text { kans op knelpunten bij } \\
\text { personeelsvoorziening }\end{array}$ \\
\hline \multicolumn{4}{|l|}{ Wetenschappelijk onderwijs } \\
\hline Wiskunde en natuurwetenschappen & 0,86 & goed & groot \\
\hline $\begin{array}{l}\text { Technisch } \\
\text { bouwkunde/civiele techniek } \\
\text { werktuigbouwkunde } \\
\text { elektrotechniek/informatica }\end{array}$ & $\begin{array}{l}0,85 \\
0,72 \\
0,95 \\
0,95\end{array}$ & $\begin{array}{l}\text { goed } \\
\text { goed } \\
\text { goed } \\
\text { goed }\end{array}$ & $\begin{array}{l}\text { groot } \\
\text { groot } \\
\text { groot } \\
\text { groot }\end{array}$ \\
\hline \multicolumn{4}{|l|}{ Hoger beroepsonderwijs } \\
\hline Technisch laboratorium & 0,89 & goed & groot \\
\hline $\begin{array}{l}\text { Technisch } \\
\text { bouwkunde/weg- en waterbouwkunde } \\
\text { werktuigbouwkunde } \\
\text { elektrotechniek/informatica }\end{array}$ & $\begin{array}{l}0,92 \\
0,79 \\
0,99 \\
1,03\end{array}$ & $\begin{array}{l}\text { goed } \\
\text { goed } \\
\text { goed } \\
\text { redelijk }\end{array}$ & $\begin{array}{l}\text { groot } \\
\text { groot } \\
\text { groot } \\
\text { redelijk }\end{array}$ \\
\hline \multicolumn{4}{|l|}{ Middelbaar beroepsonderwijs } \\
\hline Technisch laboratorium & 1,07 & matig & klein \\
\hline $\begin{array}{l}\text { Technisch } \\
\text { bouwkunde } \\
\text { weg- en waterbouwkunde } \\
\text { metaalkunde } \\
\text { fijnmechanische techniek } \\
\text { werktuigbouwkunde } \\
\text { motorvoertuigentechniek } \\
\text { elektrotechniek } \\
\text { procestechniek }\end{array}$ & $\begin{array}{l}1,12 \\
1,05 \\
1,16 \\
1,12 \\
0,96 \\
1,13 \\
1,24 \\
1,19 \\
1,06\end{array}$ & $\begin{array}{l}\text { matig } \\
\text { redelijk } \\
\text { slecht } \\
\text { matig } \\
\text { goed } \\
\text { matig } \\
\text { slecht } \\
\text { slecht } \\
\text { matig }\end{array}$ & $\begin{array}{l}\text { klein } \\
\text { redelijk } \\
\text { zeer klein } \\
\text { klein } \\
\text { groot } \\
\text { klein } \\
\text { zeer klein } \\
\text { zeer klein } \\
\text { klein }\end{array}$ \\
\hline \multicolumn{4}{|l|}{ Voorbereidend beroepsonderwijs } \\
\hline $\begin{array}{l}\text { Technisch } \\
\text { bouwtechniek } \\
\text { installatietechniek } \\
\text { metaalkunde } \\
\text { motorvoertuigentechniek } \\
\text { elektrotechniek } \\
\text { grafische techniek } \\
\text { consumptieve techniek }\end{array}$ & $\begin{array}{l}1,02 \\
1,03 \\
1,14 \\
1,03 \\
1,06 \\
1,09 \\
1,05 \\
1,14\end{array}$ & $\begin{array}{l}\text { redelijk } \\
\text { redelijk } \\
\text { matig } \\
\text { redelijk } \\
\text { matig } \\
\text { matig } \\
\text { redelijk } \\
\text { matig }\end{array}$ & $\begin{array}{l}\text { redelijk } \\
\text { redelijk } \\
\text { klein } \\
\text { redelijk } \\
\text { klein } \\
\text { klein } \\
\text { redelijk } \\
\text { klein }\end{array}$ \\
\hline
\end{tabular}

Bron: ROA

De opleiding MBO technisch laboratorium heeft slechts een matig perspectief. Ook voor de meeste andere technische opleidingen op MBO-niveau is het perspectief matig. Dat komt voornamelijk door de relatief grote instroom op de arbeidsmarkt van technisch opgeleiden op MBO-niveau. Daarbij moet niet alleen worden gedacht aan de arbeidsmarktinstroom vanuit de reguliere dagopleidingen, maar ook aan de instroom vanuit het kort MBO en het leerlingwezen. De schoolverlaters van de opleidingen MBO weg- en waterbouwkunde, motorvoertuigentechniek en elektrotechniek hebben zelfs slechte perspectie- 
ven. De kans op knelpunten in de personeelsvoorziening van arbeidskrachten met deze opleidingen zijn derhalve zeer gering. De opleiding fijnmechanische techniek heeft als enige van de onderscheiden technische opleidingen op MBO-niveau een goed arbeidsmarktperspectief. Dat heeft voornamelijk te maken met de relatief grote vervangingsvraag voor deze opleiding en de lage instroom van schoolverlaters op de arbeidsmarkt. $\mathrm{Er}$ is een grote kans dat werkgevers in de komende jaren problemen gaan ondervinden bij het werven van personeel met een dergelijke opleidingsachtergrond. Voor de opleiding bouwkunde is het arbeidsmarktperspectief redelijk. De overige opleidingen op MBO-niveau hebben een matig arbeidsmarktperspectief. De kans op knelpunten in de personeelsvoorzienig is voor deze opleidingen derhalve klein.

Ondanks de in de vorige paragraaf geconstateerde aanvankelijke tekorten aan schoolverlaters bij veel technische opleidingen van VBO-niveau, is de kans op knelpunten in de personeelsvoorziening van arbeidskrachten met dergelijke opleidingen redelijk tot klein. De reden hiervoor is dat werkgevers in voldoende mate kunnen putten uit schoolverlaters van het MBO. Deze verdringing van VBO'ers door MBO'ers leidt ertoe dat de arbeidsmarktperspectieven voor bijna alle technische opleidingen op VBOniveau slechts matig zijn. Alleen voor de opleidingen bouwtechniek, metaalkunde en grafische techniek wordt een redelijk arbeidsmarktperspectief verwacht.

\subsection{Verwachte knelpunten in bedrijfssectoren}

Vooral de bedrijfssectoren die in sterke mate afhankelijk zijn van de opleidingen waarvoor een krappe arbeidsmarkt wordt verwacht, zullen waarschijnlijk problemen gaan ondervinden bij de personeelsvoorziening. Dit houdt derhalve in dat met name de bedrijfssectoren waar een grote vraag is naar hoger technisch opgeleiden naar verwachting de komende jaren moeilijkheden zullen krijgen bij de werving van nieuw personeel. Veel mensen met een technische opleiding op WO- of HBO-niveau zijn werkzaam in de metaal- en elektrotechnische industrie. Met name de HBO- en WO-opleidingen werktuigbouwkunde en elektrotechniek/informatica zijn belangrijk voor deze bedrijfssector. Momenteel werken er zo'n 10.000 HBO werktuigbouwkundigen, 12.000 HBO elektrotechnici en informatici, 3.000 WO werktuigbouwkundigen en 3.000 WO elektrotechnici en informatici in de metaalindustrie. Dit betekent dat maar liefst bijna $30 \%$ van alle arbeidskrachten met een dergelijke opleidingsachtergrond in deze sector werkzaam is. Daar komt nog bij dat in de komende jaren het belang van de hogere technische beroepen, zoals de 'hogere metaalberoepen' en de 'hogere elektrotechnische beroepen', binnen de sector metaal zal toenemen. De 'hogere elektrotechnische beroepen' zijn vooral afhankelijk van de opleidingen WO en HBO elektrotechniek/informatica. Mensen met een opleiding WO- of HBO-werktuigbouwkunde werken vaak in 'hogere metaalberoepen'. Dit duidt er op dat de vraag naar dergelijke opleidingen binnen de metaalindustrie zal gaan toenemen.

De werkgevers in de metaalsector zullen daarnaast de komende jaren moeite ondervinden bij het vinden van personeel met een opleiding VBO metaalkunde. In totaal werken er ongeveer 50.000 mensen met deze opleiding in de metaalindustrie, hetgeen betekent dat bijna $10 \%$ van de totale werkgelegenheid in de sector door arbeidskrachten met een dergelijke opleiding wordt vervuld. De kansen op knelpunten bij deze opleiding zijn redelijk groot. Hoewel de werkgelegenheid in de metaalindustrie de komende jaren naar verwachting iets zal afnemen, mag gezien de afhankelijkheid van deze sector van de opleiding VBO metaalkunde, worden verwacht dat hier de komende jaren enige recruteringsproblemen zullen optreden.

Verder zullen er problemen ontstaan in de personeelsvoorziening van arbeidskrachten met een opleiding MBO fijnmechanische techniek. Momenteel werken er ongeveer 5.000 mensen met een 
dergelijke opleidingsachtergrond in de metaalsector. Dit is ongeveer één derde van alle werkenden met deze opleiding. De problemen ontstaan vooral als gevolg van het grote personeelsverloop van arbeidskrachten met deze opleiding in de sector.

De bouwsector, die naar verwachting de komende jaren licht zal groeien, zal eveneens te kampen krijgen met een krapper wordende arbeidsmarkt. De kansen op knelpunten in de personeelsvoorziening voor de opleidingen MBO en VBO bouwkunde zijn namelijk redelijk groot. Van alle werkenden in de bouwsector heeft meer dan één derde een dergelijke opleiding gevolgd. Gezien de afhankelijkheid van de sector van arbeidskrachten met deze opleidingsachtergrond betekent dit dat er een situatie kan ontstaan waarbij de ontwikkeling van de sector als gevolg van een tekortschietend aanbod onder druk staat. Dit heeft uiteraard ook gevolgen voor de werkgelegenheid voor degenen die met een andere opleidingsachtergrond in deze sector werkzaam zijn. De, vanuit de vraagzijde gezien, kwetsbare arbeidsmarktpositie voor de bouwsector, wordt nog versterkt door het feit dat ook op HBO- en WOniveau aanzienlijke tekorten aan bouwkundigen en civiel technisch ingenieurs worden verwacht.

In de sector overige commerciële dienstverlening zijn eveneens veel arbeidskrachten met een opleiding WO bouwkunde/civiele techniek en HBO bouwkunde/weg- en waterbouwkunde werkzaam. In totaal werken ongeveer 22.000 mensen met een dergelijke opleidingsachtergrond in deze sector. Het gaat hier voornamelijk om mensen die werkzaam zijn in 'hogere bouwkundige beroepen'. Ook een aantal op de bouw gerichte (advies)bedrijven in deze sector zal derhalve waarschijnlijk problemen gaan ondervinden bij de personeelswerving voor deze beroepen.

Daarnaast werken veel mensen die een opleiding WO bouwkunde/civiele techniek of HBO bouwkunde/weg- en waterbouwkunde hebben afgerond in de sector openbaar bestuur, politie, defensie en onderwijs. Verder werken in deze sector veel wis- en natuurkundigen, vaak als docent in het voortgezet of hoger onderwijs. Ook de opleidingen WO en HBO elektrotechniek/informatica, HBO werktuigbouwkunde en HBO technisch laboratorium zijn sterk in deze sector vertegenwoordigd. Naar verwachting zal dus ook de overheidssector enige knelpunten ondervinden in de personeelsvoorziening. Tot slot zullen ook de chemische industrie en de kwartaire dienstverlening de gevolgen ondervinden van de krappe arbeidsmarkt voor de opleiding HBO technisch laboratorium. 
$\ldots \ldots$ 


\section{Enkele alternatieve scenario's}

\subsection{Inleiding}

In dit hoofdstuk wordt bekeken in hoeverre de resultaten uit hoofdstuk 3 veranderen indien de werkgelegenheid, de vervangingsvraag of de arbeidsmarktinstroom zich anders ontwikkelen dan in het basisscenario. Dit is enerzijds van belang omdat prognoses altijd met onzekerheid zijn omgeven. Anderzijds geeft dit ook een indicatie van de effectiviteit van mogelijke beleidsmaatregelen.

Voor zowel de uitbreidingsvraag, de vervangingsvraag als de arbeidsmarktinstroom is een alternatief scenario opgesteld. Allereerst wordt in paragraaf 6.2 het gunstige werkgelegenheidsscenario gepresenteerd. Vervolgens wordt in paragraaf 6.3 ingegaan op het VUTMAO-scenario, dat uitgaat van een lagere uitstroom naar de WAO en de VUT. Ten slotte komt in paragraaf 3.4 het stapelscenario voor de arbeidsmarktinstroom aan bod. In dat scenario is sprake van een grotere doorstroom van studenten van het WWO naar het WO technisch, van het MBO technisch naar het HBO technisch en van het HBO technisch naar het WO technisch.

\subsection{Het gunstige werkgelegenheidsscenario}

De resultaten van het basisscenario voor de werkgelegenheidsontwikkeling, zoals gepresenteerd in hoofdstuk 3 zijn gebaseerd op het behoedzame scenario van het CPB. In deze paragraaf worden de verwachte uitbreidingsvraagontwikkelingen voor de verschillende technische opleidingen gepresenteerd die gebaseerd zijn op het door het CPB onderscheiden gunstige scenario voor de werkgelegenheid. De veronderstellingen die aan het gunstige scenario ten grondslag liggen zijn wat optimistischer dan die van het behoedzame scenario voor de werkgelegenheid. Zo gaat dit scenario uit van een relevante groei van de wereldhandel van $6 \frac{1}{2} \%$ per jaar, hetgeen uitmondt in een economische groei van $23 / 4 \%$ per jaar. Dit zal naar verwachting leiden tot een jaarlijkse groei van het aantal werkenden met ongeveer $1,1 \%$.

Tabel 6.1

Verwachte ontwikkeling van het aantal werkenden per bedrijfstak 1993-2000 gunstig werkgelegenheidsscenario (gemiddelde jaarlijkse groei)

\begin{tabular}{lc}
\hline Bedrijfstak & $\begin{array}{c}1993-2000 \\
\%\end{array}$ \\
\hline & \\
Landbouw, visserij en bosbouw & $-0,6$ \\
Voedings- en genotmiddelenindustrie & $-0,3$ \\
Chemie & 1,3 \\
Metaal, elektrotechnische en transportmiddelenindustrie & 0,4 \\
Overige industrie (incl. kleding- en schoenenindustrie) & 0,2 \\
Energie & 0,8 \\
Bouw & 1,2 \\
Handel & 2,0 \\
Vervoer en communicatie & 0,7 \\
Overige commerciële dienstverlening & 1,9 \\
Kwartaire diensten & 2,2 \\
Openbaar bestuur, politie, defensie en onderwijs & $-0,9$ \\
Totaal & 1,1 \\
\end{tabular}

Bron: CPB/ROA 
Tabel 6.1 geeft een overzicht van de verwachte werkgelegenheidsontwikkeling per bedrijfssector volgens dit gunstige scenario. Terwijl in het basisscenario de werkgelegenheid in de metaalindustrie afneemt, zal deze in het gunstige scenario licht toenemen. Voor de sector overige industrie wordt nu eveneens een lichte groei verwacht. In de sector chemie zal de werkgelegenheid zelfs fors toenemen. Ook de bouwsector zal in dit scenario een aanzienlijk grotere werkgelegenheidsgroei doormaken dan in het basisscenario. In de voedings- en genotmiddelenindustrie zal de werkgelegenheid blijven afnemen, zij het in mindere mate dan in het basisscenario. De werkgelegenheidsgroei in de sector energie verandert niet ten opzichte van het basisscenario. In de dienstensectoren zal de werkgelegenheid echter wel iets sterker groeien. De werkgelegenheid bij de sector openbaar bestuur, politie, defensie en onderwijs zal ook in het gunstige scenario dalen.

Zoals tabel 6.2 laat zien, zijn de werkgelegenheidsontwikkelingen in dit scenario voor alle technische beroepen gunstiger. De totale groei van de werkgelegenheid voor de technische beroepen zal nu naar verwachting in de komende jaren ongeveer $1,1 \%$ per jaar bedragen, hetgeen overeenkomt met het algemene beeld. De hogere technische beroepen zullen echter het meest van de hogere economische groei profiteren. Met name voor de 'hogere bouwberoepen', de 'hogere en middelbare technische, ambachts- en industrieberoepen' en de 'hogere elektrotechnische beroepen' zal de werkgelegenheid in dit scenario flink toenemen. Vooral de forse groei van de 'hogere elektrotechnische beroepen' is opvallend, daar de werkgelegenheidsgroei voor deze beroepen in het basisscenario vrij klein is. Dit is te verklaren door het feit dat de 'hogere elektrotechnische beroepen' erg conjunctuurgevoelig zijn; zij profiteren daarom meer dan andere beroepen van de gunstigere economische ontwikkelingen die in dit scenario worden verwacht. Verder zal de werkgelegenheidsgroei voor de 'lagere grafische beroepen' ook zeer groot zijn. Terwijl in het basisscenario de werkgelegenheid voor de 'lagere hout- en papierberoepen' en de 'middelbare metaalberoepen' licht zal dalen, wordt in het gunstige scenario een geringe werkgelegenheidstoename voor deze beroepen verwacht.

Tabel 6.2

Verwachte ontwikkeling van het aantal werkenden per beroepssegment 1993-2000 gunstig werkgelegenheidsscenario (gemiddelde jaarlijkse groei)

\begin{tabular}{|c|c|c|}
\hline $\begin{array}{l}\text { ROA- } \\
\text { code }\end{array}$ & beroepssegment & $\begin{array}{c}1993-2000 \\
\%\end{array}$ \\
\hline $\begin{array}{l}301 \\
302 \\
303 \\
311 \\
321 \\
331 \\
341 \\
351 \\
361 \\
362 \\
363 \\
371 \\
372 \\
373 \\
381 \\
391 \\
392 \\
393\end{array}$ & $\begin{array}{l}\text { Lagere technische, ambachts- en industrieberoepen } \\
\text { Middelbare technische, ambachts- en industrieberoepen } \\
\text { Hogere technische, ambachts- en industrieberoepen } \\
\text { Lagere voedings- en genotmiddelenberoepen } \\
\text { Lagere textielberoepen } \\
\text { Lagere hout- en papierberoepen } \\
\text { Lagere grafische beroepen } \\
\text { Lagere chemische beroepen } \\
\text { Lagere metaalberoepen } \\
\text { Middelbare metaalberoepen } \\
\text { Hogere metaalberoepen } \\
\text { Lagere elektrotechnische beroepen } \\
\text { Middelbare elektrotechnische beroepen } \\
\text { Hogere elektrotechnische beroepen } \\
\text { Lagere bouwmaterialen-, glas- en aardewerkberoepen } \\
\text { Lagere bouw- en installatieberoepen } \\
\text { Middelbare bouw- en installatieberoepen } \\
\text { Hogere bouw- en installatieberoepen }\end{array}$ & $\begin{array}{r}1,4 \\
2,7 \\
2,0 \\
-0,5 \\
-2,0 \\
0,3 \\
2,1 \\
0,6 \\
-0,2 \\
0,1 \\
1,8 \\
-0,6 \\
0,8 \\
2,7 \\
-1,6 \\
0,6 \\
0,2 \\
2,5\end{array}$ \\
\hline & Totaal technische beroepen & 1,1 \\
\hline
\end{tabular}


Deze positieve werkgelegenheidsontwikkelingen voor de technische beroepen leiden vanzelfsprekend tot een hogere uitbreidingsvraag voor de technische opleidingen. Tabel 6.3 geeft de verwachte uitbreidingsvraag naar opleidingsniveau en -richting in het gunstige scenario. De vraag naar alle opleidingen neemt toe ten opzichte van het basisscenario. De opleidingen op WO- en HBO-niveau lijken echter wat meer van een gunstige economische ontwikkeling te profiteren.

Tabel 6.3

Verwachte uitbreidingsvraag technische opleidingen naar opleidingsniveau en -richting 1993-2000 gunstig werkgelegenheidsscenario (totaal aantal en gemiddeld jaarlijks percentage)

Wetenschappelijk onderwijs

Wiskunde en natuurwetenschappen

Technisch

bouwkunde/civiele techniek

werktuigbouwkunde

elektrotechniek/informatica

Hoger beroepsonderwijs

Technisch laboratorium

Technisch

bouwkunde/weg- en waterbouwkunde

werktuigbouwkunde

elektrotechniek/informatica

26.500

7.200

6.400

9.600

1.400

71.300

18.200

2.200

5.300

1.100

8.500

5.300

14.000

1.900 elektrotechniek
procestechniek

Voorbereidend beroepsonderwijs

Technisch

bouwtechniek

installatietechniek

metaalkunde

motorvoertuigentechniek

elektrotechniek

grafische techniek

consumptieve techniek

$\begin{array}{rr}-12.700 & -0,4 \\ -1.500 & -0,2 \\ 100 & 0,1 \\ -5.200 & -0,5 \\ -1.600 & -0,5 \\ -2.500 & -0,6 \\ 200 & 0,4 \\ -600 & -0,4\end{array}$

Bron: ROA

De uitbreidingsvraag voor technisch opgeleiden op WO-niveau bedraagt in dit scenario ongeveer 19.000. Dat is ruim 4.000 meer dan in het basisscenario. Hiermee komt de verwachte uitbreidingsvraag naar technisch opgeleiden op WO-niveau in het gunstige scenario op $4,2 \%$ gemiddeld per jaar. De richting elektrotechniek/informatica profiteert het meest van de positieve economische ontwikkelingen in dit scenario. De uitbreidingsvraag bedraagt voor deze richting $4,6 \%$ per jaar. Deze forse toename is toe 
te schrijven aan de gunstige werkgelegenheidsontwikkelingen die voor de 'hogere elektrotechnische beroepen' worden verwacht. De uitbreidingsvraag voor de studies wiskunde en natuurwetenschappen stijgt in verhouding wat minder ten opzichte van het basisscenario dan de andere technische opleidingen op WO-niveau. Deze opleiding is, doordat een deel van de afgestudeerden als leerkracht in het onderwijs terechtkomt, niet zo conjunctuurgevoelig, zodat een opleving van de economie minder invloed heeft op de vraag naar arbeidskrachten die een dergelijke studie hebben afgerond.

De vraag naar technische opleidingen op HBO-niveau zal in het gunstige scenario met gemiddeld 2,9\% per jaar toenemen. In totaal bedraagt de uitbreidingsvraag voor deze opleidingen ruim 8.000 meer dan in het basisscenario. Ook hier is de vraagtoename relatief het grootst voor de richting elektrotechniek/informatica. Voor de opleiding HBO technisch laboratorium wordt in dit scenario een jaarlijkse vraagtoename van $2,9 \%$ verwacht. De uitbreidingsvraag voor MBO technici bedraagt in het gunstige scenario ruim 71.000 , hetgeen neerkomt op ongeveer $1,4 \%$ per jaar. Daarmee ligt de vraag naar MBO technici in dit scenario ruim 30.000 boven de uitbreidingsvraag in het basisscenario. De vraagtoename ten opzichte van het basisscenario is voor alle richtingen min of meer gelijk. De grootste uitbreidingsvraag wordt ook in dit scenario verwacht voor de richtingen bouwkunde, weg- en waterbouwkunde en procestechniek.

De negatieve uitbreidingsvraag voor de technische opleidingen op VBO-niveau neemt met ongeveer de helft af ten opzichte van het basisscenario. De opleidingen VBO installatietechniek en VBO grafische techniek kennen nu zelfs een kleine positieve uitbreidingsvraag van respectievelijk $0,1 \%$ en $0,4 \%$ per jaar. In het basisscenario wordt voor beide opleidingen nog een afname van de vraag met respectievelijk $0,4 \%$ en $0,2 \%$ verwacht.

In tabel 6.4 worden voor dit gunstige werkgelegenheidsscenario de arbeidsmarktperspectieven voor schoolverlaters c.q. de problemen die werkgevers bij de personeelswerving mogen verwachten gepresenteerd. Voor de technische opleidingen op WO- en HBO-niveau is het arbeidsmarktperspectief goed. Ook in het basisscenario worden voor al deze opleidingen goede perspectieven verwacht. De opleiding HBO elektrotechniek die in het basisscenario een redelijk arbeidsmarktperspectief heeft, heeft in dit scenario een goed arbeidsmarktperspectief. Dit betekent dat de positieve economische ontwikkelingen in dit scenario gepaard zullen gaan met grote problemen bij de personeelsvoorziening van hoger opgeleid technisch personeel.

De opleiding MBO technisch laboratorium heeft in dit scenario een redelijk arbeidsmarktperspectief. Dat betekent dat bij een gunstige economische ontwikkeling er bij deze opleiding een redelijk grote kans op knelpunten bij de personeelsvoorziening bestaat. Voor technische opleidingen op MBO-niveau blijft het arbeidsmarktperspectief ook in het gunstige scenario in het algemeen slechts matig. Er zijn echter enkele opleidingen op MBO-niveau waarvoor het arbeidsmarktperspectief duidelijk verbetert ten opzichte van het basisscenario. Dat zijn met name de opleidingen MBO bouwkunde en MBO procestechniek, die in het gunstige werkgelegenheidsscenario beide goede perspectieven hebben. Bij opleiding MBO bouwkunde is in het basisscenario nog sprake van een redelijk arbeidsmarktperspectief, terwijl de opleiding MBO procestechniek in dat scenario zelfs een matig arbeidsmarktperspectief heeft. Hieruit blijkt dat de perspectieven voor deze opleidingen sterk afhankelijk zijn van de economische ontwikkelingen. Terwijl in het basisscenario de kansen op knelpunten bij de personeelsvoorziening voor deze opleiding klein zijn, kunnen bij de positieve economische ontwikkelingen in dit scenario wel duidelijk knelpunten ontstaan. De arbeidsmarktperspectieven voor schoolverlaters van de richtingen metaalkunde en elektrotechniek verbeteren eveneens. Deze worden in het gunstige scenario als respectievelijk redelijk en matig getypeerd. 
De arbeidsmarktperspectieven voor technische opleidingen op VBO-niveau zijn in het gunstige scenario in het algemeen genomen goed. $\mathrm{Er}$ is minder sprake van verdringing van VBO'ers door MBO'ers, omdat het aanbodoverschot van MBO'ers minder groot zal zijn. Vooral bij de opleiding VBO bouwtechniek is er sprake van gunstige arbeidsmarktperspectieven voor schoolverlaters. De goede perspectieven voor zowel VBO als MBO bouwkunde kunnen voor problemen bij de personeelsvoorziening in de sterk groeiende bouwsector leiden. Tevens verbetert het perspectief voor de opleiding VBO motorvoertuigentechniek. Het arbeidsmarktperspectief voor deze opleiding is nu redelijk, terwijl dit perspectief in het basisscenario slechts matig is. Dit betekent eveneens dat de kans op knelpunten bij de personeelsvoorziening bij deze opleiding redelijk groot is.

Tabel 6.4

Verwacht arbeidsmarktperspectief c.q. verwachte kans op knelpunten bij de personeelsvoorziening voor technische opleidingen naar opleidingsniveau en -richting 2000 gunstig werkgelegenheidsscenario.

\begin{tabular}{|c|c|c|c|}
\hline Opleidingsniveau en -richting & $\begin{array}{l}\text { indicator toekomstige } \\
\text { arbeidsmarktsituatie }\end{array}$ & $\begin{array}{l}\text { arbeidsmarkt- } \\
\text { perspectief }\end{array}$ & $\begin{array}{l}\text { kans op knelpunten bij } \\
\text { personeelsvoorziening }\end{array}$ \\
\hline \multicolumn{4}{|l|}{ Wetenschappelijk onderwijs } \\
\hline Wiskunde en natuurwetenschappen & 0,81 & goed & groot \\
\hline $\begin{array}{l}\text { Technisch } \\
\text { bouwkunde/civiele techniek } \\
\text { werktuigbouwkunde } \\
\text { elektrotechniek/informatica }\end{array}$ & $\begin{array}{l}0,85 \\
0,69 \\
0,92 \\
0,90\end{array}$ & $\begin{array}{l}\text { goed } \\
\text { goed } \\
\text { goed } \\
\text { goed }\end{array}$ & $\begin{array}{l}\text { groot } \\
\text { groot } \\
\text { groot } \\
\text { groot }\end{array}$ \\
\hline \multicolumn{4}{|l|}{ Hoger beroepsonderwijs } \\
\hline Technisch laboratorium & 0,87 & goed & groot \\
\hline $\begin{array}{l}\text { Technisch } \\
\text { bouwkunde/weg- en waterbouwkunde } \\
\text { werktuigbouwkunde } \\
\text { elektrotechniek/informatica }\end{array}$ & $\begin{array}{l}0,88 \\
0,76 \\
0,95 \\
0,97\end{array}$ & $\begin{array}{l}\text { goed } \\
\text { goed } \\
\text { goed } \\
\text { goed }\end{array}$ & $\begin{array}{l}\text { groot } \\
\text { groot } \\
\text { groot } \\
\text { groot }\end{array}$ \\
\hline \multicolumn{4}{|l|}{ Middelbaar beroepsonderwijs } \\
\hline Technisch laboratorium & 1,04 & redelijk & redelijk \\
\hline $\begin{array}{l}\text { Technisch } \\
\text { bouwkunde } \\
\text { weg- en waterbouwkunde } \\
\text { metaalkunde } \\
\text { fijnmechanische techniek } \\
\text { werktuigbouwkunde } \\
\text { motorvoertuigentechniek } \\
\text { elektrotechniek } \\
\text { procestechniek }\end{array}$ & $\begin{array}{l}1,06 \\
0,99 \\
1,09 \\
1,05 \\
0,91 \\
1,08 \\
1,18 \\
1,13 \\
1,00\end{array}$ & $\begin{array}{l}\text { matig } \\
\text { goed } \\
\text { matig } \\
\text { redelijk } \\
\text { goed } \\
\text { matig } \\
\text { slecht } \\
\text { matig } \\
\text { goed }\end{array}$ & $\begin{array}{l}\text { klein } \\
\text { groot } \\
\text { klein } \\
\text { redelijk } \\
\text { groot } \\
\text { klein } \\
\text { zeer klein } \\
\text { klein } \\
\text { groot }\end{array}$ \\
\hline \multicolumn{4}{|l|}{ Voorbereidend beroepsonderwijs } \\
\hline $\begin{array}{l}\text { Technisch } \\
\text { bouwtechniek } \\
\text { installatietechniek } \\
\text { metaalkunde } \\
\text { motorvoertuigentechniek } \\
\text { elektrotechniek } \\
\text { grafische techniek } \\
\text { consumptieve techniek }\end{array}$ & $\begin{array}{l}1,00 \\
1,00 \\
1,08 \\
1,01 \\
1,04 \\
1,08 \\
1,01 \\
1,12\end{array}$ & $\begin{array}{l}\text { goed } \\
\text { goed } \\
\text { matig } \\
\text { redelijk } \\
\text { redelijk } \\
\text { matig } \\
\text { redelijk } \\
\text { matig }\end{array}$ & $\begin{array}{l}\text { groot } \\
\text { groot } \\
\text { klein } \\
\text { redelijk } \\
\text { redelijk } \\
\text { klein } \\
\text { redelijk } \\
\text { klein }\end{array}$ \\
\hline
\end{tabular}

Bron: ROA 


\subsection{Het VUT/WAO-scenario}

Het alternatieve scenario voor de vervangingsvraag gaat er van uit dat er de komende jaren sprake zal zijn van een lagere netto uitstroom uit het arbeidsproces. Er zullen minder mensen met vervroegd pensioen gaan. Bovendien zullen er de komende jaren minder mensen uittreden als gevolg van arbeidsongeschiktheid. In dit scenario wordt er dus vanuit gegaan dat de recentelijk genomen maatregelen om het aantal arbeidsongeschikten terug te dringen in meerdere of mindere mate succesvol zullen zijn. Dit betekent concreet dat de netto uitstroom van 50- tot 59-jarigen in de komende jaren met een kwart zal dalen en de netto uitstroom van 40 - tot 54 -jarigen met één tiende.

Tabel 6.5

Verwachte vervangingsvraag technische opleidingen naar opleidingsniveau en -richting 1993-2000 VUTMAO-scenario (totaal aantal en gemiddeld jaarlijks percentage)

Opleidingsniveau en -richting

aantal

$\%$

Wetenschappelijk onderwijs

Wiskunde en natuurwetenschappen

6.400

Technisch

14.400

5.400

2.300

2.500

3,1

bouwkunde/civiele techniek

werktuigbouwkunde

3,6

elektrotechniek/informatica

Hoger beroepsonderwijs

Technisch laboratorium

3.500

1,8

Technisch

bouwkunde/weg- en waterbouwkunde werktuigbouwkunde

8.400

6.100

6.000

2,8

elektrotechniek/informatica

3,3

2,7

2,1

Middelbaar beroepsonderwijs

Technisch laboratorium

Technisch

bouwkunde

weg- en waterbouwkunde

metaalkunde

11.400

3.600

fijnmechanische techniek

14.200

motorvoertuigentechniek

10.400

elektrotechniek

19.400

procestechniek

1.700

Voorbereidend beroepsonderwijs

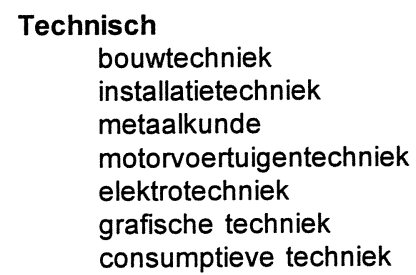

$\begin{array}{rr}92.600 & 2,5 \\ 23.300 & 2,3 \\ 1.400 & 1,5 \\ 26.300 & 2,5 \\ 7.100 & 2,1 \\ 8.700 & 1,9 \\ 1.700 & 2,9 \\ 3.300 & 2,0\end{array}$

Bron: ROA 
Tabel 6.5 geeft de verwachte vervangingsvraag naar opleidingsniveau en -richting in dit alternatieve scenario. De gemiddelde vervangingsvraag is voor alle opleidingen wat lager geworden. Wel blijkt de vervangingsvraag voor opleidingen waar deze in het basisscenario relatief hoog is, wat meer af te nemen dan voor opleidingen die reeds in het basisscenario een lage vervangingsvraag hebben. Dat is echter niet zo verwonderlijk, omdat de werkenden met de eerstgenoemde opleidingen in het algemeen in verhouding ouder zijn, en dus vaker in de leeftijdscategorieën 40 tot 54 jaar of 55 tot 59 jaar zullen zitten. De daling van de netto uitstroom van werkenden uit deze leeftijdscategorieën in verband met arbeidsongeschiktheid en vervroegde pensionering heeft derhalve meer invloed op de vervangingsvraag voor deze opleidingen.

Tabel 6.6

Verwacht arbeidsmarktperspectief, c.q. verwachte kans op knelpunten bij de personeelsvoorziening technische opleidingen naar opleidingsniveau en -richting 1993-2000 VUTMAO-scenario

\begin{tabular}{|c|c|c|c|}
\hline Opleidingsniveau en -richting & $\begin{array}{l}\text { indicator toekomstige } \\
\text { arbeidsmarktsituatie }\end{array}$ & $\begin{array}{l}\text { arbeidsmarkt- } \\
\text { perspectief }\end{array}$ & $\begin{array}{l}\text { kans op knelpunten bij } \\
\text { personeelsvoorziening }\end{array}$ \\
\hline \multicolumn{4}{|l|}{ Wetenschappelijk onderwijs } \\
\hline Wiskunde en natuurwetenschappen & 0,87 & goed & groot \\
\hline $\begin{array}{l}\text { Technisch } \\
\text { bouwkunde/civiele techniek } \\
\text { werktuigbouwkunde } \\
\text { elektrotechniek/informatica }\end{array}$ & $\begin{array}{l}0,86 \\
0,73 \\
0,96 \\
0,96\end{array}$ & $\begin{array}{l}\text { goed } \\
\text { goed } \\
\text { goed } \\
\text { goed }\end{array}$ & $\begin{array}{l}\text { groot } \\
\text { groot } \\
\text { groot } \\
\text { groot }\end{array}$ \\
\hline \multicolumn{4}{|l|}{ Hoger beroepsonderwijs } \\
\hline Technisch laboratorium & 0,90 & goed & groot \\
\hline $\begin{array}{l}\text { Technisch } \\
\text { bouwkunde/weg- en waterbouwkunde } \\
\text { werktuigbouwkunde } \\
\text { elektrotechniek/informatica }\end{array}$ & $\begin{array}{l}0,93 \\
0,80 \\
0,99 \\
1,04\end{array}$ & $\begin{array}{l}\text { goed } \\
\text { goed } \\
\text { goed } \\
\text { redelijk }\end{array}$ & $\begin{array}{l}\text { groot } \\
\text { groot } \\
\text { groot } \\
\text { redelijk }\end{array}$ \\
\hline \multicolumn{4}{|l|}{ Middelbaar beroepsonderwijs } \\
\hline Technisch laboratorium & 1,08 & matig & klein \\
\hline $\begin{array}{l}\text { Technisch } \\
\text { bouwkunde } \\
\text { weg- en waterbouwkunde } \\
\text { metaalkunde } \\
\text { fijnmechanische techniek } \\
\text { werktuigbouwkunde } \\
\text { motorvoertuigentechniek } \\
\text { elektrotechniek } \\
\text { procestechniek }\end{array}$ & $\begin{array}{l}1,14 \\
1,07 \\
1,17 \\
1,14 \\
0,98 \\
1,15 \\
1,25 \\
1,20 \\
1,07\end{array}$ & $\begin{array}{l}\text { matig } \\
\text { matig } \\
\text { slecht } \\
\text { matig } \\
\text { goed } \\
\text { matig } \\
\text { slecht } \\
\text { slecht } \\
\text { matig }\end{array}$ & $\begin{array}{l}\text { klein } \\
\text { klein } \\
\text { zeer klein } \\
\text { klein } \\
\text { groot } \\
\text { klein } \\
\text { zeer klein } \\
\text { zeer klein } \\
\text { klein }\end{array}$ \\
\hline \multicolumn{4}{|l|}{ Voorbereidend beroepsonderwijs } \\
\hline $\begin{array}{l}\text { Technisch } \\
\text { bouwtechniek } \\
\text { installatietechniek } \\
\text { metaalkunde } \\
\text { motorvoertuigentechniek } \\
\text { elektrotechniek } \\
\text { grafische techniek } \\
\text { consumptieve techniek }\end{array}$ & $\begin{array}{l}1,04 \\
1,05 \\
1,15 \\
1,05 \\
1,07 \\
1,11 \\
1,07 \\
1,15\end{array}$ & $\begin{array}{l}\text { redelijk } \\
\text { redelijk } \\
\text { matig } \\
\text { redelijk } \\
\text { matig } \\
\text { matig } \\
\text { matig } \\
\text { matig }\end{array}$ & $\begin{array}{l}\text { redelijk } \\
\text { redelijk } \\
\text { klein } \\
\text { redelijk } \\
\text { klein } \\
\text { klein } \\
\text { klein } \\
\text { klein }\end{array}$ \\
\hline
\end{tabular}

Bron: ROA 
De vervangingsvraag voor technisch opgeleiden op WO-niveau bedraagt in dit VUTMAO-scenario in de periode 1993-2000 14.400. Dat is ruim 1.000 minder dan in het basisscenario. Ook voor de studies wiskunde en de natuurwetenschappen daalt de vervangingsvraag fors ten opzichte van het basisscenario. De vervangingsvraag voor dit opleidingstype bedraagt ruim 6.000 , overeenkomend met ruim $2 \%$ gemiddeld per jaar. Naar verwachting worden in dit scenario bijna 26.000 mensen met een technische opleiding op HBO-niveau vervangen. De vervangingsvraag voor deze opleiding is met 1.400 gedaald ten opzichte van het basisscenario. Voor de opleidingen op MBO- en VBO-niveau daalt de vervangingsvraag respectievelijk met ongeveer 9.000 en 7.000 ten opzichte van het basisscenario.

Tabel 6.6 geeft de indicator toekomstige arbeidsmarktsituatie naar opleidingsniveau en -richting voor dit scenario. Voor bijna alle opleidingen worden de arbeidsmarktperspectieven wat slechter. De kans op knelpunten bij de personeelsvoorziening nemen daarmee wat af. De arbeidsmarktperspectieven voor de verschillende opleidingen veranderen echter niet noemenswaardig. Een redelijk forse afname van het aantal mensen dat vervroegd uittreedt, of een afname van het aantal arbeidsongeschikten heeft weinig invloed op de arbeidsmarktperspectieven voor schoolverlaters.

\subsection{Het stapelscenario}

Het alternatieve scenario voor de instroom van schoolverlaters gaat uit van ander doorstroomgedrag in het voltijdonderwijs. Daarbij wordt er in de eerste plaats van uitgegaan dat meer VWO-leerlingen kiezen voor een technische studie. Bovendien is er in dit scenario bij de technische opleidingen sprake van een hogere doorstroom van MBO naar HBO en van HBO naar WO, hetgeen overigens in tegenspraak is met de huidige beleidsvoornemens op dit terrein. Vanwege deze laatste veronderstelling wordt dit scenario getypeerd als het stapelscenario.

In dit scenario wordt in de eerste plaats verondersteld dat er vanaf $199525 \%$ meer doorstroom zal zijn van het WWO naar het WO technisch. De invloed hiervan op het aantal afgestudeerden met een technische opleiding op WO-niveau is echter gering, doordat technische studies in het algemeen ten minste vijf jaar duren. Het effect zal dus pas over een aantal jaren zichtbaar zijn. Verder wordt verondersteld dat er ten opzichte van het basisscenario vanaf 1995 eveneens $25 \%$ meer gediplomeerden met een technische opleiding op MBO-niveau doorstromen naar een technische opleiding in het HBO. Als laatste wordt in het stapelscenario uitgegaan van $25 \%$ meer doorstroom van het HBO technisch naar technische opleidingen op WO-niveau. Ook de extra arbeidsmarktinstroom van WO'ers met een technische opleidingsachtergrond zal als gevolg hiervan vrij gering zijn, doordat, zoals reeds is opgemerkt, de prognosetermijn te kort is om de veranderingen geheel door te laten werken. De eerste lichtig doorstromen die een verkort programma in het WO volgen komen pas aan het eind van de jaren '90 op de arbeidsmarkt.

Tabel 6.7 geeft een overzicht van de verwachte instroom van schoolverlaters met een technische opleidingsachtergrond naar opleidingsniveau en -richting in dit alternatieve scenario ${ }^{13}$. De arbeidsmarktinstroom vanuit de technische WO-opleidingen bedraagt in dit scenario ongeveer 24.000 . Dit is 3.000 meer dan in het basisscenario. De verwachte instroom van recent afgestudeerden bedraagt daarmee $4,8 \%$ gemiddeld per jaar. Bij een gelijkblijvende verdeling over de onderscheiden richtingen binnen het WO technisch, zal de instroom bij de opleidingen bouwkunde/civiele techniek maar weing toenemen: slechts 400 meer afgestudeerden tot het jaar 2000 . Voor de technische opleidingen op HBO-

13. De basisraming die voor het doorrekenen van de scenario's is gebruikt, wijkt iets af van de in hoofdstuk 4 gehanteerde Referentieraming 1994. Hierdoor treden er nog enkele andere kleine verschillen op. 
niveau, alsmede de opleiding HBO technisch laboratorium neemt de arbeidsmarktinstroom eveneens toe ten opzichte van het basisscenario. De verwachte arbeidsmarktinstroom is voor het HBO technisch maar liefst bijna 5.000 meer dan in het basisscenario. Hiermee is de arbeidsmarktinstroom gemiddeld $4,3 \%$ per jaar.

De arbeidsmarktinstroom vanuit technische $\mathrm{MBO}$-opleidingen bedraagt in het stapelscenario ongeveer 220.000 , dit komt overeen met 3,9\% gemiddeld per jaar. Hiermee is de instroom van schoolverlaters naar de arbeidsmarkt bijna 10.000 minder dan in het basisscenario. In dit stapelscenario zijn er verder geen aanpassingen verondersteld ten aanzien van de doorstroom vanuit het VBO. De arbeidsmarktinstroom van VBO'ers blijft derhalve vrijwel hetzelfde als is het basisscenario.

Tabel 6.7

Verwachte instroom van technische opgeleide schoolverlaters naar opleidingsniveau en -richting 2000 stapelscenario (totaal aantal en gemiddeld jaarlijks percentage)

Opleidingsniveau en -richting

aantal

$\%$

Wetenschappelijk onderwijs

Wiskunde en natuurwetenschappen

8.700

Technisch

23.500

3.800

5.200

werktuigbouwkunde

6.300

4,8

6,7

elektrotechniek/informatica

$\begin{array}{ll}7.100 & 3,5\end{array}$

Technisch laboratorium

40.400

6.200

12.300

16.900

4,3

bouwkunde/weg- en waterbouwkunde

werktuigbouwkunde

6,2

Middelbaar beroepsonderwijs

Technisch laboratorium

3.900

3,8

Technisch

bouwkunde

218.000

41.900

6.000

17.900

metaalkunde

2.000
25.500

fijnmechanische techniek

motorvoertuigentechniek

27.000

elektrotechniek

procestechniek

49.100

2.900

2,5

5,1

5,4

Voorbereidend beroepsonderwijs

Technisch

$\begin{array}{rr}54.800 & 1,5 \\ 12.200 & 1,2 \\ 1.600 & 1,7 \\ 16.800 & 1,6 \\ 4.500 & 1,4 \\ 8.100 & 1,8 \\ 1.300 & 2,3 \\ 3.900 & 2,3\end{array}$

Bron: ROA

In tabel 6.8 wordt voor dit scenario een overzicht gegeven van de toekomstige arbeidsmarktsituatie voor de verschillende opleidingen. Voor de technische opleidingen op WO- en HBO-niveau wordt, evenals in 
het basisscenario, een in het algemeen goed arbeidsmarktperspectief verwacht. De WO-studies werktuigbouwkunde en elektrotechniek/informatica, die in het basisscenario een goed arbeidsmarktperspectief hebben, hebben in dit scenario een redelijk arbeidsmarktperspectief. De kans dat werkgevers in de toekomst knelpunten bij de personeelsvoorziening zullen ondervinden, neemt derhalve wat af. Ook voor de HBO-opleidingen werktuigbouwkunde en elektrotechniek/informatica is het arbeidsmarktperspectief voor schoolverlaters iets slechter dan in het basisscenario. De opleiding werktuigbouwkunde heeft in dit scenario een redelijk perspectief, terwijl voor elektrotechniek het arbeidsmarktperspectief zelfs als matig wordt getypeerd. De kans dat zich in het stapelscenario arbeidsmarktknelpunten gaan voordoen moet voor deze laatste opleiding vrij klein worden geacht.

Tabel 6.8

Verwacht arbeidsmarktperspectief, c.q. verwachte kans op knelpunten bij de personeelsvoorziening technische opleidingen naar opleidingsniveau en -richting 1993-2000 stapelscenario.

\begin{tabular}{|c|c|c|c|}
\hline Opleidingsniveau en -richting & $\begin{array}{l}\text { indicator toekomstige } \\
\text { arbeidsmarktsituatie }\end{array}$ & $\begin{array}{l}\text { arbeidsmarkt- } \\
\text { perspectief }\end{array}$ & $\begin{array}{l}\text { kans op knelpunten bij } \\
\text { personeelsvoorziening }\end{array}$ \\
\hline \multicolumn{4}{|l|}{ Wetenschappelijk onderwijs } \\
\hline Wiskunde en natuurwetenschappen & 0,86 & goed & groot \\
\hline $\begin{array}{l}\text { Technisch } \\
\text { bouwkunde/civiele techniek } \\
\text { werktuigbouwkunde } \\
\text { elektrotechniek/informatica }\end{array}$ & $\begin{array}{l}0,88 \\
0,73 \\
1,01 \\
1,01\end{array}$ & $\begin{array}{l}\text { goed } \\
\text { goed } \\
\text { redelijk } \\
\text { redelijk }\end{array}$ & $\begin{array}{l}\text { groot } \\
\text { groot } \\
\text { redelijk } \\
\text { redelijk }\end{array}$ \\
\hline \multicolumn{4}{|l|}{ Hoger beroepsonderwijs } \\
\hline Technisch laboratorium & 0,92 & goed & groot \\
\hline $\begin{array}{l}\text { Technisch } \\
\text { bouwkunde/weg- en waterbouwkunde } \\
\text { werktuigbouwkunde } \\
\text { elektrotechniek/informatica }\end{array}$ & $\begin{array}{l}0,95 \\
0,81 \\
1,02 \\
1,07\end{array}$ & $\begin{array}{l}\text { goed } \\
\text { goed } \\
\text { redelijk } \\
\text { matig }\end{array}$ & $\begin{array}{l}\text { groot } \\
\text { groot } \\
\text { redelijk } \\
\text { klein }\end{array}$ \\
\hline \multicolumn{4}{|l|}{ Middelbaar beroepsonderwijs } \\
\hline Technisch laboratorium & 1,06 & matig & klein \\
\hline $\begin{array}{l}\text { Technisch } \\
\text { bouwkunde } \\
\text { weg- en waterbouwkunde } \\
\text { metaalkunde } \\
\text { fijnmechanische techniek } \\
\text { werktuigbouwkunde } \\
\text { motorvoertuigentechniek } \\
\text { elektrotechniek } \\
\text { procestechniek }\end{array}$ & $\begin{array}{l}1,11 \\
1,04 \\
1,15 \\
1,10 \\
0,96 \\
1,13 \\
1,22 \\
1,17 \\
1,05\end{array}$ & $\begin{array}{l}\text { matig } \\
\text { redelijk } \\
\text { matig } \\
\text { matig } \\
\text { goed } \\
\text { matig } \\
\text { slecht } \\
\text { slecht } \\
\text { redelijk }\end{array}$ & $\begin{array}{l}\text { klein } \\
\text { redelijk } \\
\text { klein } \\
\text { klein } \\
\text { groot } \\
\text { klein } \\
\text { zeer klein } \\
\text { zeer klein } \\
\text { redelijk }\end{array}$ \\
\hline \multicolumn{4}{|l|}{ Voorbereidend beroepsondenwijs } \\
\hline $\begin{array}{l}\text { Technisch } \\
\text { bouwtechniek } \\
\text { installatietechniek } \\
\text { metaalkunde } \\
\text { motorvoertuigentechniek } \\
\text { elektrotechniek } \\
\text { grafische techniek } \\
\text { consumptieve techniek }\end{array}$ & $\begin{array}{l}1,02 \\
1,02 \\
1,13 \\
1,03 \\
1,05 \\
1,09 \\
1,05 \\
1,13\end{array}$ & $\begin{array}{l}\text { redelijk } \\
\text { redelijk } \\
\text { matig } \\
\text { redelijk } \\
\text { redelijk } \\
\text { matig } \\
\text { redelijk } \\
\text { matig }\end{array}$ & $\begin{array}{l}\text { redelijk } \\
\text { redelijk } \\
\text { klein } \\
\text { redelijk } \\
\text { redelijk } \\
\text { klein } \\
\text { redelijk } \\
\text { klein }\end{array}$ \\
\hline
\end{tabular}

Bron: ROA 
Ondanks de veronderstelde extra doorstroom van technisch opgeleide MBO'ers naar een technische HBO-opleiding blijft het perspectief voor deze MBO'ers op de arbeidsmarkt in dit scenario matig. Alleen de opleidingen weg- en waterbouwkunde en procestechniek krijgen in vergelijking met het basisscenario een ietwat gunstiger arbeidsmarktperspectief. Terwijl de opleiding weg- en waterbouwkunde in het basisscenario een slecht arbeidsmarktperspectief heeft, wordt in dit stapelscenario het arbeidsmarktperspectief voor deze opleiding als matig getypeerd. Het arbeidsmarktperspectief voor de opleiding procestechniek is nu redelijk, terwijl dit perspectief in het basisscenario slechts matig is. Dit betekent echter ook dat werkgevers vaker problemen zullen ondervinden bij het recruteren van personeel met deze opleidingsachtergrond.

Voor de technische opleidingen op VBO-niveau verandert er in vergelijking met het basisscenario vrijwel niets. De arbeidsmarktperspectieven voor deze opleidingen zijn in het algemeen redelijk. Alleen voor de opleiding motorvoertuigentechniek verandert de typering van het perspectief. In het basisscenario werd het perspectief nog als matig getypeerd, maar in dit stapelscenario kan worden gesproken van een redelijk arbeidsmarktperspectief. 


\section{Conclusies en beleidsimplicaties}

In dit rapport zijn de huidige en de te verwachten ontwikkelingen op de arbeidsmarkt voor technisch opgeleiden in kaart gebracht. Hierbij is ten eerste ingegaan op een groot aantal actuele gegevens en indicatoren over de arbeidsmarktpositie van zowel de werkzame beroepsbevolking als de schoolverlaters en recent afgestudeerden met een technische opleidingsachtergrond. Ten tweede is een toekomstverkenning voor de arbeidsmarkt van technisch opgeleiden opgesteld. Daarbij zijn zowel een basisprognose als enkele alternatieve scenario's doorgerekend.

Van de totale werkzame bevolking hebben ruim 1,4 miljoen arbeidskrachten een technische opleidingsachtergrond. Daarvan heeft bijna de helft een opleiding op MBO-niveau afgerond. De grootste richtingen daarbinnen zijn bouwkunde en elektrotechniek. Verder heeft een groot aantal arbeidskrachten een opleiding VBO bouwtechniek of VBO metaalkunde als achtergrond. Zowel het percentage vrouwelijke arbeidskrachten als het percentage deeltijdwerkers is bij de technisch opgeleiden in het algemeen erg klein.

De technische opleidingen op VBO-niveau kennen verhoudingsgewijs de hoogste werkloosheid. Op dit niveau worden relatief gezien ook de meeste arbeidskrachten in hun kwalificaties onderbenut. Ook bij de MBO-opleidingen metaalkunde en procestechniek is de mate van onderbenutting vrij hoog. De conjunctuurgevoeligheid van de werkgelegenheid is bij nagenoeg alle technische opleidingen vrij groot. De werkgelegenheid voor de technisch opgeleiden op MBO-niveau is daarbij in het algemeen verhoudingsgewijs het meest afhankelijk van de conjuncturele ontwikkelingen. Vooral bij MBO bouwkunde is er sprake van een erg conjunctuurgevoelige werkgelegenheidsontwikkeling, maar ook de werkgelegenheid voor arbeidskrachten met een opleiding VBO installatietechniek is erg sterk aan conjuncturele fluctuaties onderhevig. De arbeidskrachten met een technische opleiding op MBO- of VBO-niveau hebben in het algemeen de meeste mogelijkheden om uit te wijken naar andere segmenten op de arbeidsmarkt. De VBO-opleiding installatietechniek heeft echter een zeer beperkt aantal uitwijkmogelijkheden naar beroepen op een aansluitend of hoger functieniveau. Vooral bij de opleidingen MBO bouwkunde en VBO grafische techniek is het aantal uitwijkmogelijkheden naar andere bedrijfsklassen beperkt.

Bij de schoolverlaters en recent afgestudeerden met een technische opleidingsachtergrond blijkt dat HBO'ers op dit moment met de hoogste werkloosheid worden geconfronteerd. Het overgrote deel van de schoolverlaters en recent afgestudeerden met een technische opleiding heeft echter wel binnen drie maanden een baan gevonden. Voor een deel zijn dit echter tijdelijke banen, die afgewisseld worden met perioden van werkloosheid. De schoolverlaters met een technische opleidingsachtergrond op MBOniveau geven relatief gezien vaak aan dat de opleidingsvereisten voor de functie die zij uitoefenen lager zijn dan hun daadwerkelijke opleidingsniveau: ze worden onderbenut. De schoolverlaters van de opleidingen MBO bouwkunde, weg- en waterbouwkunde en technisch laboratorium worden in vergelijking met andere technische MBO-opleidingen minder onderbenut. De werkgelegenheid voor technisch opgeleide schoolverlaters en recent afgestudeerden is conjunctuurgevoeliger dan de werkgelegenheid voor de technische beroepsbevolking met dezelfde opleidingsachtergrond. Met name de schoolverlaters van de technische opleidingen op MBO- en VBO-niveau komen vaker in meer conjunctureel gevoelige sectoren terecht. De schoolverlaters van de opleidingen MBO bouwkunde, VBO bouwtechniek en VBO elektrotechniek zijn daarbij het meest afhankelijk van de conjunctuurgevoelige bedrijfssectoren. Verder blijkt dat de schoolverlaters veel minder flexibel op de arbeidsmarkt zijn dan degenen die al langer werkzaam zijn met een vergelijkbare technische opleidingsachtergrond. De uitwijkmogelijkheden van schoolverlaters en recent afgestudeerden zijn namelijk duidelijk geringer. Verder blijkt dat naarmate het onderwijsniveau van arbeidsmarktintreders lager is, er meer van mening zijn dat in de opleiding meer 
aandacht had moeten worden besteed aan vakkennis, informatica, het omgaan met apparatuur en het opdoen van praktijkervaring. Vooral kennis van informatica blijkt zelfs bij technisch opgeleiden een belangrijk knelpunt te zijn bij de overgang van het onderwijs naar de beroepspraktijk.

\section{Toekomstverkenning arbeidsmarkt technisch opgeleiden}

Het arbeidsmarktperspectief voor afgestudeerden met een technische opleiding op WO- of HBO-niveau is voor de komende jaren zonder meer goed te noemen. Dit betekent echter dat werkgevers naar alle waarschijnlijkheid de komende jaren zullen worden geconfronteerd met problemen ten aanzien van de werving van hoger opgeleide technici. Uit de confrontatie van vraag en aanbod blijkt dat er in het jaar 2000 met name een aanbodtekort wordt verwacht aan hoger opgeleide bouwkundigen en civiele technici. Naar verwachting zullen er de komende jaren ongeveer 1.500 tot 3.000 afgestudeerden te weinig van deze opleidingen op de arbeidsmarkt komen. Op WO-niveau is dat maar liefst tussen de $40 \%$ en $85 \%$ van de momenteel verwachte arbeidsmarktinstroom vanuit deze studie. Voor beide opleidingen geldt dat de instroom van afgestudeerden relatief erg klein is, terwijl de verwachte totale vraag naar arbeidskrachten met deze opleidingen, met name ook vanwege de hoge vervangingsvraag, relatief groot is. Voor de andere technische opleidingen op WO- en HBO-niveau komt de vraag naar nieuwkomers ongeveer overeen met de verwachte arbeidsmarktinstroom van recent afgestudeerden. Dit betekent dat de arbeidsmarkt voor deze opleidingen min of meer in evenwicht is. Doordat echter vanwege het tekort aan bouwkundigen en civiel technisch ingenieurs op WO- en HBO-niveau een extra vraagimpuls voor de andere technische opleidingen ontstaat, zal ook hier sprake zijn van een grote kans op knelpunten bij de personeelsvoorziening. De arbeidsmarktperspectieven voor de toekomstige afgestudeerden zijn derhalve gunstig.

Voor technisch opgeleiden op MBO-niveau wordt in het jaar 2000 een aanbodoverschot van 15.000 tot 30.000 personen verwacht. Dit komt overeen met tussen de $6 \%$ en $13 \%$ van de totale arbeidsmarktinstroom in de periode vanaf 1993. De arbeidsmarktperspectieven voor schoolverlaters van deze opleidingen worden daarom in het algemeen als matig getypeerd. De opleidingen weg- en waterbouwkunde, motorvoertuigentechniek en elektrotechniek hebben zelfs een slecht perspectief op de arbeidsmarkt. De werkgevers zullen in het algemeen dan ook weinig knelpunten ondervinden bij het recruteren van technisch opgeleide MBO'ers. Alleen voor de opleiding MBO fijnmechanische techniek wordt een goed arbeidsmarktperspectief verwacht. De instroom van schoolverlaters met deze opleiding is relatief laag, terwijl vooral de toekomstige vervangingsbehoefte naar verwachting relatief groot zal zijn.

Er blijkt tot het jaar 2000 een tekort van 4.000 tot 7.500 nieuwkomers met een technische opleiding op VBO-niveau te ontstaan. Dit is $7 \%$ tot $14 \%$ van de totale arbeidsmarktinstroom in de periode $1993-2000$. De vraag naar technisch opgeleiden op VBO-niveau is relatief laag, maar de instroom van schoolverlaters met deze opleidingen is nog te klein om aan deze vraag te kunnen voldoen. Toch worden de arbeidsmarktperspectieven voor schoolverlaters van het VBO technisch in het algemeen niet als goed, maar slechts als redelijk getypeerd. Dit heeft te maken met het feit dat er een dreigend overschot is aan technisch opgeleiden op MBO-niveau. Dit betekent dat een deel van de VBO'ers zal worden verdrongen door MBO-schoolverlaters. Desalniettemin mag worden verwacht dat werkgevers in de komende jaren enige problemen zullen ondervinden bij het recruteren van technisch opgeleide VBO'ers.

\section{Alternatieve scenario's}

Naast het hierboven geschetste basisscenario zijn enkele alternatieve scenario's doorgerekend. Het eerste alternatieve scenario is het gunstige werkgelegenheidsscenario, waarbij wordt uitgegaan van de 
meest positieve voorspellingen van het CPB. Dit scenario leidt tot een hogere vraag naar technisch opgeleiden op alle niveaus. De opleidingen op WO- en HBO-niveau lijken echter relatief meer te profiteren van een gunstige economische ontwikkeling. Vooral voor de opleidingen WO en HBO elektrotechniek/informatica zal de vraag in het gunstige scenario sterk groeien. De arbeidsmarktperspectieven voor technisch opgeleiden op WO- en HBO-niveau zijn dan ook, evenals in het basisscenario, goed. Ook voor de technische opleidingen op VBO-niveau wordt in dit gunstige scenario een goed arbeidsmarktperspectief verwacht, hetgeen overigens wel betekent dat werkgevers moeite zullen ondervinden bij het werven van nieuw personeel. Ondanks een lichte toename van de vraag naar technisch opgeleiden op MBO-niveau, blijft het perspectief voor schoolverlaters van deze opleidingen in het algemeen toch slechts matig.

Het tweede alternatieve scenario betreft het VUT/WAO-scenario. Hierbij is verondersteld dat er de komende jaren minder mensen vervroegd met pensioen zullen gaan. Tevens wordt er van uitgegaan dat de maatregelen om de arbeidsmarktinstroom naar de arbeidsongeschiktheidsregelingen tegen te gaan succes hebben. De gemiddelde vervangingsvraag is voor alle onderscheiden opleidingen daardoor in dit scenario wat lager dan in het basisscenario. Ondanks deze wijzigingen in de arbeidsmarktuitstroom, treedt er opvallend genoeg in het algemeen geen wijziging op bij de typering van de arbeidsmarktperspectieven van schoolverlaters met een technische opleiding. Dit betekent dat met deze VUTMAOmaatregelen niet kan worden voorkomen dat er met name ten aanzien van de hoger opgeleide technici voor werkgevers recruteringsproblemen zullen ontstaan.

Het laatste alternatieve scenario dat is doorgerekend, kan worden getypeerd als het stapelscenario. Hierbij is verondersteld dat de doorstroom van WWO naar WO technisch, van MBO technisch naar HBO technisch en van HBO technisch naar WO technisch met een kwart toeneemt ten opzichte van deze doorstroom in het basisscenario. Het gevolg hiervan is dat de verwachte arbeidsmarktinstroom van schoolverlaters met een technische opleiding op WO- en HBO-niveau toeneemt, terwijl de instroom vanuit de technische opleidingen op MBO-niveau afneemt. De arbeidsmarktperspectieven voor technisch opgeleiden op WO- en HBO-niveau blijven desondanks evenals in het basisscenario in het algemeen goed. Ook deze extra instroom in de technische opleidingen kan de kans op knelpunten bij de personeelsvoorziening niet noemenswaard laten afnemen. Voor een deel heeft dat te maken met het feit dat de effecten van een hogere doorstroom naar het hoger technisch onderwijs pas over een aantal jaren zichtbaar zullen worden. Een uitzondering op dit algemene beeld wordt gevormd door de opleidingen werktuigbouwkunde en elektrotechniek/informatica op zowel WO- als op HBO-niveau. De arbeidsmarktperspectieven voor schoolverlaters van deze opleidingen worden iets ongunstiger getypeerd. Vanuit werkgeversoogpunt geredeneerd betekent dit dat de kans op recruteringsproblemen wat kleiner wordt. De toekomstige arbeidsmarktsituatie voor de technische opleidingen op MBO- en VBO-niveau blijft daarentegen nagenoeg hetzelfde als in het basisscenario.

\section{Vergelijking met vorige ROA-prognoses}

In het kader van het informatiesysteem onderwijs-arbeidsmarkt worden door het ROA sinds een aantal jaren prognoses van de toekomstige perspectieven voor schoolverlaters op de arbeidsmarkt opgesteld. In de jaren 1989, 1991 en 1993 zijn de te verwachten ontwikkelingen op de arbeidsmarkt tot respectievelijk 1992, 1994 en 1998 geschetst (zie respectievelijk De Grip, Heijke en Dekker, 1989, ROA, 1992 en ROA, 1993). Tabel 7.1 geeft voor de technische opleidingen, onderscheiden naar niveau en hoofdrichting, een overzicht van de in het verleden verwachte arbeidsmarktperspectieven tot respectievelijk 1992, 1994 en 1998, in vergelijking met de in dit rapport gepresenteerde arbeidsmarktperspectieven voor schoolverlaters tot het jaar 2000 volgens het basisscenario. 
Uit de tabel blijkt dat in de eerste ROA-prognose die betrekking had op de periode tot 1992 voor de studies wiskunde en natuurwetenschappen het toekomstige arbeidsmarktperspectief als redelijk werd getypeerd. Daarna wordt voor deze opleidingen steeds een goed arbeidsmarktperspectief verwacht. Vooral de arbeidsmarktinstroom van schoolverlaters werd in de periode 1985-1992 erg hoog ingeschat. Het arbeidsmarktperspectief voor de overige technische opleidingen op academisch niveau varieert in de loop van de jaren van redelijk tot goed. Voor de opleiding technisch laboratorium op HBO-niveau is het arbeidsmarktperspectief steeds als goed getypeerd. Het HBO technisch geeft hetzelfde beeld als wiskunde en natuurwetenschappen. Tot 1992 had het HBO technisch een redelijk arbeidsmarktperspectief, terwijl daarna het arbeidsmarktperspectief telkens gunstig is ingeschat. Uit deze vergelijking mag worden afgeleid dat de verwachte arbeidspositie voor de (toekomstige) afgestudeerden van het hoger technisch onderwijs sinds het begin van de jaren '90 sterk verbetert. Daarbij moet wel worden opgemerkt dat de werkgelegenheid voor technisch opgeleiden sterk conjunctuurgevoelig is, zodat bij een achterblijvende economische ontwikkeling (tijdelijke) perioden van werkloosheid kunnen ontstaan. Al met al betekent dit echter toch dat werkgevers de komende jaren in toenemende mate te maken zullen krijgen met problemen ten aanzien van de personeelsvoorziening.

Tabel 7.1

Verwacht arbeidsmarktperspectief technisch opgeleiden naar opleidingsniveau en hoofdrichting

\begin{tabular}{lllll}
\hline Opleidingsniveau en hoofdrichting & tot 1992 & tot 1994 & tot 1998 & tot 2000 \\
\hline & & & & \\
WO Wiskunde en natuurwetenschappen & redelijk & goed & goed & goed \\
WO Technisch & redelijk & goed & redelijk & goed \\
HBO Technisch laboratorium & goed & goed & goed & goed \\
HBO Technisch & redelijk & goed & goed & goed \\
MBO Technisch laboratorium & redelijk & redelijk & goed & matig \\
MBO Technisch & redelijk & matig & matig & matig \\
VBO Technisch & goed & matig & matig & redelijk
\end{tabular}

Bron: ROA

Opvallend zijn de veranderingen in het verwachte arbeidsmarktperspectief voor de MBO-opleiding technisch laboratorium. Zowel tot 1992 als tot 1994 werd voor deze opleiding een redelijk perspectief op de arbeidsmarkt verwacht. Het arbeidsmarktperspectief tot 1998 wordt zelfs als goed getypeerd, maar in dit rapport wordt gesproken van een matig perspectief voor het jaar 2000. Het verwachte arbeidsmarktperspectief voor het MBO technisch wordt in de loop van de jaren iets minder gunstig. In de ROAprognoses van 1989 werd voor het jaar 1992 een redelijk arbeidsmarktperspectief verwacht. In de daarop volgende prognoses worden de arbeidsmarktperspectieven voor schoolverlaters van deze opleidingen echter telkens als matig getypeerd. De arbeidsmarktperspectieven voor schoolverlaters van het VBO technisch werden door het ROA voor de periode tot 1992 als gunstig ingeschat. Uit de inmiddels uitgevoerde evaluatiestudie is echter gebleken dat deze inschatting voor schoolverlaters te positief is geweest. Achteraf gezien zou de typering matig beter op zijn plaats zijn geweest (zie Borghans, Van Eijs en De Grip, 1994) $)^{14}$. Ook voor 1994 en 1998 wordt het arbeidsmarktperspectief als matig getypeerd. In dit rapport vindt er wat dat betreft een omslag plaats en wordt een redelijk

14. Ook voor de opleidingstypen WO Wiskunde en natuurwetenschappen, HBO Technisch laboratorium en MBO Technisch zijn de arbeidsmarktperspectieven voor schoolverlaters tot 1992 achteraf gezien iets te gunstig ingeschat. Het verschil is echter niet zo groot als bij VBO Technisch. 
perspectief voor de schoolverlaters van het VBO technisch verwacht. De kans dat zich ook hier arbeidsmarktknelpunten zullen voordoen neemt derhalve toe.

\section{Beleidsimplicaties}

Concluderend kan worden gesteld dat de arbeidsmarkt voor technisch opgeleiden ook de komende jaren in het centrum van de belangstelling zal blijven staan. De resultaten van dit onderzoek sluiten in belangrijke mate aan op de verwachtingen die reeds eerder zijn uitgesproken. Wel biedt dit rapport op een aantal punten belangrijke aanvullende inzichten, die het overheidsbeleid ten aanzien van het stimuleren van het technisch onderwijs meer richting kunnen geven.

In de hier uitgevoerde toekomstverkenning is voor het eerst onderscheid gemaakt naar de binnen het technisch onderwijs onderscheiden vakrichtingen. Een opvallende conclusie is daarbij dat de knelpunten op de arbeidsmarkt voor technisch opgeleiden vooral bij de richtingen bouwkunde en weg- en waterbouwkunde erg nijpend zullen zijn. Met de toekomstige instroom van schoolverlaters kan niet aan de vraagverwachtingen worden voldaan. Juist in een periode waarin mogelijk veel grootschalige projecten op stapel staan, zoals bijvoorbeeld de aanleg van de Betuwelijn, de hogesnelheidslijn, luchthaven Schiphol en de investeringen in de regio Rijnmond, is een voldoende aanbod aan hoogwaardig technisch geschoold personeel uitermate belangrijk. Wanneer het binnenlandse arbeidsaanbod ontoereikend is om aan de vraag naar arbeidskrachten die uit dergelijke projecten voortvloeit te kunnen voldoen, zal een (groter) deel van de werkgelegenheid 'weglekken' naar het buitenland.

De uitgevoerde scenario-analyses laten zien dat deze trends op de arbeidsmarkt voor technisch opgeleiden vrij robuust zijn. Zelfs bij een forse afname van de uitstroom van ouderen, bijvoorbeeld bij een gedeeltelijke afschaffing van de VUT, en het gelijktijdig terugdringen van de instroom in de WAO, blijft de typering van de toekomstige arbeidsmarktsituatie van technisch opgeleiden vrijwel onveranderd. Een wijziging in het keuze- of doorstroomgedrag binnen het onderwijs sorteert, gezien de opleidingsduur, pas over enkele jaren effect. Tot het jaar 2000 zal dit geen verlichting op de arbeidsmarkt voor hoger technisch opgeleiden kunnen brengen.

Een opvallende positie in het spectrum van technische opleidingen wordt ingenomen door de opleidingen op MBO-niveau. Hiertoe worden ook de opleidingen van het kort MBO en het leerlingwezen gerekend. Voor deze opleidingen wordt het arbeidsmarktperspectief voor schoolverlaters in het algemeen als matig getypeerd. Voor een deel is deze ongunstige typering het gevolg van het feit dat MBO'ers in toenemende mate banen zullen moeten accepteren die vroeger door VBO'ers werden vervuld. Ook de arbeidsmarktpostitie van VBO-schoolverlaters verzwakt hierdoor. In het kader van de beleidsdiscussie rondom het startkwalificatie-niveau op de arbeidsmarkt roept dit enkele vragen op. Er kan immers een discrepantie worden geconstateerd tussen aan de ene kant de intentie om het startkwalificatie-niveau op te leggen op het niveau van het primair leerlingwezen en aan de andere kant het voortbestaan van substantiële beroepsvelden op VBO-niveau. Als voorbeeld kunnen daarbij worden genoemd de beroepen van metselaar, tegelzetter, stukadoor, wegenbouwarbeider en plaatwerker (zie ook CBS, 1993).

De verschillen in arbeidsmarktperspectieven tussen de technische opleidingen op MBO-niveau enerzijds en HBO- en WO-niveau anderzijds kunnen tevens in het licht van de beleidsdiscussie over de 'stapelproblematiek' worden geplaatst (zie ook ROA, 1993). Op grond van de hier gepresenteerde resultaten, zou kunnen worden geconcludeerd dat het wenselijk is de doorstroom van het MBO naar het HBO voor de technische opleidingen niet af te remmen, maar juist te stimuleren. Daarbij moet echter worden 
bedacht dat de effecten van een dergelijke hogere doorstroom pas over enkele jaren zichtbaar zijn. Mede daarom moet deze oplossing als 'second-best' worden gezien. Een betere en meer efficiënte manier om de instroom in het hoger technisch onderwijs te laten toenemen, is door het vergroten van de slaagkans van de 'koninklijke' leerroute HAVO-HBO ten opzichte van de 'omweg' HAVO-MBO-HBO. Meer in het algemeen kan worden opgemerkt dat door het verbeteren van het intern rendement van de verschillende technische opleidingen de arbeidsmarkt voor (hoger) technisch opgeleiden sterk kan worden verlicht.

Dit brengt ons bij de moeilijke vraag op welke wijze de keuze voor de technische richting zou moeten worden gestimuleerd. Door Willems en De Grip (1993) is recentelijk nagegaan welke factoren het meest bepalend zijn bij de keuze van leerlingen voor al dan niet een technische opleiding. Daarbij is niet alleen gekeken naar de meer traditionele persoons- en achtergrondkenmerken, maar ook naar hun waardering voor techniek en bepaalde technologische ontwikkelingen en hun beeldvorming ten aanzien van het werkveld van technisch opgeleiden. Samen geven deze gegevens een beeld van het maatschappelijke draagvlak voor technologische ontwikkeling onder jongeren.

\section{De trechter naar techniek}

Willems en De Grip (1993) beschrijven de keuze voor de technische richting volgens het trechtermodel. Gedurende de schoolloopbaan vindt in het algemeen op drie plaatsen een vernauwing van de trechter plaats. Hierbij gaat het respectievelijk om de keuzes die leerlingen moeten maken ten aanzien van het schooltype na het basisonderwijs, het vakkenpakket en de vervolgopleiding. In figuur 7.1 is de trechter naar techniek weergeven. Aan de oorspronkelijke trechter is aan de onderkant een vierde vernauwing toegevoegd. De vernauwing treedt op doordat jongeren die een technische opleiding hebben gevolgd al direct bij arbeidsmarktintrede niet in een technisch beroep gaan werken (zie paragraaf 2.3).

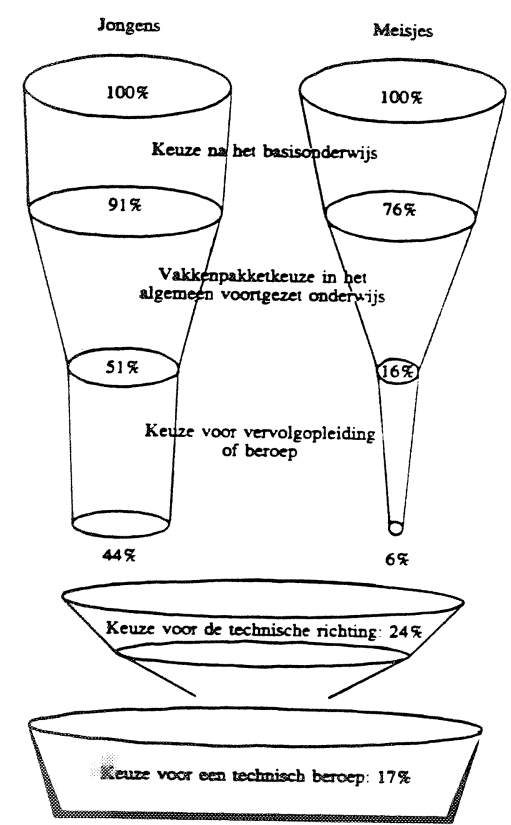


$\mathrm{Na}$ de drie keuzemomenten in het onderwijs zal totaal gezien slechts $24 \%$ van alle jongeren in de technische richting terecht komen. Daarbij kiest $44 \%$ van alle jongens en slechts $6 \%$ van de meisjes voor techniek. Van de technisch opgeleiden is echter ongeveer $70 \%$ werkzaam in een technisch beroep. Dit heeft tot gevolg dat, als de jongeren die bij het laatste keuzemoment aangeven dat ze verder willen in de techniek dit ook daadwerkelijk doen, uiteindelijk slechts $17 \%$ van alle jongeren in een technisch beroep werkzaam zal zijn.

De keuze voor de technische richting blijkt vooral samen te hangen met het geslacht en, niet verwonderlijk, de interesse in techniek in het algemeen. Daarnaast blijkt er een samenhang te bestaan met het beeld dat de jongeren van het technisch onderwijs en het werkveld van technisch opgeleiden hebben. Zo spelen de verwachtingen die leerlingen hebben ten aanzien van de kans op werk en de kans op het verdienen een relatief hoog inkomen een (geringe) rol. In het algemeen hebben jongeren hier overigens een gunstig beeld van, al moet worden opgemerkt dat jongens hier duidelijk positiever over ziijn dan meisjes (zie Willems en De Grip, 1993). Ook wanneer men de kans op zelfstandig werk voor technisch opgeleiden hoger inschat, kiest men iets vaker voor de technische richting.

In het rapport van Willems en De Grip wordt gepleit voor een 'brede aanpak', waarbij alle actoren hun steentje bijdragen aan het stimuleren van het technisch onderwijs. Gezien de scenarioresultaten die hier zijn gepresenteerd, is dit pleidooi nog steeds actueel. Vooral voor de hogere niveaus zijn maatregelen urgent. Op dit punt ligt zeker ook een verantwoordelijkheid voor de bouwsector. Willen zij niet in hun groeimogelijkheden worden geremd, zullen er meer studenten moeten kiezen voor een studie bouwkunde of civiele techniek op WO- en HBO-niveau. Juist het bedrijfsleven zal er zorg voor moeten dragen dat een dergelijke studie als een aantrekkelijker alternatief wordt gezien. 


\section{Literatuur}

Alessie, R., D. van Dongen, J.A.M. Helderman, A. Kersten, M.P. Pradhan, H. Senders, L.G.M. Spruit, H. Vermeulen, B. Werker (1992), Arbeidsmarktraming van leraren primair en voortgezet onderwijs; verbetering van de informatiebestanden en de ramingsmethodiek; deel II: voortgezet onderwijs, IVA, Tilburg.

Borghans, L., E.J.T.A. Willems (1994), Structuur en toekomstige ontwikkelingen op de arbeidsmarkt voor technici in de chemie en de metaal, ROA-W-1994/2, Maastricht.

Borghans, L., P. van Eijs, A. de Grip (1994), Evaluatie arbeidsmarktprognoses naar opleiding en beroep in 1992, ROA-R1994/4, Maastricht.

Centraal Bureau voor de Statistiek (1993), Standaard Beroepenclassificatie 1992, SDU-uitgeverij, Den Haag.

Centraal Bureau voor de Statistiek (1994), Kwartaalschrift Onderwijsstatistieken 1994-I, jrg. 1, nr. 1, Voorburg/Heerlen.

Centraal Planbureau (1993), Centraal Economisch Plan 1993, Den Haag.

Centraal Planbureau (1994), Macro Economische Verkenningen 1995, Den Haag.

Dekker, R.J.P., A. de Grip, L. Borghans, A.G.M. Matheeuwsen, M.H. Wieling, E.J.T.A. Willems (1993), Methodiek van het informatiesysteem onderwijs-arbeidsmarkt 1993, ROA-W-1993/3, Maastricht.

Grip, A. de, R. Dekker (1993), Winnaars en verliezers op de arbeidsmarkt 1985-1990, Tijdschrift voor Arbeidsvraagstukken, jrg. 9, nr. 3, blz. 220-229.

Grip, A. de, J.A.M. Heijke, R.J.P. Dekker (1989), De arbeidsmarkt naar opleiding en beroep in 1992, ROA-R-1989/8, Maastricht.

Grip, A. de, J.A.M. Heijke, E.J.T.A. Willems (1992), Scholing en mobiliteit, Maandschrift Economie, jrg. 59, blz. $131-144$.

Grip, A. de, P. Meijboom, E.J.T.A. Willems (1994), Vacancies, Employment Growth and the Demand for Newcomers on the Labour Market, ROA-R-1994/9, Maastricht.

Grip, A. de, R.K.W. van der Velden, M.H. Wieling (1993), De arbeidsmarktpositie van MDGO-schoolverlaters, Tijdschrift voor Arbeidsvraagstukken, jrg. 9, nr. 3, blz. 241-252.

Huijgen, F. (1989), De kwalitatieve structuur van de werkgelegenheid in Nederland, deel III, OSA-voorstudie V33, Den Haag.

Loo, P.J.E., van de, R.K.W. van der Velden, M.H. Wieling (1993), De arbeidsmarktpositie van afgestudeerden van het hoger beroepsonderwijs, HBO-Monitor 1992, landelijke rapportage, HBO-Raad, Den Haag.

Loo, P.J.E., van de, R.K.W. van der Velden (1994), De arbeidsmarktpositie van afgestudeerden van het hoger beroepson derwijs, HBO-Monitor 1993, HBO-Raad, Den Haag.

Matheeuwsen, A.G.M., W. Smits, E.J.T.A. Willems, J. Hoevenberg (1994), Opzet en methodiek arbeidsmarktprognoses technisch opgeleiden, ROA-W-1994/4, Maastricht.

Ministerie van Economische Zaken (1990), Economie met open grenzen, Tweede Kamer, vergaderjaar 1989-1990, 21.670, nrs. 1-2, Den Haag.

Ministerie van Onderwijs en Wetenschappen (1994), Referentieraming 1994, Zoetermeer.

Researchcentrum voor Onderwijs en Arbeidsmarkt (1992), De arbeidsmarkt naar opleiding en beroep tot 1994, ROA-R1992/1, Maastricht.

Researchcentrum voor Onderwijs en Arbeidsmarkt (1993), De arbeidsmarkt naar opleiding en beroep tot 1998, ROA-R1993/10, Maastricht.

Smoorenburg, M.S.M., van, R.K.W. van der Velden, P.J.E. van de Loo, M.H. Wieling (1994), Schoolverlaters op de arbeidsmarkt; de uitstroom en bestemming van het schooljaar 1991-1992, Stichting Landelijk Dienstverlenend Centrum voor Studie- en Beroepskeuzevoorlichting, Leeuwarden.

Wieling, M., L. Borghans, (1995), Discrepancies between demand and supply and adjustment processes on the labour market, Maastricht, verschijnt binnenkort.

Willems, E.J.T.A. (1993), De arbeidsmarkt voor technisch opgeleiden; haalbaarheidsonderzoek, ROA-R-1993/12, Maastricht.

Willems, E.J.T.A., A. de Grip (1993), Jongeren en techniek; Studie- en beroepskeuzes, waardering en beeldvorming ten aanzien van techniek, Beleidsstudies Technologie Economie nr. 26, Ministerie van Economische Zaken, Den Haag. 


\section{Bijlage A Opleidingsindeling technisch onderwijs}

Tabel A.1

Technische opleidingsniveaus en -richtingen

Wetenschappelijk onderwijs wiskunde en natuurwetenschappen bouwkunde/civiele techniek werktuigbouwkunde elektrotechniek/informatica overig

Hoger beroepsonderwijs technisch laboratorium bouwkunde/weg- en waterbouwkunde werktuigbouwkunde elektrotechniek/informatica overig

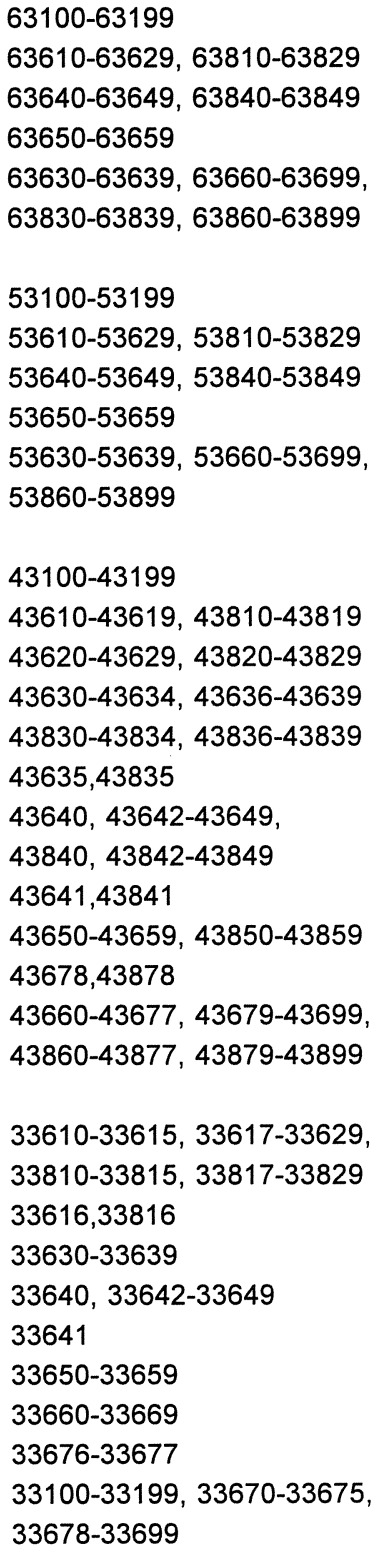

43100-43199

43610-43619, 43810-43819

43620-43629, 43820-43829

43630-43634, 43636-43639

43830-43834, 43836-43839

43635,43835

$43640,43642-43649$

$43840,43842-43849$

43641,43841

43650-43659, 43850-43859

43678,43878

43660-43677, 43679-43699,

43860-43877, 43879-43899

$33610-33615,33617-33629$,

33810-33815, 33817-33829

33616,33816

33630-33639

33640, 33642-33649

33641

33650-33659

33660-33669

33676-33677

33100-33199, 33670-33675

33678-33699

Voorbereidend beroepsonderwijs bouwtechniek (incl. weg-/waterbouwkunde)

installatietechniek

metaalkunde

werktuigbouwkunde

motorvoertuigentechniek

grafische techniek

consumptieve techniek 


\section{Bijlage B Aanvullende tabellen bij hoofdstuk 2}

Tabel B.1

Belangrijkste bedrijfssectoren voor technisch opgeleiden naar opleidingsniveau en -richting gemiddelde 1992-1993

\begin{tabular}{lll}
\hline Opleidingsniveau en -richting & bedrijfssector & aantal werkenden
\end{tabular}

Wetenschappelijk onderwijs

Wiskunde en natuurkunde

Technisch

bouwkunde/civiele techniek

werktuigbouwkunde

elektrotechniek/informatica

Hoger beroepsonderwijs

Technisch laboratorium

\section{Technisch}

bouwkunde/weg- en waterbouwkunde

werktuigbouwkunde

elektrotechniek/informatica

Middelbaar beroepsonderwijs

Technisch laboratorium

Technisch

bouwkunde

weg- en waterbouwkunde

metaalkunde

fijnmechanische techniek

werktuigbouwkunde overige commerciële dienstverlening

6.000

kwartaire diensten

6.000

openbaar bestuur, politie, defensie en onderwijs

16.000

overige commerciële diensten

10.000

openbaar bestuur, politie, defensie en onderwijs

5.000

metaal, elektrotechnische en transportmiddelenindustrie $\quad 3.000$

metaal, elektrotechnische en transportmiddelenindustrie $\quad 3.000$

openbaar bestuur, politie, defensie en onderwijs

3.000

chemie

overige commerciële dienstverlening

kwartaire diensten

openbaar bestuur, politie, defensie en onderwijs

5.000

3.000

6.000

5.000

bouw

8.000

overige commerciële dienstverlening

11.000

metaal, elektrotechnische en transportmiddelenindustrie 10.000

handel

overige commerciële dienstverlening

3.000

5.000

3.000

metaal elektrotechnische en transportmiddelenindustrie $\quad 12.000$

handel

overige commerciële dienstverlening

5.000

7.000

4.000

openbaar bestuur, politie, defensie en onderwijs

3.000

overige industrie

9.000

metaal, elektrotechnische en transportmiddelenindustrie $\quad 8.000$

energie

bouw

3.000

handel

88.000

10.000

4.000

vervoer en communicatie

overige commerciële dienstverlening

kwartaire diensten

12.000

4.000

8.000

7.000

3.000

bouw

6.000

openbaar bestuur, politie, defensie en onderwijs

metaal, elektrotechnische en transportmiddelenindustrie

bouw

34.000

4.000

5.000

3.000

3.000

3.000

overige commerciële dienstverlening

openbaar bestuur, politie, defensie en onderwijs

5.000

3.000

handel

3.000

3.000

5.000

overige industrie

30.000

4.000

9.000

8.000 
Tabel B.1 (vervolg)

Belangrijkste bedrijfssectoren voor technisch opgeleiden gemiddelde 1992-1993

\begin{tabular}{|c|c|c|}
\hline Opleidingsniveau en -richting & bedrijfssector & antal werkenden \\
\hline elektrotechniek & $\begin{array}{l}\text { vervoer en communicatie } \\
\text { overige commerciële dienstverlening } \\
\text { openbaar bestuur, politie, defensie en onderwijs } \\
\text { metaal, elektrotechnische en transportmiddelenindustrie } \\
\text { handel } \\
\text { vervoer en communicatie } \\
\text { overige commerciële dienstverlening } \\
\text { openbaar bestuur, politie, defensie en onderwijs } \\
\text { voedings- en genotmiddelenindustrie } \\
\text { overige industrie } \\
\text { chemie } \\
\text { metaal, elektrotechnische en transportmiddelenindustrie } \\
\text { energie } \\
\text { bouw } \\
\text { handel } \\
\text { vervoer en communicatie } \\
\text { overige commerciële dienstverlening } \\
\text { kwartaire diensten } \\
\text { openbaar bestuur, politie, defensie en onderwijs } \\
\text { chemie } \\
\text { metaal, elektrotechnische en transportmiddelenindustrie }\end{array}$ & $\begin{array}{r}6.000 \\
9.000 \\
4.000 \\
6.000 \\
13.000 \\
8.000 \\
26.000 \\
3.000 \\
4.000 \\
3.000 \\
5.000 \\
33.000 \\
8.000 \\
27.000 \\
23.000 \\
14.000 \\
12.000 \\
5.000 \\
7.000 \\
8.000 \\
3.000\end{array}$ \\
\hline Voorbereidend beroepsonderwijs & & \\
\hline $\begin{array}{l}\text { grafische techniek } \\
\text { consumptieve techniek }\end{array}$ & $\begin{array}{l}\text { landbouw, visserij en bosbouw } \\
\text { voedings- en genotmiddelenindustrie } \\
\text { overige industrie } \\
\text { chemie } \\
\text { metaal, elektrotechnische en transportmiddelenindustrie } \\
\text { bouw } \\
\text { handel } \\
\text { vervoer en communicatie } \\
\text { overige commerciële dienstverlening } \\
\text { kwartaire diensten } \\
\text { openbaar bestuur, politie, defensie en onderwijs } \\
\text { bouw } \\
\text { landbouw, visserij en bosbouw } \\
\text { voedings- en genotmiddelenindustrie } \\
\text { overige industrie } \\
\text { chemie } \\
\text { metaal, elektrotechnische en transportmiddelenindustrie } \\
\text { bouw } \\
\text { handel } \\
\text { vervoer en communicatie } \\
\text { overige commerciële dienstverlening } \\
\text { kwartaire diensten } \\
\text { openbaar bestuur, politie, defensie en onderwijs } \\
\text { metaal, elektrotechnische en transportmiddelenindustrie } \\
\text { bouw } \\
\text { handel } \\
\text { vervoer en communicatie } \\
\text { overige commerciële dienstverlening } \\
\text { openbaar bestuur, politie, defensie en onderwijs } \\
\text { overige industrie } \\
\text { metaal, elektrotechnische en transportmiddelenindustrie } \\
\text { bouw } \\
\text { handel } \\
\text { vervoer en communicatie } \\
\text { overige commerciële dienstverlening } \\
\text { openbaar bestuur, politie, defensie en onderwijs } \\
\text { overige industrie } \\
\text { voedings- en genotmiddelenindustrie } \\
\text { handel } \\
\text { overige commerciële dienstverlening }\end{array}$ & $\begin{array}{r}3.000 \\
3.000 \\
13.000 \\
3.000 \\
12.000 \\
60.000 \\
12.000 \\
10.000 \\
8.000 \\
4.000 \\
6.000 \\
5.000 \\
5.000 \\
5.000 \\
6.000 \\
4.000 \\
50.000 \\
16.000 \\
14.000 \\
14.000 \\
8.000 \\
3.000 \\
7.000 \\
6.000 \\
4.000 \\
6.000 \\
7.000 \\
10.000 \\
3.000 \\
3.000 \\
13.000 \\
13.000 \\
8.000 \\
7.000 \\
5.000 \\
4.000 \\
4.000 \\
7.000 \\
5.000 \\
3.000\end{array}$ \\
\hline
\end{tabular}

Bron: CBS/ROA 
Tabel B.2

Belangrijkste beroepsklassen ${ }^{*}$ voor technisch opgeleiden naar opleidingsniveau en -richting gemiddelde 1992-1993

Opleidingsniveau en -richting

beroepsklasse

aantal werkenden

Wetenschappelijk onderwijs

Wiskunde en natuurkunde

docenten voortgezet en hoger onderwijs $\quad 10.000$

bèta-onderzoekers en technische vakspecialisten $\quad 9.000$

systeemanalisten, -programmeurs en -beheerders $\quad 4.000$

Technisch

bouwkunde/civiele techniek

werktuigbouwkunde

elektrotechniek/informatica

architecten, geodeten e.a. hogere bouwkundigen

9.000

hogere elektrotechnici

3.000

systeemanalisten, -programmeurs en -beheerders

3.000

Hoger beroepsonderwijs

Technisch laboratorium

7.000

bèta-onderzoekers en technische vakspecialisten $\quad 3.000$

Technisch

bouwkunde/weg- en waterbouwkunde

leidinggevenden bouw en industrie

8.000

technische tekenaars

bouwkundige technici, opzichters en werkvoorbereiders $\quad 4.000$

architecten, geodeten e.a. hogere bouwkundigen $\quad 10.000$

werktuigbouwkunde

leidinggevenden bouw en industrie

9.000

hogere werktuigbouwkundigen $\quad 3.000$

leidinggevenden bouw en industrie $\quad 5.000$

hogere elektrotechnici 7.000

systeemanalisten, -programmeurs en -beheerders $\quad 11.000$

Middelbaar beroepsonderwijs

Technisch laboratorium

technische analisten en amanuenses

Technisch

bouwkunde

leidinggevenden bouw en industrie

21.000

technische tekenaars

5.000

timmerlieden e.a. houtbewerkers

38.000

metselaars, tegelzetters, straatmakers en stukadoors $\quad 8.000$

huis-, scheeps- en constructieschilders 12.000

loodgieters, sanitair-installateurs en -reparateurs $\quad 12.000$

bouwkundige technici, opzichters en werkvoorbereiders $\quad 9.000$

architecten, geodeten e.a. hogere bouwkundigen $\quad 6.000$

chauffeurs en spoorwegpersoneel 3.000

commercieel-administratieve employees $\quad 3.000$

winkeliers e.a. detail- en groothandelaren 3.000

leidinggevenden bouw en industrie 4.000

bouwkundige technici, opzichters en werkvoorbereiders $\quad 4.000$

leidinggevenden bouw en industrie $\quad 6.000$

machinale metaalbewerkers $\quad 3.000$

lassers, constructiewerkers en edelmetaalsmeden $\quad 11.000$

machinebank-, plaatwerkers en gereedschapsmakers $\quad 14.000$

onderhoudsmonteurs, fietsen- en instrumentmakers $\quad 6.000$

fijnmechanische techniek werktuigbouwkunde

machinisten bouw en industrie $\quad 5.000$

leidinggevenden bouw en industrie $\quad 13.000$

technische tekenaars $\quad 6.000$

lassers, constructiewerkers en edelmetaalsmeden $\quad 3.000$

machinebank-, plaatwerkers en gereedschapsmakers $\quad 6.000$

onderhoudsmonteurs, fietsen- en instrumentmakers $\quad 12.000$

hogere werktuigbouwkundigen $\quad 3.000$

commercieel-administratieve employees $\quad 3.000$

in-/verkoopchefs, handels- en

verzekeringsagenten, makelaars e.d. $\quad 3.000$

leidinggevenden bouw en industrie $\quad 8.000$

machinebank-, plaatwerkers en gereedschapsmakers $\quad 4.000$

onderhoudsmonteurs, fietsen- en instrumentmakers $\quad 4.000$ 
Tabel B.2 (vervolg)

Belangrijkste beroepsklassen voor technisch opgeleiden gemiddelde 1992-1993

elektrotechniek

procestechniek

Voorbereidend beroepsonderwijs

\section{Technisch}

bouwtechniek

installatietechniek

metaalkunde

werktuigbouwkunde

motorvoertuigentechniek

elektrotechniek

grafische techniek consumptieve techniek automonteurs en (motor)rijwielherstellers

chauffeurs en spoorwegpersoneel

19.000

winkeliers e.a. detail- en groothandelaren

5.000

3.000

leidinggevenden bouw en industrie

17.000

technische tekenaars

4.000

machinebank-, plaatwerkers en gereedschapsmakers 6.000

onderhoudsmonteurs, fietsen- en instrumentmakers $\quad 8.000$

elektriciens, elektro- en telecom-

(onderhouds)monteurs

hogere elektrotechnici

8.000

50.000

5.000

3.000

6.000

$\begin{array}{ll}\text { winkel-, straat- en marktverkopers, demonstrateurs } & 3.000 \\ \text { winkeliers e.a. detail- en groothandelaren } & 3.000\end{array}$

$\begin{array}{ll}\text { winkel-, straat- en marktverkopers, demonstrateurs } & 3.000 \\ \text { winkeliers e.a. detail- en groothandelaren } & 3.000\end{array}$

in-/verkoopchefs, handels- en

verzekeringsagenten, makelaars e.d.

3.000

produktiepersoneel chemische industrie agrarisch personeel, bosarbeiders $\quad 3.000$

leidinggevenden bouw en industrie $\quad 6.000$

timmerlieden e.a. houtbewerkers 39.000

produktiepersoneel bouwmaterialen-,

glas- en aardewerkindustrie

$\begin{array}{lr}\text { metselaars, tegelzetters, straatmakers en stukadoors } & 14.000 \\ \text { betonwerkers, dakdekkers, isoleerders en glaszetters } & 4.000\end{array}$

huis-, scheeps- en constructieschilders $\quad 10.000$

overige bouwvak-, wegenbouw- en

reinigingswerkers $\quad 7.000$

expeditiemedewerkers, vul- en inpak(machine)bedienden $\quad 5.000$

chauffeurs en spoorwegpersoneel $\quad 8.000$

portiers, schoonmaak-, e.a. lager

dienstverlenend personeel $\quad 3.000$

loodgieters, sanitair-installateurs en -reparateurs $\quad 4.000$

agrarisch personeel, bosarbeiders $\quad 3.000$

machinisten bouw en industrie $\quad 3.000$

leidinggevenden bouw en industrie $\quad 8.000$

timmerlieden e.a. houtbewerkers $\quad 3.000$

machinale metaalbewerkers $\quad 7.000$

lassers, constructiewerkers en edelsmeden $\quad 21.000$

machinebank-, plaatwerkers en gereedschapsmakers $\quad 14.000$

onderhoudsmonteurs, fietsen- en instrumentmakers $\quad 9.000$

elektriciens, elektro- en telecom-

(onderhouds)monteurs

loodgieters, sanitair-installateurs en -reparateurs $\quad 6.000$

overige bouwvak-, wegenbouw- en

reinigingswerkers

produktiepersoneel bouwmaterialen-, glas- en
aardewerkindustrie

expeditiemedewerkers, vul- en inpak(machine)bedienden $\quad 5.000$

chauffeurs en spoorwegpersoneel 10.000

commercieel-administratieve employees $\quad 3.000$

automonteurs en (motor)rijwielherstellers $\quad 8.000$

chauffeurs en spoorwegpersoneel $\quad 7.000$

leidinggevenden bouw en industrie $\quad 3.000$

$\begin{array}{ll}\text { elektriciens, elektro- en telecom- } & 17.000 \\ \text { (onderhouds)monteurs } & \end{array}$

expeditiemedewerkers, vul- en inpak(machine)bedienden $\quad 3.000$

drukkers en produktiepersoneel grafische industrie $\quad 4.000$

bakkers e.a. (industrieel) bakkerijpersoneel $\quad 5.000$

koks, kelners e.a. keuken- en serveerpersoneel 3.000

tenminste 3.000 werkenden

Bron:CBS/ROA 


\section{Bijlage C Technische beroepsklassen}

Tabel C.1

Technische beroepsklassen in het ROA-informatiesysteem onderwijs-arbeidsmarkt

ROA- Beroepsklassenaam

code

3011 heftruck- en hefvorkchauffeurs

3012 machinisten bouw en industrie

3021 leidinggevenden produktie, bedrijfskundigen en directeuren

3022 technische en medische vertegenwoordigers

3023 technische tekenaars

3024 technische analisten en amanuenses

3031 bèta-onderzoekers en technische vakspecialisten

3111 voedings- en genotmiddelenbereiders

3112 bakkers en (industrieel) bakkerijpersoneel

3211 produktiepersoneel textielindustrie

3212 stoffeerders, schoen- en lederwarenmakers

3213 kleding- e.a. textielproduktenmakers

3311 houtwaren-, papier- en kartonmakers

3312 timmerlieden e.a. houtbewerkers

3411 drukkers en produktiepersoneel grafische industrie

3511 produktiepersoneel chemische industrie

3611 delfstoffen(be)werkers, metaalvervaardigers

3612 machinale metaalbewerkers

3613 lassers en constructiewerkers

3614 machinebank-, plaatwerkers en gereedschapsmakers

3615 onderhoudsmonteurs, fietsen- en instrumentmakers

3621 automonteurs en (motor)rijwielherstellers

3622 middelbare (scheeps)werktuig(bouw)kundigen

3631 hogere werktuigkundigen

3711 monteurs en controleurs van elektrotechnische produkten

3721 elektriciens, elektro- en telecom(onderhouds)monteurs

3731 hogere elektrotechnici

3811 produktiepersoneel bouwmaterialen-, glas- en aardewerkindustrie

3911 metselaars, tegelzetters, straatmakers en stukadoors

3912 betonwerkers, dakdekkers, isoleerders en glaszetters

3913 huis- en constructieschilders

3914 loodgieters, pijpfitters en verwarmingsmonteurs

3915 gespecialiseerde bouwvak-, wegenbouw- en reinigingswerkers

3921 bouwkundige technici, opzichters en werkvoorbereiders

3931 architecten, geodeten e.a. hogere bouwkundigen 
OPLEIDINGSFICHES 


\section{WO Wiskunde en natuurwetenschappen}

De werkgelegenheid voor opgeleiden in de wiskunde en natuurwetenschappen bedraagt momenteel bijna 40.000 personen, ruim $2 \frac{1}{2} \%$ van de totale werkgelegenheid voor technisch opgeleiden in Nederland. Vergeleken met de andere technisch opleidingen is het percentage vrouwen en het percentage deeltijdwerkers bij deze opleiding hoog (beide 16\%) en is een groot deel van de werkenden tussen de 30 en 40 jaar. De overheidssector is voor deze opleiding het belangrijkste. Ruim $40 \%$ van de werkenden heeft een baan in deze sector. Zij zijn vooral werkzaam in de beroepsklassen docenten voortgezet en hoger onderwijs (26\%) en bètaonderzoekers en technische vakspecialisten $(24 \%)$.

De werkgelegenheid voor WO wiskunde en natuurwetenschappen is niet conjunctuurgevoelig, mede door de sterke afhankelijkheid van de overheidssector en daarbinnen met name het onderwijs. Dit betekent overigens wel dat de uitwijkmogelijkheden naar andere bedrijfssectoren niet erg groot zijn. Overigens zijn zij ook niet erg laag te noemen. De uitwijkmogelijkheden naar andere beroepen zijn zelfs redelijk groot. Helaas zijn voor deze opleiding geen gegevens beschikbaar over de huidige marktpositie van de recent afgestudeerden.

Voor de periode tot 2000 is het arbeidsmarktperspectief voor schoolverlaters uitgesproken gunstig te noemen. Zowel de uitbreidingsvraag als de vervangingsvraag is de komende jaren zo'n $2 \frac{1}{2} \%$ per jaar. Samen betekent dit een totale vraag naar nieuwkomers van bijna 14.000 in de periode 1993-2000. Verwacht wordt dat de arbeidsmarktinstroom vanuit het onderwijs hieraan niet kan voldoen. Om een evenwichtige arbeidsmarktsituatie te verkrijgen zouden er 500 tot 1.000 mensen meer voor een dergelijke opleiding moeten kiezen, hetgeen overeenkomt met $6 \%$ tot $12 \%$ van de huidige instroom van schoolverlaters op de arbeidsmarkt.

Verwacht mag derhalve worden dat werkgevers de komende jaren problemen zullen ondervinden bij de werving van personeel met een opleiding in de wiskunde of natuurwetenschappen, zelfs bij een gematigde groei van de economie. Bij een gunstige economische ontwikkeling zullen de problemen alleen maar groter worden. Ook een verlaging van de uitstroom, door beperking van VUT en WAO, kunnen er niet voor zorgen dat de arbeidsmarkt voor deze opleiding in voldoende mate wordt verlicht. Vanwege de lange opleidingstijd levert ook een hogere doorstroom in het onderwijs naar deze opleiding voor het jaar 2000 onvoldoende resultaat op. 


\section{WO bouwkunde/civiele techniek}

Bijna 20.000 werkenden hebben een academische opleiding in de bouwkunde of civiele techniek, voor het overgrote merendeel mannen. De gemiddelde leeftijd is bij deze opleiding erg hoog: maar liefst bijna $60 \%$ van de werkenden is ouder van 40 jaar, waarvan meer dan 20\%-punt ouder dan 50 . Ongeveer de helft van de arbeidskrachten is werkzaam in de commerciële dienstverlening. Daarnaast is de overheidssector vrij belangrijk: ruim een kwart van de werkenden heeft een baan in deze sector.

De opleiding WO bouwkunde/civiele techniek is slechts gericht op een beperkt aantal segmenten van de arbeidsmarkt. Zowel met betrekking tot de bedrijfsklassen als de beroepsgroepen zijn de uitwijkmogelijkheden gering. De werkgelegenheid voor deze opleidingscategorie is echter, zeker in vergelijking met de andere technische opleidingen, niet conjunctuurgevoelig. Over deze opleidingen zijn helaas geen gegevens beschikbaar over de arbeidsmarktpositie van de recent afgestudeerden.

Voor de komende jaren wordt voor deze opleiding een forse uitbreidingsvraag verwacht: ruim 5.000 arbeidsplaatsen komen er bij, overeenkomend met een gemiddelde jaarlijkse groei van $3,6 \%$. De vervangingsvraag is zelfs met bijna 6.000 personen nog hoger. Dit hangt vooral ook samen met de reeds genoemde hoge gemiddelde leeftijd bij deze opleiding. Al met al betekent dit er tot het jaar 2000 een grote behoefte aan nieuwkomers op de arbeidsmarkt is.

De arbeidsmarktinstroom van schoolverlaters is daarentegen de komende jaren naar verwachting vrij laag. Dit is overigens mede het gevolg van de numerus fixus op de bouwkunde-opleidingen in Delft en Eindhoven. De jaarlijkse instroom op de arbeidsmarkt bedraagt, uitgedrukt in procenten van het aantal werkenden, slechts $2,4 \%$. Dit leidt tot een groot tekort dat zelfs kan oplopen tot bijna 3.000 nieuwkomers. In procenten van de verwachte instroom van schoolverlaters is dat maar liefst ruim $80 \%$.

De kans dat werkgevers de komende jaren knelpunten gaan ondervinden bij het werven van bouwkundigen en civiel technisch ingenieurs is dus bijzonder groot. Daar tegenover staat dat de toekomstige afgestudeerden in deze richting een erg gunstige positie op de arbeidsmarkt zullen hebben. Zelfs een forse afname van de arbeidsmarktuitstroom van ouderen of een grotere doorstroom naar de technische opleidingen zal in dit beeld voorlopig geen verandering kunnen brengen. 


\section{WO werktuigbouwkunde}

Ongeveer een derde van de circa 9.000, vrijwel allemaal mannelijke, arbeidskrachten met een opleiding WO werktuigbouwkunde werkt in de bedrijfssector metaal, elektrotechnische en transportmiddelenindustrie. Voor het overige zijn de werkenden echter over vrij veel bedrijfsklassen gespreid. Dit betekent derhalve dat de uitwijkmogelijkheden naar andere bedrijfsklassen voor werktuigbouwkundigen, zeker in vergelijking met de andere hogere technische opleidingen, groot zijn. De uitwijkmogelijkheden naar andere beroepsgroepen op aansluitend of hoger functieniveau zijn niet groot en niet klein te noemen. De werkgelegenheid voor deze opleiding is ook niet bijzonder conjunctuurgevoelig. Momenteel is helaas nauwelijks informatie beschikbaar over de actuele arbeidsmarktpositie van de recent afgestudeerde werktuigbouwkundigen.

Voor de komende jaren wordt een gunstig arbeidsmarktperspectief verwacht. Dit komt vooral ook omdat de afgestudeerden van deze opleiding zullen meeprofiteren van de krappe arbeidsmarkt die voor bouwkundigen en civiel technisch ingenieurs zal ontstaan. De uitbreidingsvraag en de vervangingsvraag zijn voor deze opleiding beide relatief hoog: respectievelijk $3,6 \%$ en $3,5 \%$ gemiddeld per jaar. Ook de arbeidsmarktinstroom vanuit het onderwijs is echter groot, relatief gezien het hoogste van alle technische opleidingen (5,9\% per jaar). Dit zou een redelijk evenwichtige arbeidsmarkt betekenen, ware het niet dat, zoals gezegd, door het tekort aan bouwkundigen e.d. een extra vraagimpuls ontstaat.

Werkgevers zullen dus naar verwachting te maken krijgen met problemen ten aanzien van de werving van de werving van werktuigbouwkundigen. Alleen bij een forse toename van de doorstroom naar het hoger technisch onderwijs (zowel vanuit het WWO als een grotere doorstroom van het HBO technisch naar het WO technisch) kan deze problematiek iets worden verlicht. Een beperking van de uitstroom van arbeidskrachten naar WAO of VUT zet nauwelijks zoden aan de dijk: de kans op knelpunten bij de personeelsvoorziening blijft groot. Vanzelfsprekend wordt dit alleen nog maar erger bij een gunstigere economische ontwikkeling dan waarvan in het basisscenario wordt uitgegaan. 


\section{WO elektrotechniek/informatica}

De totale werkgelegenheid voor de opleiding WO elektrotechniek/informatica bedraagt momenteel 11.000 personen, ofwel $0,8 \%$ van de totale werkgelegenheid voor technisch opgeleiden in Nederland. Dit zijn vrijwel allemaal mannen. Opvallend in vergelijking met de andere wetenschappelijke technische opleidingen is de gemiddelde leeftijd. Bijna $65 \%$ is jonger dan 40 jaar, terwijl het percentage $50^{+1}$ ers erg klein is. De twee belangrijkste beroepsklassen voor deze opleiding zijn hogere elektrotechnici en systeemanalisten, -programmeurs en -beheerders, beide met een werkgelegenheidsaandeel van ruim $25 \%$. De belangrijkste bedrijfssectoren zijn de metalektro en de overheidssector (beide $27 \%$ ).

De conjunctuurgevoeligheid van de werkgelegenheid voor deze opleiding is niet erg groot. Ook de uitwijkmogelijkheden naar andere bedrijfsklassen zijn niet groot en niet klein te noemen. Hetzelfde geldt voor het arbeidsmarktbereik wat betreft de beroepsklassen op aansluitend of hoger functieniveau. Op dit moment zijn er helaas geen gegevens beschikbaar over de actuele arbeidsmarktpositie van recent afgestudeerden in deze richting.

De uitbreidingsvraag voor deze opleiding is de komende jaren naar verwachting relatief groot $(3,3 \%$ gemiddeld per jaar), ofschoon iets lager dan voor de WO-opleidingen bouwkunde/civiele techniek en werktuigbouwkunde. Opvallend is echter de fors lagere vervangingsvraag, uiteraard samenhangend met de reeds genoemde lage gemiddelde leeftijd van de werkenden. Al met al resulteert dit in ruim 5.500 baanopeningen voor nieuwkomers in de periode $1993-2000$.

De arbeidsmarktinstroom van schoolverlaters bedraagt eveneens circa 5.500 personen, zodat gesproken zou kunnen worden van een vrij evenwichtige arbeidsmarkt. Toch is er een grote kans dat werkgevers in de nabije toekomst problemen zullen ondervinden bij de werving van nieuw personeel met een dergelijke opleidingsachtergrond. Dit komt met name ook omdat er een opwaartse druk op de vraag ontstaat vanwege de tekorten bij de andere hogere technische opleidingen. De perspectieven voor schoolverlaters kunnen derhalve als gunstig worden getypeerd.

Bij een gunstigere economische ontwikkeling dan in het basisscenario voorzien zal dit beeld alleen maar versterkt worden. Maatregelen als het beperken van de instroom in de WAO en de toegang tot de VUT hebben nauwelijks effect op de verwachte arbeidsmarktsituatie. Door de lage gemiddelde leeftijd in deze opleiding wordt momenteel reeds relatief weinig van deze regelingen gebruik gemaakt.

Een grotere doorstroom naar de opleidingen in het WO technisch, zowel vanuit WWO als vooral ook HBO technisch, heeft wel enige invloed op de toekomstige arbeidsmarktsituatie. Werkgevers zullen een iets minder moeite hebben bij de werving van nieuw personeel. De perspectieven voor schoolverlaters op de arbeidsmarkt worden hierdoor iets minder gunstig. De perspectieven worden in dit geval als redelijk getypeerd. 


\section{HBO technisch laboratorium}

Er zijn in totaal circa 27.000 werkenden met een opleiding HBO technisch laboratorium. De man/vrouwverhouding is ongeveer 7:3. In vergelijking met de andere technische opleidingen betekent dit een hoog percentage vrouwen. Ook het percentage deeltijdwerkers is hoog: $15 \%$. De belangrijkste bedrijfssectoren voor deze opleiding zijn de kwartaire diensten ( $22 \%$ van de werkenden), de chemische industrie en de overheidssector (beide bijna 20\%). Ruim een kwart van de arbeidskrachten is werkzaam in de beroepsklasse technische analisten en amanuenses. Daarnaast zijn de beroepsklassen radiologische, medische en biologische laboranten (15\%) en bèta-onderzoekers en technische vakspecialisten (11\%) belangrijk voor deze opleiding.

Zoals hierboven reeds blijkt, zijn de werkenden met deze opleidingsachtergrond niet sterk afhankelijk van één of enkele bedrijfsklassen. De uitwijkmogelijkheden naar verschillende bedrijfsklassen zijn derhalve, zeker in vergelijking met de andere hogere technische opleidingen, groot. De uitwijkmogelijkheden naar andere beroepsgroepen kunnen als gemiddeld worden getypeerd. Verder is de werkgelegenheid voor deze opleidingscategorie niet erg conjunctuurgevoelig.

Van de afgestudeerden van het schooljaar 1991-1992 heeft 90\% binnen 3 maanden een baan gevonden. Zo'n anderhalf jaar na afstuderen is $13 \%$ van de recent afgestudeerden (opnieuw) werkloos. Dit is ongeveer gelijk aan het gemiddelde voor alle HBO-opleidingen, maar relatief laag in vergelijking met de andere technische opleidingen. De mate van onderbenutting is relatief laag. Al met al kan dus van een vrij gunstige arbeidsmarktpositie worden gesproken. Daarbij kan wel worden aangetekend dat het gemiddelde bruto uurloon voor deze opleiding aan de lage kant. Per maand komt dit neer op ruim 100 gulden minder ten opzichte van de andere techische opleidingen in het HBO. Verder zijn de uitwijkmogelijkheden voor recent afgestudeerden naar andere beroepsgroepen relatief gering. De arbeidsmarktflexibiliteit ten aanzien van de verschillende bedrijfssectoren alsmede de conjunctuurgevoeligheid kunnen als gemiddeld worden aangemerkt. Ten slotte vindt ruim een kwart van de afgestudeerden dat in de opleiding meer aandacht zou moeten worden besteed aan informatica/ automatisering en het omgaan met apparatuur of materialen. In vergelijking met de andere technische HBO-opleidingen zijn deze percentages zeker niet hoog.

Voor de komende jaren is het arbeidsmarktperspectief voor deze opleiding goed te noemen. De vervangingsvraag is weliswaar laag, maar er wordt een redelijke groei van de werkgelegenheid verwacht. Het totaal aantal baanopeningen in de periode $1993-2000$ is ruim 8.000 , ofwel $4 \%$ gemiddeld per jaar. De arbeidsmarktinstroom vanuit het onderwijs is naar verwachting onvoldoende om aan deze vraag te voldoen. $\mathrm{Er}$ ontstaat een tekort aan enkele honderden nieuwkomers op de arbeidsmarkt.

Werkgevers zullen derhalve moeilijkheden ondervinden bij het werven van nieuwe arbeidskrachten, een situatie die alleen maar toeneemt wanneer de economische ontwikkeling gunstiger is dan in het basisscenario is voorzien. Ook een vermindering van de arbeidsmarktuitstroom vanwege WAO of VUT, alsmede een hogere doorstroom van het MBO naar het HBO neemt de problemen niet weg. De toekomstige afgestudeerden houden derhalve ook in deze scenario's een gunstige positie op de arbeidsmarkt. 
In totaal werken er in Nederland momenteel ongeveer 33.000 mensen met een opleiding HBO bouwkunde/weg- en waterbouwkunde. Dat is $2,3 \%$ van het totaal aantal werkenden met een technische opleiding. Ongeveer één op de drie arbeidskrachten met deze opleiding is werkzaam in de overige commerciële dienstverlening, $27 \%$ werkt bij de overheid en $24 \%$ in de bouwsector. Zij zijn met name werkzaam in de beroepsklassen architecten, geodeten en andere hogere bouwkundigen (30\%), leidinggevenden bouw en industrie (24\%), bouwkundig technici, opzichters en werkvoorbereiders (12\%) en technische tekenaars (9\%). Het percentage vrouwen is zeer laag; $97 \%$ van alle werkenden met deze opleidingsachtergrond is man. Verder zijn de werkenden met deze opleidingsachtergrond relatief oud: meer dan de helft is 40 jaar of ouder.

De werkgelegenheid voor deze opleiding is niet bijzonder conjunctuurgevoelig. De uitwijkmogelijkheden naar beroepen op een aansluitend of hoger functie niveau zijn echter niet zo groot. Voor schoolverlaters zijn deze uitwijkmogelijkheden zelfs klein. De uitwijkmogelijkheden naar andere bedrijfsklassen zijn voor schoolverlaters eveneens klein. Toch hebben momenteel recent afgestudeerden een goede arbeidsmarktpositie, hetgeen onder meer blijkt uit de in vergelijking met de andere HBO-opleidingen lage werkloosheid onder schoolverlaters: ongeveer $10 \%$ van deze schoolverlaters is werkloos. Ook de duur van de intredewerkloosheid is relatief laag. Ruim $70 \%$ vindt meteen een baan. Een kwart van de pas afgestudeerden zoekt 1 tot 3 maanden en slechts $6 \%$ zoekt langer dan 4 maanden. Werkenden met een opleiding HBO bouwkunde/weg- en waterbouwkunde werken bovendien niet vaak onder hun niveau. Slechts een beperkt deel van de schoolverlaters is in een niet-technisch beroep werkzaam. Dit duidt eveneens op een goede arbeidsmarktpositie voor schoolverlaters uit deze opleiding. Zij hoeven geen baan onder hun niveau te accepteren of uit te wijken naar andere niet-technische beroepen. Een andere indicatie van de momenteel goede arbeidsmarktpositie voor schoolverlaters is het feit dat zij het hoogste gemiddeld bruto uurloon hebben van alle technisch opgeleiden op HBO-niveau. Wel blijkt dat de pas afgestudeerden relatief vaak vinden dat er tijdens de opleiding te weinig aandacht werd besteed aan vakkennis, informatica/automatisering en het omgaan met apparatuur en materialen. Zij zijn dus blijkbaar niet altijd optimaal toegerust op de functies die zij bekleden.

Deze gunstige arbeidsmarktsituatie voor schoolverlaters zal naar verwachting ook in de komende jaren nog voortduren. De verwachte uitbreidingsvraag en vooral ook de vervangingsvraag zijn relatief hoog. Het totaal aantal baanopeningen bedraagt voor de periode tot het jaar 2000 naar verwachting ruim 14.000. Dat komt neer op jaarlijks $5,1 \%$ van het totaal aantal werkenden. De verwachte arbeids-marktinstroom is daarentegen relatief laag. De totale instroom zal naar verwachting jaarlijks $2,2 \%$ van het totaal aantal werkenden bedragen. Als gevolg van deze lage instroom zal er een tekort aan schoolverlaters ontstaan dat ongeveer tussen de 1.500 en 3.000 zal liggen. Dat betekent dat de totale instroom met zo'n $30 \%$ tot $60 \%$ moet toenemen om een evenwichtige arbeidsmarkt te bereiken.

De arbeidsmarktperspectieven voor HBO bouwkunde/weg- en waterbouwkunde zijn derhalve goed. Dit betekent echter tevens dat voor de werkgeverd de kans op knelpunten bij de personeelsvoorziening vrij groot is. Met name de bouwsector, de overige commerciële dienstverlening en de overheidssector zullen hiervan de meeste hinder ondervinden. Als de economische ontwikkelingen gunstiger zijn dan in het basisscenario is verondersteld, neemt de kans op knelpunten nog meer toe. Een eventuele afname van de vervangingsvraag, bijvoorbeeld door een geringe uitstroom als gevolg van arbeidsongeschiktheid zal hier weinig invloed op hebben. Ook een grotere doorstroom van het MBO technisch naar het HBO technisch zal deze knelpunten maar nauwelijks kunnen oplossen. Daarvoor is het tevens noodzakelijk dat een groter deel van de studenten voor de richting bouwkunde/weg- en waterbouwkunde kiest. 


\section{HBO werktuigbouwkunde}

Circa 30.000 werkenden hebben HBO werktuigbouwkunde als opleidingsachtergrond. Dit zijn vrijwel allemaal mannen. Ruim $50 \%$ is jonger dan 40 jaar, ongeveer overeenkomend met het gemiddelde voor de technische opleidingen op HBO-niveau. Circa $30 \%$ van de arbeidskrachten is werkzaam in de beroepsklasse leidinggevenden bouw en industrie. Daarnaast is vooral ook de beroepsklasse hogere werktuigbouwkundigen belangrijk (10\% van de werkgelegenheid).

De uitwijkmogelijkheden naar andere bedrijfsklassen zijn voor deze opleiding relatief groot. Ook zijn er in vergelijking met andere opleidingen relatief veel mogelijkheden om uit te wijken naar andere beroepen op aansluitend of hoger functieniveau. De werkgelegenheid voor werktuigbouwkundigen op HBO-niveau is niet erg conjunctuurgevoelig. Eenzelfde beeld geldt ook voor de recent afgestudeerden in deze richting. Wel hebben zij in het algemeen wat minder mogelijkheden om uit te wijken naar andere beroepen. De uitwijkmogelijkheden met betrekking tot de bedrijfsklassen zijn echter ook voor recent afgestudeerden groot te noemen. Toch is maar liefst $22 \%$ van de recent afgestudeerden circa $1 \frac{1}{2}$ jaar na afstuderen werkloos. Velen hebben overigens wel tussentijds reeds een baantje gehad, maar bijna $15 \%$ is in totaal meer dan 4 maanden werkloos geweest. Deze wat zwakkere arbeidsmarktpositie van dit moment komt ook naar voren in de mate van onderbenutting (24\%). Ook het gemiddeld bruto inkomen is wat lager dan bij de andere technische opleidingen op HBOniveau. Het verschil bedraagt circa 100 gulden bruto per maand. De recent afgestudeerden zijn wel tevreden over de vakkennis die zij in hun opleiding hebben verkregen; dit vormt nauwelijks een belemmering op de arbeidsmarkt. Wel had men graag gezien dat er wat meer aandacht zou worden besteed aan informatica/automatisering en het omgaan met apparatuur en materialen.

Ondanks de huidige sombere berichten wordt voor de nabije toekomst een gunstig arbeidsmarktperspectief voorzien. Vooral de uitbreidingsvraag is relatief hoog: $2,2 \%$ gemiddeld per jaar. De vervangingsvraag blijt iets achter bij de andere technische HBO-opleidingen en de instroom van schoolverlaters is naar verwachting iets hoger dan het gemiddelde. De toekomstige afgestudeerden in deze richting zullen echter vooral ook profiteren van de vraag die ontstaat vanwege het verwachte tekort aan (weg- en water)bouwkundigen op HBO-niveau.

De werkgevers zullen derhalve moeilijkheden ondervinden bij het aantrekken van nieuw personeel. Vooral in de metalektro zal dit het geval zijn. Maatregelen ter beperking van de instroom in de WAO, alsmede het terugdringen van de deelname aan de VUT-regelingen zullen voor deze opleidingen weinig soelaas bieden. Wel kan een grotere doorstroom vanuit het MBO technisch naar het HBO technisch de spanningen op de arbeidsmarkt enigszins verlichten. De perspectieven voor schoolverlaters met deze opleidingen zijn echter ook in dat geval nog redelijk. 
Momenteel zijn er een kleine 40.000 werkenden met een opleiding HBO elektrotechniek of informatica, overigens vrijwel allemaal mannen. Opvallend bij deze opleiding is de relatief lage gemiddelde leeftijd. Zo is slechts $13 \%$ van de werkenden 50 jaar of ouder, terwijl dit bij de overige technische HBO-opleidingen bijna $20 \%$ is. Ongeveer $30 \%$ van de arbeidskrachten is werkzaam in de metaal, elektrotechnische of transportmiddelenindustrie, maar ook de sectoren overige commerciële dienstverlening (18\%), handel (13\%) en openbaar bestuur, politie, defensie en onderwijs (10\%) zijn belangrijk. Ruim een kwart is werkzaam in de beroepsklasse systeemanalisten, -programmeurs en -beheerders. Verder heeft een substantieel deel van de werkenden een baan in de beroepsklasse hogere elektrotechnici (18\%) of leidinggevenden bouw en industrie $(13 \%)$.

Deze opleiding is niet bijzonder gevoelig voor conjuncturele schommelingen in de werkgelegenheid. Verder kunnen ook de uitwijkmogelijkheden naar beroepen op aansluitend of hoger functieniveau, alsmede de uitwijkmogelijkheden naar andere bedrijfssectoren als gemiddeld worden getypeerd. Jongeren lijken in wat meer bedrijfstakken inzetbaar te zijn. Opvallend is echter dat de uitwijkmogelijkheden van recent afgestudeerden naar andere beroepsgroepen juist gering zijn. Dit is er wellicht mede de oorzaak van dat de werkloosheid onder recent afgestudeerden van deze opleiding erg hoog is: $26 \%$. Slechts $40 \%$ is in aansluiting op de opleiding niet werkloos geweest, een in vergelijking met de andere opleidingen erg laag percentage. Ook het percentage onderbenutting is aan de hoge kant. Het bruto inkomen verschilt daarentegen nauwelijks van de andere technische HBO-opleidingen. Ook zijn de werkenden met deze opleidingen achteraf gezien niet minder tevreden over hun opleiding dan de afgestudeerden van de andere technische opleidingen.

Voor de komende jaren wordt een verbetering van het arbeidsmarktperspectief verwacht. De uitbreidingsvraag is naar verwachting $2,1 \%$ per jaar, ongeveer gelijk aan het gemiddelde voor HBO technisch. De vervangingsvraag is echter laag $(2,3 \%)$, vooral vanwege de relatief jonge opbouw van het personeelsbestand. Ook de komende jaren zullen er nog verhoudingsgewijs veel schoolverlaters met een dergelijke opleidingsachtergrond instromen op de arbeidsmarkt. Dit betekent dat er een licht overschot aan nieuwkomers voor deze opleiding zal ontstaan. Echter, door de tekorten die bij de andere hogere technische opleidingen dreigen, is de verwachting dat ook de afgestudeerden van HBO elektrotechniek/informatica hiervan meeprofiteren wat betreft hun toekomstig arbeidsmarktperspectief. Dit wordt dan ook, ondanks het aanvankelijk te verwachten overschot, als redelijk getypeerd. Werkgevers zullen dus rekening moeten houden met enige kans op moeilijkheden bij de personeelswerving.

Bij een gunstige economische ontwikkeling zal vooral ook deze opleiding profiteren. De verwachte uitbreidingsvraag is dan zelfs $3,2 \%$ gemiddeld per jaar. Het arbeidsmarktperspectief kan dan goed worden genoemd. Omdat slechts weinig werkenden met deze opleiding in de leeftijd zijn waarin men uitstroomt naar WAO of VUT, sorteren maatregelen ten aanzien van beide regelingen vooralsnog weinig effect. Een grotere doorstroom van het MBO technisch naar het HBO technisch heeft daarentegen wel veel invloed op de toekomstige arbeidsmarktpositie van afgestudeerden in deze richting: het arbeidsmarktperspectief wordt in een dergelijk scenario als matig getypeerd. Dit betekent overigens ook dat de kans dat werkgevers knelpunten gaan ondervinden bij de personeelsvoorziening klein geacht wordt. 


\section{MBO technisch laboratorium}

Van de werkgelegenheid van deze opleiding van in totaal 12.000 personen wordt één derde door vrouwen en twee derde door mannen vervuld. Dit maakt deze opleiding tot degene met het hoogste percentage vrouwen van alle technisch opleidingen. Erg opvallend is de relatief jonge leeftijdsopbouw van de werkgelegenheid: de helft van alle werkenden is jonger dan 30 jaar. Bijna $4 \%$ van de beroepsbevolking met deze opleiding was in 1993 werkloos. Onder vrouwen bedraagt het werkloosheidspercentage echter bijna $12 \%$.

De opleiding MBO technisch laboratorium is sterk afhankelijk van een beperkt aantal beroepen: de uitwijkmogelijkheden naar andere beroepen op aansluitend of hoger functieniveau zijn erg gering. Daarentegen is er sprake van een redelijk grote mate van flexibiliteit ten aanzien van de bedrijfssectoren. Men waaiert reeds op jonge leeftijd uit over een groot aantal bedrijfsklassen. Dit maakt tevens dat de conjunctuurgevoeligheid van de werkgelegenheid voor deze opleiding niet erg groot is.

Momenteel is zo'n $7 \%$ van de schoolverlaters van deze opleiding werkloos. Vergeleken met de andere technische opleidingen op MBO-niveau valt op dat een iets groter deel tenminste 4 maanden naar een werkkring heeft gezocht. Een gunstig aspect van deze opleiding is echter dat slechts een zeer gering deel van de schoolverlaters wordt onderbenut. Ook de inkomsten met een dergelijke opleiding zijn bij arbeidsmarktintrede zeker niet slecht te noemen. De schoolverlaters oordelen niet gunstig over de aansluiting onderwijs-arbeidsmarkt in kwalitatieve zin. Bijna $80 \%$ vindt achteraf dat in de opleiding meer aandacht had moeten worden besteed aan informatica. Ook over de aandacht voor het omgaan met apparatuur en materialen is men niet tevreden: $68 \%$ vindt dat dit beter gemoeten had. Bijna $40 \%$ is van mening dat de in de opleiding opgedane vakkennis ontoereikend is voor toetreding tot de arbeidsmarkt.

Voor de komende jaren wordt een bescheiden uitbreidingsvraag van gemiddeld $1,2 \%$ per jaar verwacht, iets meer dan de landelijke werkgelegenheidsgroei. Ook de vervangingsvraag is niet bijzonder hoog. Al met al resulteert dit in een totale vraag naar nieuwkomers van 3.000 personen in de periode 1993-2000. De verwachte arbeidsmarktinstroom vanuit de opleidingen ligt daar duidelijk boven, zodat een overschot aan nieuwkomers op de arbeidsmarkt wordt verwacht. Dit overschot zal liggen tussen de 400 en 700 personen, overeenkomend met $8 \%$ tot $17 \%$ van de verwachte instroom van schoolverlaters in de genoemde periode. Het arbeidsmarktperspectief voor deze opleiding wordt dientengevolge als matig geclassificeerd. Er is slechts een geringe kans dat werkgevers worden geconfronteerd met knelpunten ten aanzien van de personeelsvoorziening.

Bij een gunstige economische ontwikkeling kan de uitbreidingsvraag met $0,5 \%$-punt per jaar toenemen ten opzichte van het basisscenario. De perspectieven voor schoolverlaters op de arbeidsmarkt worden dan redelijk. Een afname van de vervangingsvraag als gevolg van een geringe instroom in de WAO en VUT heeft nauwelijks effect op het arbeidsmarktperspectief. Ook bij een grotere doorstroom vanuit het MBO naar het HBO blijt het arbeidsmarktperspectief voor schoolverlaters van het MBO technisch laboratorium matig. 


\section{MBO bouwkunde}

Van alle technische opleidingen op MBO-niveau is bouwkunde de grootste: ruim 150.000 werkenden, waarvan nog geen 5.000 vrouwen. Deze opleiding is daarmee goed voor ruim $10 \%$ van alle werkenden met een technische opleidingsachtergrond. De opleiding is sterk afhankelijk van de bouwsector. Maar liefst bijna $60 \%$ van de arbeidskrachten is in deze sector werkzaam. De uitwijkmogelijkheden naar andere bedrijfsklassen is derhalve gering. Bovendien maakt dit deze opleiding erg gevoelig voor conjuncturele schommelingen in de werkgelegenheid. Immers, vooral de bouw ondervindt vaak als eerste de problemen van een achterblijvende economische ontwikkeling. De uitwijkmogelijkheden naar beroepen op aansluitend of hoger functieniveau zijn gelijk aan het gemiddelde voor alle opleidingen. Belangrijke beroepsklassen zijn vooral metselaars, tegelzetters, straatmakers en stukadoors (werkgelegenheidsaandeel $25 \%$ ) en leidinggevenden bouw en industrie (14\%).

De werkloosheid onder schoolverlaters met een MBO-opleiding bouwkunde is erg laag: $3 \%$. Ongeveer $90 \%$ van de schoolverlaters heeft binnen 3 maanden een baan gevonden. Dit duidt derhalve op een momenteel gunstige arbeidsmarktpositie. Dit beeld wordt nog versterkt door een relatief laag percentage onderbenutting voor de schoolverlaters van deze opleiding: $15 \%$ tegenover gemiddeld ruim $30 \%$ voor de andere technische opleidingen op MBO-niveau. De bruto uurlonen voor schoolverlaters van deze opleiding zijn ongeveer gelijk aan het gemiddelde voor het MBO technisch. In vergelijking met de andere technische opleidingen op MBOniveau oordelen de schoolverlaters redelijk mild over hun opleiding ten aanzien van de aansluiting met de arbeidsmarkt. Toch vindt een belangrijk deel dat in de opleiding meer aandacht zou moeten worden besteed aan informatica en aan het omgaan met apparatuur en materialen.

Voor de periode tot het jaar 2000 wordt een redelijk arbeidsmarktperspectief voor schoolverlaters van MBO bouwkunde verwacht. Daarmee steekt deze opleiding in positieve zin af tegen de meeste andere technische opleidingen op MBO-niveau. Dit verschil wordt vooral veroorzaakt door enerzijds een wat hogere vervangingsbehoefte en anderzijds een relatief lage instroom van schoolverlaters op de arbeidsmarkt. Al met al wordt er een klein aanbodoverschot aan nieuwkomers van ongeveer 500 tot 1.000 personen verwacht, hetgeen nauwelijks $1 \%$ à $2 \%$ van de totale arbeidsmarktinstroom in de periode $1993-2000$.

Mocht de economie zich gunstiger ontwikkelen dan in het basisscenario voorzien, dan kan het arbeidsmarktperspectief voor schoolverlaters zelfs als goed worden gekwalificeerd. Dit betekent overigens ook dat werkgevers dan moeite zullen ondervinden bij het werven van (jong) personeel. Als echter aan de andere kant de maatregelen om de instroom in de WAO terug te dringen succesvol zijn en er minder mensen gebruik maken van de VUT, kunnen deze problemen in belangrijke mate worden verlicht. Voor schoolverlaters heeft dit echter ook belangrijke negatieve consequenties voor hun perspectief op de arbeidsmarkt. Dit wordt dan zelfs matig. 


\section{MBO weg- en waterbouwkunde}

In deze vrij kleine technische opleiding op MBO-niveau zijn ruim 20.000 mensen werkzaam, vrijwel allemaal mannen. Daarvan is twee derde jonger dan 40 jaar, iets meer dan het gemiddelde van alle technische MBOopleidingen. Eén op de drie arbeidskrachten met deze opleidingsachtergrond is werkzaam in de bouw, ruim $28 \%$ werkt in de overheidssector en nog eens bijna $15 \%$ in de sector overige commerciële dienstverlening. De beroepsklassen leidinggevenden bouw en industrie en bouwkundige technici, opzichters en werkvoorbereiders zijn de belangrijkste beroepsklassen voor deze opleiding. Beide hebben een werkgelegenheidsaandeel van bijna $20 \%$.

De werkgelegenheid voor deze opleiding is niet erg conjunctuurgevoelig. De uitwijkmogelijkheden naar beroepen op aansluitend of hoger functieniveau kunnen bovendien als gemiddeld worden gekwalificeerd. De uitwijkmogelijkheden naar andere bedrijfsklassen zijn echter gering: men is toch sterk op de bouwsector gericht. Dit geldt vooral ook voor de schoolverlaters. Bovendien zijn deze jongeren sterker afhankelijk van een beperkt aantal beroepen. Deze beperktere arbeidsmarktflexibiliteit maakt hen bovendien gevoeliger voor conjuncturele schommelingen in de werkgelegenheid.

Desondanks is de werkloosheid onder schoolverlaters van deze opleiding momenteel erg laag en heeft vrijwel niemand meer dan 3 maanden nodig om een baan te vinden. Dit is bovendien vaak een baan op MBO-niveau. Dit beeld van een momenteel gunstige arbeidsmarktpositie wordt nog versterkt door het verhoudingsgewijs hoge bruto uurinkomen van de schoolverlaters van deze opleiding.

Het toekomstig arbeidsmarktperspectief voor schoolverlaters is echter slecht. De vraag zal nog wel iets toenemen (circa 1\% per jaar), maar vooral de vervangingsbehoefte is gering, samenhangend met het grote aandeel jongeren met deze opleiding. Het aantal baanopeningen voor nieuwkomers bedraagt voor deze opleiding ruim 4.000 in de periode 1993-2000. Daar staat een vrij forse arbeidsmarktinstroom vanuit het onderwijs tegenover, zodat per saldo een overschot aan weg- en waterbouwkundigen op MBO-niveau ontstaat. Uitgedrukt in procenten van de instroom van schoolverlaters in de genoemde periode is een overschot van $10 \%$ tot $20 \%$.

Ook bij een gunstigere economische ontwikkeling zullen werkgevers niet echt in de problemen komen bij de werving van personeel met een dergelijke opleiding. De kans daarop blijft klein. Het arbeidsmarktperspectief voor schoolverlaters is in dat geval matig. Ook een verhoogde doorstroom naar het HBO biedt onvoldoende soelaas voor de schoolverlaters. 


\section{MBO metaalkunde}

Momenteel hebben ongeveer 62.000 werkenden een opleiding metaalkunde op MBO-niveau. Dit is $4,3 \%$ van het totaal aantal werkenden met een technische opleidingsachtergrond. De uitwijkmogelijkheden naar andere bedrijfsklassen zijn voor deze opleiding groot, ofschoon meer dan de helft in de metalektro werkzaam is. Ook de uitwijkmogelijkheden naar beroepen op aansluitend of hoger functieniveau zijn groot. De belangrijkste beroepsklassen zijn machinebank-, plaatwerkers en gereedschapsmakers (23\%) en lassers, constructiewerkers en edelmetaalsmeden (18\%). Ondanks deze grote mate van arbeidsmarktflexibiliteit kan de werkgelegenheid als conjunctuurgevoelig worden bestempeld. Er zijn geen betrouwbare gegevens beschikbaar van de huidige marktpositie van schoolverlaters van MBO metaalkunde.

De uitbreidingsvraag voor deze opleiding is relatief laag: 0,6\% gemiddeld per jaar, hetgeen iets lager is dan de werkgelegenheidsgroei die in totaal voor de komende jaren in Nederland wordt verwacht. De vervangingsvraag is daarentegen iets hoger dan het gemiddelde voor de technische MBO-opleidingen. Het totaal aantal baanopeningen bedraagt daarmee bijna 15.000, ofwel jaarlijks gemiddeld 3,2\%. Daar staat een arbeidsmarktinstroom van ruim 19.000 schoolverlaters tegenover. De resulterende arbeidsmarktsituatie is daarmee zo'n 800 tot 1.700 personen van het evenwicht verwijderd, rekening houdend met aanpassingen in vraag en aanbod die zullen optreden als gevolg van veranderende 'prijzen' (loon, aantrekkelijkheid van de baan enz.).

Werkgevers zullen weinig moeilijkheden hebben bij de werving van personeel met een dergelijke opleiding. Het arbeidsmarktperspectief voor schoolverlaters van deze opleiding kan matig worden genoemd. In deze situatie komt echter verbetering wanneer de economie zich gunstiger ontwikkelt dan voorzien in het basisscenario. Bij een gunstige economische ontwikkeling kan de uitbreidingsvraag verdubbelen tot $1,2 \%$ gemiddeld per jaar. Het arbeidsmarktperspectief voor schoolverlaters wordt dan redelijk. 
Een kleine technische opleiding op MBO-niveau betreft de richting fijnmechanische techniek. De werkgelegenheid voor deze opleiding is 14.000 personen. Deze zijn met name werkzaam in de metalektro (36\%) en de handel (21\%). De uitwijkmogelijkheden naar andere bedrijfsklassen kunnen echter als groot worden getypeerd. Bovendien bestaan er veel mogelijkheden om uit te waaieren over de verschillende beroepen. De werkgelegenheid voor degenen met een opleiding MBO fijnmechanische techniek is daardoor niet bijzonder conjunctuurgevoelig. Helaas kunnen geen betrouwbare uitspraken gedaan worden over de actuele positie en de risicopositie van schoolverlaters van deze opleiding op de arbeidsmarkt.

In vergelijking met de andere technische opleidingen op MBO-niveau is een groot gedeelte van de werkenden 40 jaar of ouder. Terwijl dit gemiddeld voor het MBO technisch om circa $40 \%$ van de werkenden gaat, behoort bij de richting fijnmechanische techniek meer dan de helft tot deze leeftijdscategorie. Daarvan is $20 \%$-punt 50 jaar of ouder. Dit heeft tot gevolg dat de toekomstige vervangingsvraag voor deze opleiding vrij hoog is: gemiddeld jaarlijks $3,4 \%$, hetgeen verreweg het hoogste is van alle technische MBO-opleidingen. Ondanks een vrij bescheiden uitbreidingsvraag, ontstaat er op deze wijze toch een grote behoefte aan nieuwkomers op de arbeidsmarkt. Het totaal aantal baanopeningen voor nieuwkomers bedraagt 4.400 in de periode 1993-2000. Aan deze behoefte kan vanuit het onderwijs niet worden voldaan. Er ontstaat een tekort aan enkele honderden arbeidskrachten. In procenten van de instroom van schoolverlaters gaat het dan om $13 \%$ tot maar liefst $27 \%$.

Werkgevers zullen derhalve problemen gaan ondervinden bij de werving van personeel met deze opleidingsachtergrond. Het arbeidsmarktperspectief voor schoolverlaters kan als gunstig worden aangemerkt. Dit beeld versterkt zich alleen maar als de economische ontwikkeling positiever uitpakt dan in het behoedzame basisscenario. Door maatregelen te nemen om de instroom in de WAO te beperken, alsmede door een verminderde toetreding tot de VUT-regelingen kan een beperkte daling van de vervangingsbehoefte worden bewerkstelligd. Deze daling is echter onvoldoende om de spanning op de arbeidsmarkt te verlichten. Met andere woorden: het perspectief voor schoolverlaters op de arbeidsmarkt blijft ook in een dergelijke situatie gunstig. 


\section{MBO werktuigbouwkunde}

Met 88.000 werkenden behoort MBO werktuigbouwkunde tot de grootste technische opleidingen. Ruim $6 \%$ van alle werkende technisch opgeleiden heeft een dergelijke achtergrond. Meer dan een derde van de arbeidskrachten met deze opleiding is werkzaam in de metalektro. Daarnaast zijn de bouw (10\%), de overige commerciële dienstverlening (eveneens $10 \%$ ) en de handel (9\%) belangrijke bedrijfssectoren voor deze opleiding. De belangrijkste beroepsklassen zijn leidinggevenden bouw en industrie (15\%) en onderhoudsmonteurs, fietsen- en instrumentmakers (14\%).

Werktuigbouwkundigen op MBO-niveau hebben erg veel mogelijkheden om uit te wijken naar andere bedrijfsklassen en/of andere beroepen of aansluitend of hoger functieniveau. Desalniettemin is de conjunctuurgevoeligheid van de werkgelegenheid voor deze opleiding groot. Ook schoolverlaters hebben doorgaans te maken met een conjunctuurgevoelige werkgelegenheidssituatie. Daarentegen hebben schoolverlaters minder uitwijkmogelijkheden op de arbeidsmarkt. De werkenden waaieren derhalve pas op latere leeftijd uit over de verschillende sectoren en beroepen.

De werkloosheid onder schoolverlaters van deze opleiding bedraagt ongeveer $5 \%$, vrijwel gelijk aan het gemiddelde voor het gehele MBO technisch. Wel heeft een behoorlijk deel van de schoolverlaters lang naar een baan moeten zoeken, $6 \%$ zelfs langer dan een half jaar. Opvallend zijn echter de hoge salarissen die gemiddeld met deze opleiding worden bereikt. In vergelijking met het gemiddelde voor MBO technisch verdienen zij maar liefst ongeveer $\mathbf{4 0 0}$ gulden per maand meer (bij volledige werkweek).

De schoolverlaters zijn vooral ontevreden over de aandacht die in hun opleiding aan informatica of automatisering is besteed. Bijna drie kwart acht dit onvoldoende. Daarentegen oordeelt men positief over de vakkennis die in de opleiding is opgedaan. Ook over de aandacht die is besteed aan het omgaan met apparatuur of materialen is men in verhouding met de andere opleidingen redelijk tevreden, ook al is nog ruim $40 \%$ van mening dat hierin meer aandacht zou moeten worden besteed.

Voor de periode tot het jaar 2000 wordt een matig arbeidsmarktperspectief verwacht. Er ontstaat naar verwachting een overschot aan nieuwkomers van tussen 2.000 tot 4.000 personen, hetgeen $7 \%$ tot $14 \%$ van de arbeidsmarktinstroom van schoolverlaters is. Deze instroom bedraagt gemiddeld bijna $4 \%$ per jaar, ongeveer gelijk aan het gemiddelde voor de technische opleidingen op MBO-niveau. Ook het aantal baanopeningen voor nieuwkomers is redelijk in overeenstemming met het gemiddelde voor het MBO technisch. De totale vraag naar nieuwkomers is 20.000 personen in de periode 1993-2000. Daarvan is circa een kwart het gevolg van de uitbreidingsvraag en vloeit drie kwart voort uit de vervangingsbehoefte.

Ook bij een gunstigere economische ontwikkeling blijt het perspectief voor schoolverlaters op de arbeidsmarkt matig. De kans dat werkgevers de komende jaren problemen zullen ondervinden bij de werving van nieuw personeel moet derhalve klein worden geacht. Ook veranderingen ten aanzien van de arbeidsmarktuitstroom van ouderen en de doorstroom binnen het onderwijs naar het HBO sorteren nauwelijks effect op de arbeidsmarktperspectieven van schoolverlaters, c.q. de kans dat werkgevers knelpunten ondervinden bij de personeelsvoorziening. 
In totaal werken er in Nederland circa 63.000 mensen met een opleiding MBO motorvoertuigentechniek. Dat komt overeen met $4,4 \%$ van het totaal aantal werkenden met een technische opleiding. De sector overige commerciële dienstverlening is voor deze opleiding het belangrijkste. Ruim $40 \%$ van de werkenden heeft een baan in deze sector. Ook de handel is goed voor een aanzienlijk deel van de werkgelegenheid van deze opleidingscategorie (21\%). De werkgelegenheid voor deze opleiding doet zich vooral voor in de beroepsklassen automonteurs en (motor)rijwielherstellers (30\%) en leidinggevenden bouw en industrie $(13 \%)$.

De conjunctuurgevoeligheid van de werkgelegenheid voor deze opleiding is niet erg groot. De uitwijkmogelijkheden naar andere bedrijfsklassen of beroepen zijn echter ook niet riant te noemen. Schoolverlaters hebben zelfs een vrij beperkt bereik op de arbeidsmarkt. Zij hebben weinig mogelijkheden om uit te wijken naar andere bedrijfsklassen, terwijl de uitwijkmogelijkheden naar beroepen op aansluitend of hoger functieniveau zelfs als erg klein worden bestempeld.

De schoolverlaters met deze opleiding van het schooljaar 1991-1992 hebben in het algemeen snel werk gevonden, drie kwart zelfs direct in aansluiting op de opleiding. De werkloosheid ongeveer een jaar na schoolverlaten is dan ook erg laag (2\%). Ondanks deze ogenschijnlijke krapte op de arbeidsmarkt blijt het gemiddeld bruto uurinkomen voor deze opgeleiden opvallend achter bij de andere technische opleidingen op MBO-niveau. Per maand scheelt dit al gauw 100 gulden; in vergelijking met bijvoorbeeld MBO werktuigbouwkunde maar liefst ruim 400 gulden bruto per maand (bij volledige werkweek). Dit verschil zou overigens kunnen samenhangen met het grote percentage deeltijdwerkers bij deze opleiding, hetgeen er op wijst dat een groot deel van de schoolverlaters naast de huidige baan nog verder leert. Tot het voltooien van die vervolgopleiding krijgt men wellicht een lager salaris.

Verwacht wordt dat de komende jaren een fors aantal schoolverlaters met een opleiding MBO motorvoertuigentechniek de arbeidsmarkt zal betreden. Het gaat daarbij om ruim 28.000 personen, ofwel jaarlijks $5,3 \%$ van het aantal werkenden. De vraag naar nieuwkomers is onvoldoende om dit nieuwe aanbod te kunnen absorberen. Zowel uitbreidings- als vervangingsvraag liggen iets onder het gemiddelde voor de technische opleidingen op MBO-niveau. Dit betekent dat er een aanzienlijk overschot aan arbeidskrachten met een dergelijke opleiding ontstaat. Dit kan wel oplopen tot 6.000 mensen, hetgeen neerkomt op $20 \%$ van de totale instroom van schoolverlaters op de arbeidsmarkt in de prognoseperiode 1993-2000. Het arbeidsmarktperspectief voor schoolverlaters wordt daarom als ronduit slecht bestempeld. De kans dat werkgevers moeilijkheden zullen hebben bij de werving van nieuwe arbeidskrachten wordt zeer klein geacht.

Dit voor schoolverlaters negatieve beeld is erg robuust. Ook bij een gunstige economische ontwikkeling blijven de perspectieven op de arbeidsmarkt slecht. Een in het algemeen hogere doorstroom van het MBO technisch naar het HBO technisch biedt eveneens weinig mogelijkheden. De situatie kan bovendien nog verslechteren als de vervangingsvraag, vanwege de afnemende arbeidsmarktuitstroom naar WAO of VUT, in de toekomst lager is. 
Bijna 150.000 werkenden in Nederland hebben een opleiding MBO elektrotechniek gevolgd. Dat is ruim $10 \%$ van alle werkenden met een technische opleidingsachtergrond. De uitwijkmogelijkheden voor deze opleiding zijn, zowel naar andere bedrijfssectoren als naar andere beroepen, relatief groot. Zo zijn zij onder meer werkzaam in de metaal, elektrotechnische en transportmiddelenindustrie $(23 \%)$, de bouw (18\%) en de handel (16\%). De twee belangrijkste beroepsklassen zijn elektriciens, elektro- en telecom-(onderhouds)monteurs (34\% van de werkgelegenheid) en leidinggevenden bouw en industrie (12\%). Het percentage vrouwen onder de werkenden is erg laag. In totaal gaat het daarbij om minder dan 5.000 vrouwen. De leeftijdsopbouw van de werkgelegenheid is redelijk evenwichtig.

In vergelijking met de andere technische opleidingen op MBO-niveau is het werkloosheidspercentage onder schoolverlaters voor deze opleiding hoog: $7 \%$. Bovendien heeft een aanzienlijk deel van de schoolverlaters langer dan gemiddeld moeten zoeken naar een baan. Verder duidt het hoge percentage onderbenutting onder de schoolverlaters (33\%) op een vrij zwakke arbeidsmarktpositie. Het gemiddeld bruto inkomen ligt echter iets boven het gemiddelde voor MBO technisch. De werkgelegenheid voor deze opleiding is voorts relatief gevoelig voor de conjuncturele ontwikkeling. Dit geldt niet alleen voor schoolverlaters, maar ook voor de beroepsbevolking als geheel. Schoolverlaters hebben daarentegen wat minder mogelijkheden dan reeds langer werkenden om uit te wijken naar beroepen op aansluitend of hoger functieniveau. Wel zijn zij inzetbaar in een groot aantal bedrijfssectoren.

De schoolverlaters van deze opleiding zijn erg ontevreden over de aandacht die in hun opleiding wordt besteed aan het omgaan met apparatuur of materiaal. Dit kan dus als een (kwalitatief) arbeidsmarktknelpunt worden gezien. Ook op het punt van informatica/automatisering is men niet tevreden over de opleiding. Bovendien is een aanzienlijk deel van de schoolverlaters van mening dat praktijkoriëntatie of stage een belangrijkere component van de opleiding zou moeten zijn.

De huidige als relatief zwak bestempelde arbeidsmarktpositie zet zich ook in de komende jaren naar verwachting voort. Het arbeidsmarktperspectief voor schoolverlaters wordt voor deze opleiding als slecht gekenmerkt. Er dreigt een overschot van enkele duizenden nieuwkomers op de arbeidsmarkt. Deze slechte arbeidsmarktperspectieven zijn een cumulatie van enkele negatieve of minder positieve ontwikkelingen: de uitbreidingsvraag is iets lager dan bij de andere technische opleidingen op MBO-niveau; de vervangingsvraag is aan de lage kant; bovendien wordt er een relatief grote instroom van schoolverlaters op de arbeidsmarkt verwacht. Dit alles maakt dat werkgevers op dit punt een vrij sterke arbeidsmarktpositie hebben: de kans op knelpunten bij de personeelsvoorziening is erg klein.

In deze situatie kan enige verandering optreden als de economie zich gunstiger ontwikkelt dan wordt voorzien in het basisscenario. In plaats van $0,7 \%$ gemiddeld per jaar kan dan een uitbreidingsvraag van $1,3 \%$ worden gerealiseerd. De arbeidsmarktperspectieven voor schoolverlaters zijn echter ook dan slechts matig. Een in het algemeen grotere doorstroom van het MBO technisch naar het HBO technisch biedt weinig soelaas voor de toekomstige schoolverlaters van het MBO. Het arbeidsmarktperspectief is in dat geval, evenals in het basisscenario, slecht. 


\section{MBO procestechniek}

Een kleine 20.000 werkenden heeft een opleiding procestechniek op MBO-niveau gevolgd. Daarmee vertegenwoordigt deze opleiding $1,2 \%$ van de totale werkgelegenheid voor technisch opgeleiden. Opvallend is de relatief lage gemiddelde leeftijd. Maar liefst $77 \%$ is jonger dan 40 jaar, terwijl dit gemiddeld genomen over alle technische opleidingen op MBO-niveau slechts ongeveer $60 \%$ is. De chemische sector is verreweg het belangrijkste voor deze opleidingscategorie. Zo'n $44 \%$ van de arbeidskrachten is werkzaam in deze sector. De belangrijkste beroepsklasse is produktiepersoneel chemische industrie.

Ondanks deze sterke vertegenwoordiging in de chemie, hebben degenen met een MBO-opleiding procestechniek nog redelijk veel mogelijkheden om uit te wijken naar andere bedrijfssectoren of beroepen. Deze worden beide als gemiddeld gekwalificeerd. Bovendien is de werkgelegenheid voor deze opleiding niet erg conjunctuurgevoelig. Er zijn geen betrouwbare gegevens over de arbeidsmarktpositie van schoolverlaters met een dergelijke opleidingsachtergrond.

De uitbreidingsvraag voor deze opleiding bedraagt naar verwachting $0,9 \%$ gemiddeld per jaar, iets hoger dan het gemiddelde voor alle opleidingen en tevens iets hoger dan het gemiddelde voor het totale MBO technisch. Zoals op grond van de leeftijdsopbouw mocht worden verwacht, is de vervangingsvraag voor deze opleiding erg laag: $1,3 \%$ gemiddeld per jaar. Echter, ook de arbeidsmarktinstroom van schoolverlaters is de komende jaren naar verwachting laag $(2,2 \%)$. Dit betekent dat een redelijk evenwichtige arbeidsmarkt kan ontstaan. Omdat echter bij de meeste andere technische opleidingen op MBO-niveau overschotten dreigen is het perspectief voor schoolverlaters op de arbeidsmarkt toch slechts matig. Zij ondervinden hinder van een toenemende concurrentie van andere technici.

Wanneer echter de economie aantrekt, is het arbeidsmarktperspectief voor schoolverlaters duidelijk gunstiger. $\mathrm{Er}$ is dan een grote kans dat werkgevers worden geconfronteerd met problemen ten aanzien van de werving van nieuw personeel. Ook als er in toenemende mate sprake is van een doorstroom van het MBO technisch naar het HBO technisch kan er ten opzichte van het basisscenario een verbetering van het arbeidsmarktperspectief voor schoolverlaters van deze opleiding ontstaan. 


\section{VBO bouwtechniek}

Van alle werkende technisch opgeleiden in Nederland heeft bijna $10 \%$ een opleiding VBO bouwtechniek gevolgd. In totaal zijn er bijna 140.000 werkenden met een dergelijke opleidingsachtergrond, vrijwel uitsluitend mannen. Daarvan werkt ruim $40 \%$ in de bouwsector, die daarmee verreweg het belangrijkste is voor deze opleiding. Ruim een kwart van de arbeidskrachten is werkzaam in de beroepsklasse timmerlieden e.a. houtbewerkers. Andere belangrijke beroepsklassen zijn metselaars, tegelzetters, straatmakers en stukadoors (10\%) en huis-, scheeps- en constructieschilders $(7 \%)$.

Vooral voor jongeren brengt deze opleiding erg grote risico's op de arbeidsmarkt met zich mee. Schoolverlaters zijn namelijk voor hun werkgelegenheid erg afhankelijk van enkele conjunctuurgevoelige sectoren. Ook de uitwijkmogelijkheden naar andere beroepen op aansluitend of hoger functieniveau zijn gering. Naarmate de werkenden met deze opleiding ouder worden waaieren ze vaker uit over verschillende beroepen en bedrijfssectoren. De uitwijkmogelijkheden kunnen dan als gemiddeld worden getypeerd. Ook de conjunctuurgevoeligheid van de werkgelegenheid valt dan mee.

Momenteel vinden de schoolverlaters van deze opleiding vrij snel een baan. Vrijwel niemand hoeft langer dan drie maanden te zoeken. Het werkloosheidspercentage onder schoolverlaters is voor deze opleiding slechts $3 \%$. Ook het percentage onderbenutting is aan de lage kant: $6 \%$. Verder is een belangrijk positief aspect van de arbeidsmarktpositie van deze opleiding dat de gemiddelde inkomens in vergelijking met de andere technische VBO-opleidingen hoog zijn. Zij verdienen bruto ruim 100 gulden per maand meer. Ten opzichte van het gehele VBO is dat zelfs ruim 200 gulden. De schoolverlaters zijn echter in het algemeen ontevreden over de kennis die zij in de opleiding hebben opgedaan van het omgaan van apparatuur en materialen. Ook zou men graag zien dat er meer aandacht werd besteed aan praktijkoriëntatie of stage. Deze VBO-opleiding schiet op dit punt duidelijk tekort om een goede aansluiting met de arbeidsmarkt te bewerkstelligen.

Zoals vrijwel alle (technische) VBO-opleidingen, zal ook bouwtechniek te maken krijgen met een licht dalende behoefte aan arbeidskrachten: de uitbreidingsvraag bedraagt $-0,7 \%$ gemiddeld per jaar. De totale vraag naar nieuwkomers moet derhalve geheel voortvloeien uit de vervangingsvraag. In totaal is er in de periode 19932000 een vraag naar ruim 25.000 nieuwkomers op de arbeidsmarkt. Aan deze behoefte kan vanuit de opleidingen niet worden voldaan. $\mathrm{Er}$ ontstaat een tekort ten opzichte van het evenwicht van 1.000 tot 2.000 nieuwkomers. De schoolverlaters van deze opleiding zullen echter geconfronteerd worden met een toenemende concurrentie van degenen die een opleiding op MBO-niveau hebben gevolgd. De arbeidsmarktperspectieven worden daarom niet als goed, maar slechts als redelijk getypeerd. Werkgevers zullen desalniettemin enige problemen ondervinden bij het aantrekken van personeel met een opleiding VBO bouwtechniek.

Als de economie zich de komende jaren gunstiger gaat ontwikkelen dan momenteel wordt voorzien, zullen de schoolverlaters van deze opleiding daarvan zeker profiteren. Het arbeidsmarktperspectief voor schoolverlaters wordt dan goed. $\mathrm{Er}$ is dan weliswaar nog sprake van een kleine negatieve uitbreidingsvraag, maar de concurrentie van MBO-opgeleiden wordt een stuk minder hevig. Maatregelen om de instroom in de WAO terug te dringen en of beperking van de VUT-mogelijkheden, die beide hun neerslag krijgen in een lagere vervangingsvraag, hebben opvallend genoeg nauwelijks substantiële invloed op de arbeidsmarktperspectieven van schoolverlaters van deze opleiding. 


\section{VBO installatietechniek}

Ruim 10.000 werkenden hebben VBO installatietechniek als opleidingsachtergrond. Daarmee is dit een van de kleinere technische opleidingen op VBO-niveau. Ongeveer de helft van de werkenden heeft een baan in de bouw. De belangrijkste beroepsklasse voor deze opleiding is loodgieters, sanitair-installateurs en -reparateurs. Ruim een derde van de arbeidskrachten is in deze beroepsklasse werkzaam.

De werkgelegenheid voor deze opleiding moet als conjunctuurgevoelig worden bestempeld. Er bestaat derhalve een sterke afhankelijkheid van de economische situatie. Daarnaast heeft deze opleiding als risico dat de uitwijkmogelijkheden naar andere beroepen zeer beperkt zijn. Wel kan men wat makkelijker naar andere bedrijfssectoren dan de bouw uitwijken. Het is helaas niet bekend hoe de positie van schoolverlaters op deze punten is. Tevens zijn geen betrouwbare gegevens voorhanden van de actuele arbeidsmarktpositie van schoolverlaters.

Opvallend bij deze opleiding is dat er onder werkenden veel jongeren zijn. Ruim drie kwart van de arbeidskrachten is jonger dan 40. Dit heeft repercussies voor de vervangingsbehoefte. Deze is, in vergelijking met de andere opleidingen van het VBO technisch, erg laag. Daarnaast moet worden beseft dat de uitbreidingsvraag negatief is, overigens evenals bij de andere technische VBO-opleidingen. De instroom van schoolverlaters op de arbeidsmarkt is weliswaar beperkt, maar toch zodanig dat een licht overschot aan nieuwkomers ontstaat. Het arbeidsmarktperspectief voor schoolverlaters wordt als matig gekwalificeerd, mede omdat er tevens sprake zal zijn van een hevige concurrentie van MBO-opgeleiden in de technische richting.

Bij een gunstigere economische ontwikkeling kan er sprake zijn van een kleine positieve uitbreidingsvraag. Dit is echter onvoldoende om de arbeidsmarktperspectieven er duidelijk beter uit te laten zien: deze blijven matig. Ook bij een sterke economische groei hoeven werkgevers zich derhalve weinig zorgen te maken dat zij problemen ondervinden bij het werven van personeel met deze opleiding. 


\section{VBO metaalkunde}

Met 140.000 , vrijwel allemaal mannelijke, werkenden is VBO metaalkunde de grootste opleiding van het VBO technisch. Ruim $35 \%$ van hen is werkzaam in de metaal, elektrotechnische en transportmiddelenindustrie. Ook de bouwsector (werkgelegenheidsaandeel $11 \%$ ), de handel (10\%) en de sector vervoer en communicatie (10\%) zijn belangrijk voor deze opleiding. De twee belangrijkste beroepsklassen zijn lassers, constructiewerkers en edelsmeden $(15 \%)$ en machinebank-, plaatwerkers en gereedschapsmakers $(10 \%)$.

De werkenden met deze opleiding kunnen uitwijken naar een breed scala van beroepen. Ook de uitwijkmogelijkheden naar andere bedrijfsklassen zijn groot, hetgeen duidelijk als positief aspect van de arbeidsmarktpositie moet worden beschouwd. Een belangrijk nadeel is echter dat ook de uitwijksectoren erg conjunctuurgevoelig zijn, zodat deze opleiding in sterke mate de gevolgen ondervindt van een economische depressie. Ook voor schoolverlaters zijn de uitwijkmogelijkheden naar andere bedrijfsklassen en beroepen groot, maar is de werkgelegenheid erg conjunctuurgevoelig.

Ondanks deze conjunctuurgevoeligheid is de werkloosheid onder schoolverlaters momenteel niet erg groot, namelijk slechts $4 \%$. Wel heeft zo'n $8 \%$ van de schoolverlaters meer dan drie maanden naar een baan moeten zoeken. Bovendien heeft bijna $10 \%$ van de werkenden een baan op het laagste niveau moeten accepteren. Daar staat overigens tegenover dat het bruto loon voor deze opleiding gemiddeld relatief hoog is. Toch laat met name de kwalitatieve aansluiting van de opleiding op de arbeidsmarkt te wensen over. De schoolverlaters hadden graag gezien dat er meer aandacht was besteed aan informatica/automatisering en het omgaan met materialen en apparatuur. Dit zou bijvoorbeeld kunnen in de vorm van stage of lessen praktijkoriëntatie.

Voor de periode tot 2000 wordt voor deze opleiding een redelijk arbeidsmarktperspectief verwacht. Weliswaar is er sprake van een forse negatieve uitbreidingsvraag van gemiddeld $-1,1 \%$ per jaar, maar daar staat tegenover dat bijna 30.000 arbeidskrachten in de periode 1993-2000 zullen moeten worden vervangen door nieuwkomers. Dit is meer dan beschikbaar zal komen vanuit de opleidingen, hetgeen impliceert dat er een tekort ontstaat. Vanwege het verwachte overschot aan MBO-opgeleiden, kunnen werkgevers echter uitwijken door MBO'ers in plaats van VBO'ers te werven. Toch moeten werkgevers rekening houden met een redelijke kans op knelpunten bij de werving van nieuwe arbeidskrachten met een dergelijke opleidingsachtergrond. Dit resultaat is bovendien erg robuust voor alternatieve scenario's met betrekking tot uitbreidingsvraag, vervangingsvraag en instroom van schoolverlaters. 


\section{VBO motorvoertuigentechniek}

De opleiding VBO motorvoertuigentechniek is door 46.000 van de werkenden gevolgd. Dit betekent dat $3,2 \%$ van de werkende technisch opgeleiden een dergelijke opleidingsachtergrond heeft. De uitwijkmogelijkheden naar andere bedrijfssectoren zijn voor deze opleiding redelijk groot. Zo werken er arbeidskrachten met deze opleiding in onder meer de sectoren overige commerciële dienstverlening $(22 \%)$, vervoer en communicatie $(15 \%)$, metalektro $(13 \%)$ en handel (eveneens $13 \%$ ). De uitwijkmogelijkheden naar andere beroepen zijn minder groot. De belangrijkste beroepsklassen voor deze opleiding zijn automonteurs en (motor)rijwielherstellers $(17 \%)$ en chauffeurs en spoorwegpersoneel $(15 \%)$.

Schoolverlaters hebben echter veel minder uitwijkmogelijkheden op de arbeidsmarkt. De mogelijkheden om uit te wijken naar beroepen op aansluitend of hoger functieniveau worden zelfs als erg klein getypeerd. De werkgelegenheid voor VBO-opgeleiden motorvoertuigentechniek is echter niet bijzonder conjunctuurgevoelig. Dit geldt zowel voor de schoolverlaters, als ook voor degenen die reeds langer op de arbeidsmarkt verblijven.

Momenteel is de werkloosheid onder schoolverlaters van deze opleiding hoog: $11 \%$. Bovendien heeft meer dan $10 \%$ van de schoolverlaters meer dan drie maanden naar een baan moeten zoeken, hetgeen in vergelijking met de andere VBO-opleidingen aan de hoge kant is. Opvallend is verder dat de verdiensten met deze opleiding voor schoolverlaters erg laag zijn, zeker in vergelijking met de andere technische VBO-opleidingen. Het verschil bedraagt maar liefst ruim 150 gulden bruto per maand. Het percentage onderbenutting onder schoolverlaters is echter vrij laag. Bovendien oordelen de schoolverlaters positief over de kwalitatieve aansluiting van hun opleiding bij de vereisten van de arbeidsmarkt. Wel zou men graag zien dat er in de opleiding meer aandacht wordt besteed aan materialen- en apparatuurkennis.

De arbeidsmarktinstroom van schoolverlaters is naar verwachting de komende jaren erg laag. Uitgedrukt in procenten van het aantal werkenden is dit jaarlijks gemiddeld slechts $1,4 \%$. Echter, deze opleiding zal, evenals de meeste andere VBO-opleidingen, te maken krijgen met een negatieve uitbreidingsvraag. De totale vraag naar nieuwkomers moet dus volledig komen van de arbeidskrachten die vanwege pensionering, VUT, WAO e.d. uitstromen van de arbeidsmarkt, tenminste voor zover de opengevallen plaatsen worden opgevuld. Daarbij gaat het naar verwachting in de periode $1993-2000$ om circa 7.700 personen, aanzienlijk meer dan de opleidingen aan nieuwkomers leveren. Het tekort dat ontstaat kan echter eenvoudig worden opgevuld doordat op andere arbeidsmarktsegmenten, met name op MBO-niveau, overschotten ontstaan. De perspectieven voor schoolverlaters van deze opleiding op de arbeidsmarkt zijn daardoor slechts matig. De kans dat werkgevers problemen zullen ondervinden bij de personeelsvoorziening wordt vrij klein geacht.

Bij een gunstigere economische ontwikkeling dan voorzien in het basisscenario zal de concurrentie voor deze opleiding van met name MBO-opgeleiden wat afnemen. De arbeidsmarktperspectieven worden dan ook iets gunstiger ingeschat. Ook wanneer meer MBO'ers besluiten door te leren in het HBO in plaats van zich aan te bieden op de arbeidsmarkt, kan een aanzienlijke verbetering van het arbeidsmarktperspectief voor schoolverlaters van VBO motorvoertuigentechniek optreden. In beide gevallen zullen werkgevers echter iets meer problemen tegenkomen bij de werving van nieuw personeel. 


\section{VBO elektrotechniek}

Zo'n ruim 60.000 werkenden in Nederland heeft VBO elektrotechniek als hoogst behaalde opleiding. Deze opgeleiden zijn met name werkzaam in de metalektro en de bouw, beide met een werkgelegenheidsaandeel van om en nabij de $20 \%$, maar ook de bedrijfssectoren handel (13\%) en vervoer en communicatie (11\%) zijn belangrijk voor deze opleiding. Bij de beroepsklassen is elektriciens, elektro- en telecom(onderhouds)monteurs verreweg het belangrijkste. Ruim een kwart van de arbeidskrachten is in deze beroepsklasse werkzaam. Opvallend is dat veel van de werkenden nog relatief jong is: ruim drie kwart heeft de 40-jarige leeftijd nog niet bereikt.

Jongeren die van deze opleiding afkomen hebben erg weinig mogelijkheden om uit te wijken naar andere arbeidsmarktsegmenten. De flexibiliteit met betrekking tot zowel de bedrijfsklassen als de beroepen is erg gering. Dit betekent bovendien dat de werkgelegenheid voor deze schoolverlaters erg conjunctuurgevoelig is. Naarmate men echter wat langer op de arbeidsmarkt verblijt komt in deze situatie snel enige verbetering.

De werkloosheid onder schoolverlaters van VBO elektrotechniek is momenteel niet erg hoog. Ongeveer $95 \%$ van de schoolverlaters van 1991-1992 heeft binnen drie maanden een baan gevonden. Ook het percentage onderbenutting is niet bijzonder hoog, maar overeenkomend met het gemiddeld voor VBO technisch. Wel zijn de salarissen aan de lage kant wanneer dit wordt vergeleken met de andere technische opleidingen op VBOniveau. Het verschil kan oplopen tot gemiddeld 250 gulden bruto per maand. Mogelijk kan dit verschil worden verklaard door de slechte kwalitatieve aansluiting van het onderwijs bij de arbeidsmarkt. Zo is ruim de helft van de schoolverlaters van mening dat in de opleiding te weinig aandacht wordt besteed aan vaktheoretische kennis. Ook informatica en het omgaan met apparatuur en materialen komt volgens de schoolverlaters te weinig aan bod in de opleiding.

Werkgevers zullen de komende jaren weinig problemen ondervinden bij het werven van personeel met deze opleiding. In de eerste plaats zal er naar verwachte sprake zijn van een negatieve uitbreidingsvraag. Deze bedraagt jaarlijks gemiddeld $-1,1 \%$. Ook de vervangingsvraag is niet bijzonder hoog. Hoewel ook de arbeidsmarktinstroom vanuit de opleidingen aan de lage kant is, wordt toch een overschot van enkele honderden nieuwkomers verwacht. Wanneer daarnaast nog rekening wordt gehouden met de concurrentie die VBO-schoolverlaters in toenemende mate zullen ondervinden van MBO'ers, dan kan worden geconcludeerd dat het arbeidsmarktperspectief voor deze opleiding slechts matig is. Ook bij een gunstigere economische ontwikkeling komt daarin weinig verbetering. 


\section{VBO grafische techniek}

Meest opvallend bij deze kleine technisch opleiding, circa 9.000 werkenden, is de relatief hoge gemiddelde leeftijd. Zo is één derde van de arbeidskrachten tussen de 40 en 50 , terwijl dit voor de rest van het VBO technisch slechts ongeveer een kwart is. Deze opleiding is verder erg afhankelijk van de grafische industrie. Ongeveer de helft van de arbeidskrachten is in deze sector als drukker of produktiemedewerker werkzaam. De werkgelegenheid voor deze opleiding is echter niet bijzonder conjunctuurgevoelig. Helaas zijn er geen betrouwbare gegevens beschikbaar over de actuele en risicopositie van schoolverlaters van deze opleiding.

Voor de komende jaren wordt voor deze opleiding een redelijk evenwichtige arbeidsmarkt verwacht. Het arbeidsmarktperspectief voor schoolverlaters van deze opleiding wordt als redelijk getypeerd. Er bestaat ook een redelijke kans dat werkgevers moeite zullen krijgen bij de werving van nieuw personeel. Dit is dan met name het gevolg van de relatief hoge vervangingsvraag voor deze opleiding, vanzelfsprekend samenhangend met de reeds gememoreerde hoge gemiddelde leeftijd. Verder is het opmerkelijk dat de werkgelegenheid voor deze opleiding de komende jaren min of meer gelijk blijft, dit terwijl de andere technische VBO-opleidingen te maken hebben met een aanzienlijke negatieve uitbreidingsvraag. De arbeidsmarktinstroom van schoolverlaters is echter in vergelijking met de andere technische opleidingen op VBO-niveau ook aan de hoge kant. Dit hangt waarschijnlijk samen met het feit dat vanuit deze opleidingen minder mensen doorstromen naar onderwijs op MBO-niveau.

Voor de schoolverlaters kan er wat betreft het arbeidsmarktperspectief een belangrijke kink in de kabel komen. Deze treedt op wanneer de maatregelen om de instroom in de WAO te beperken succesvol zijn en er tevens een reductie plaatsvindt ten aanzien van de instroom in de VUT. De vervangingsvraag zal in een dergelijke situatie iets lager zijn. Bovendien neemt de concurrentie vanuit andere opleidingen toe. Het arbeidsmarktperspectief wordt voor deze opleiding in dat scenario matig. 


\section{VBO consumptieve techniek}

Meer dan de helft van de $\mathbf{2 6 . 0 0 0}$ werkenden met een opleiding consumptieve techniek op VBO-niveau is jonger dan 30 jaar. Bovendien werken er bij deze opleiding veel mensen in deeltijd. De sector voedings- en genotmiddelenindustrie is het belangrijkste voor deze opleiding, met een werkgelegenheidsaandeel van circa $27 \%$. Ook in de sector handel is echter een belangrijk deel van de arbeidskrachten met deze opleiding werkzaam (19\%). De twee belangrijkste beroepsklassen zijn bakkers e.a. (industrieel) bakkerijpersoneel (19\%) en koks, kelners e.a. keuken en serveerpersoneel (12\%).

In tegenstelling tot de meeste andere technische opleidingen is deze opleiding redelijk ongevoelig voor conjuncturele schommelingen in de werkgelegenheid. Zeker voor schoolverlaters is dit het geval. Een negatief punt is echter wel dat schoolverlaters bij hun arbeidsmarktintrede sterk afhankelijk zijn van een beperkt aantal bedrijfsklassen en beroepen. Overigens ontstaan er reeds vrij snel in de loopbaan meer mogelijkheden om uit te wijken naar andere arbeidsmarktsegmenten.

Opvallend is dat jongeren met deze opleiding in vergelijking met de andere VBO-opleidingen erg veel verdienen. Ten opzichte van het gehele VBO technisch is het verschil gemiddeld ruim 100 gulden bruto per maand. In vergelijking met het VBO als geheel loopt het verschil zelfs op tot boven de 250 gulden. Deze momenteel gunstige positie voor deze schoolverlaters wordt nog versterkt doordat slechts een fractie van hen in hun kwalificaties wordt onderbenut. Bovendien heeft ruim $80 \%$ van de schoolverlaters direct in aansluiting op de opleiding een baan gevonden. Momenteel is het werkloosheidspercentage onder schoolverlaters $5 \%$.

De perspectieven op de arbeidsmarkt zijn voor schoolverlaters van deze opleiding echter matig. Niet alleen is de uitbreidingsvraag de komende jaren naar verwachting negatief, maar ook de vervangingsvraag is met $2,1 \%$ gemiddeld per jaar wat lager dan het gemiddelde voor het VBO technisch, ofschoon het verschil minder groot is dan men op grond van de leeftijdsverdeling zou verwachten. De verwachte arbeidsmarktinstroom van schoolverlaters bedraagt, uitgedrukt als percentage van het aantal werkenden $2,3 \%$ gemiddeld per jaar. Dit betekent dat er een overschot ontstaat van enkele honderden nieuwkomers met deze opleiding, dat kan oplopen tot wel $20 \%$ van de verwachte instroom van schoolverlaters in de periode 1993-2000.

Werkgevers zullen derhalve weinig hinder ondervinden van arbeidsmarktknelpunten bij het werven van nieuw personeel met deze opleidingsachtergrond. Ook bij een verder aantrekkende economie blijft de kans hierop klein. Deze opleiding is immers, zoals gezegd, niet erg afhankelijk van de economische ontwikkeling. Schoolverlaters van deze opleiding kunnen derhalve nauwelijks profiteren, mocht de economie zich de komende jaren gunstiger ontwikkelen dan momenteel in het basisscenario wordt voorzien. 